\title{
HEINONLINE
}

Citation: 72 Miss. L.J. 213 2002-2003

Content downloaded/printed from

HeinOnline (http://heinonline.org)

Fri Jul 27 16:12:29 2012

-- Your use of this HeinOnline PDF indicates your acceptance of HeinOnline's Terms and Conditions of the license agreement available at http://heinonline.org/HOL/License

-- The search text of this PDF is generated from uncorrected OCR text.

-- To obtain permission to use this article beyond the scope of your HeinOnline license, please use:

https://www.copyright.com/ccc/basicSearch.do?

\&operation $=$ go\&search Type $=0$

\&lastSearch $=$ simple\&all $=$ on \&titleOrStdNo $=0026-6280$

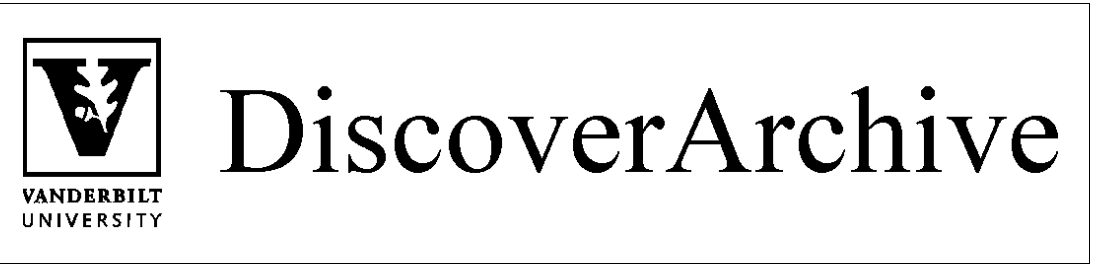

Retrieved from DiscoverArchive,

Vanderbilt University's Institutional Repository

This work was originally published in

72 Miss. L.J. 213 2002-2003 


\section{PUBLIC PRIVACY: CAMERA SURVEILLANCE OF PUBLIC PLACES AND THE RIGHT TO ANONYMITY}

\section{Christopher Slobogin ${ }^{1} \mathbb{O} 2002$}

Introduction $\ldots \ldots \ldots \ldots \ldots \ldots \ldots \ldots \ldots 214$

I. Camera Surveillance of the Public Now and in the NearFuture ......................219

A. The Surveillance Dragnet . . . . . . . . . . . 219

B. Current Legal Regulation of Public Camera Surveillance ......................233

II. The Right to Public Anonymity . . . . . . . . . . 237

A. The Impact of Losing Public Anonymity . . . . . 240

1. The Panopticon Analogy . . . . . . . . . . . 240

2. The Effects of Being Watched ......... 242

3. The Government's Use of Surveillance ...... 247

B. The Constitution and Public Camera Surveillance 252

1. Freedom of Speech and Association . . . . . . . 252

2. Freedom of Movement and Repose . . . . . . 2 258

3. The Right to Privacy . . . . . . . . . . 263

4. Freedom from Unreasonable Searches and Seizures . . . . . . . . . . . . . . . 267

C. An Empirically-Based Case for Fourth Amendment Regulation of CCTV . . . . . . . . . . . 272

1. Sources of Society's Privacy Expectations Vis-a-vis CCTV . . . . . . . . . . . . . . . 272

2. The Study . . . . . . . . . . . . . 275

3. The Relevance of Empirical Findings . . . . . 280

D. Summary $\ldots \ldots \ldots \ldots \ldots \ldots \ldots \ldots \ldots 285$

1 Stephen C. O'Connell Professor of Law, University of Florida Fredric G. Levin College of Law. The author would like to thank Tom Clancy and the National Center for Justice and the Rule of Law, University of Mississippi Lamar Law Center, for the generous support of this project and the invitation to speak at the Technology and the Fourth Amendment Symposium in April, 2002. I also thank David Fontana, Lyrissa Lidsky, Scott Sundby, and Andrew Taslitz for their comments, and David Benjamin and Ryan Cobbs for their research assistance. 
III. Impementing the Right to Public Anonymity . . . . . 286

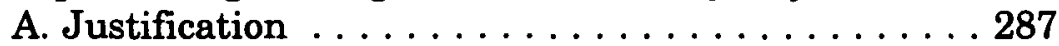

1. Justifying Camera Location . . . . . . . . . 287

2. Justifying Individualization of Surveillance . . 295

B. Execution Issues . . . . . . . . . . . . . . . . . . 297

1. Notice . . . . . . . . . . . . . . . . . . . . 297

2. Avoiding Discriminatory Surveillance . . . . . 298

3. Termination of Surveillance . . . . . . . . . . 299

C. Storage and Dissemination of Recordings . . . . 301

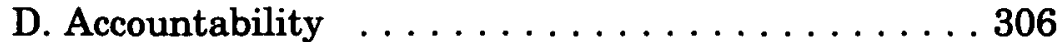

1. Watching the Watchers . . . . . . . . . . 306

2. Assuring Compliance . . . . . . . . . . . 307

3. Beyond Sanctions: Accountability Through Information . . . . . . . . . . . . . 310

IV. Concluding Comments: A Different Fourth

Amendment? . . . . . . . . . . . . . . . . . 312

\section{INTRODUCTION}

In London, police say that every worker or shopper is caught on at least 300 cameras every day. ${ }^{1}$ [In the United States] the security industry estimates that more than 2 million surveillance cameras are in use across the country. In Manhattan in 1998, volunteers counted 2,400 electronic eyes in public places used to catch everything from red-light runners at traffic intersections, shoplifters outside grocery and department stores, and drug sellers loitering near lampposts. ${ }^{2}$

There was of course no way of knowing whether you were being watched at any given moment. GEORGE ORWELL, $1984 .^{3}$

[I]f . . dragnet type law enforcement practices should eventually occur, there will be time enough then to determine

1 Alfred Lee, Big Brother is Watching You, THE STRATTS TIMES (Singapore), August 23, 2001, at 7 .

${ }^{2}$ Spencer S. Hsu, D.C. Forms Network of Surveillance, WASH. Post, Feb. 17, 2002 , at $\mathrm{C} 1$.

s at 3 (Harold Bloom ed., Chelsea House 1987)(1949). 
whether different constitutional principles may be applicable. United States v. Knotts. ${ }^{4}$

It is time to constitutionalize strictures on public surveillance. The advent of sophisticated technology that allows the government to watch, zoom in on, track, and record the activities of anyone, anywhere in public, twenty-four hours a day, demands regulation. Yet to date no meaningful constraints on this type of surveillance exist. The constant drumbeat of the "war on crime," louder than ever since the terrorist attack on September 11, has drowned out calls for greater control over technological surveillance of the streets. This article argues that the Fourth Amendment requires courts to regulate such surveillance-in particular camera surveillance of public activity-if the legislative and executive branches are unwilling to do so on their own.

The primary obstacle to this agenda is the United States Supreme Court decision in United States $v$. Knotts, ${ }^{5}$ which considered the Fourth Amendment's application to tracking a car's movements with an electronic beeper. There the Court held that "[a] person traveling in an automobile on public thoroughfares has no reasonable expectation of privacy in his movements from one place to another. ${ }^{n 6}$ Even more significantly, it concluded that the fact that such movements might be detected through use of a beeper rather than via visual surveillance "does not alter the situation." If the Fourth Amendment is not implicated by technological surveillance of a car traveling on public thoroughfares, it is unlikely to apply to enhanced surveillance of a person walking the streets.

As the portion of Knotts highlighted above indicates, however, the Court did broach a caveat to its conclusion-perhaps a tiny one, but nonetheless one that is very pertinent today. Knotts had argued that a holding that no search occurs when police track a person's car using a beeper would mean that

460 U.S. 276, 284 (1983).

460 U.S. 276 (1983).

- Knotts, at 281.

I Id. at 282 . 
"twenty-four hour surveillance of any citizen of this country will be possible, without judicial knowledge or supervision." Although the Court considered this observation irrelevant to the case at hand, where the beeper had merely been used to relocate the receptacle in which it had been placed after police lost visual contact, ${ }^{9}$ it also acknowledged that the type of "dragnet" practices conjectured by Knotts might raise constitutional issues. ${ }^{10}$

That concession is important because in many urban, and even some suburban, areas today, full-time technological surveillance of the public is the norm. ${ }^{11}$ While tracking devices comprise one aspect of this surveillance, it is cameras, positioned on buildings and telephone poles, that pose the biggest threat in this regard. The traditionally grainy video image, accessible at the time it is captured only by the camera operator, is rapidly being replaced by digital technology that produces top-quality images available in real time to police and to others at remote locations, including command centers and patrol cars. ${ }^{12}$ Digitization allows much easier long-term storage than bulky videotape, thereby increasing the potential that images will be around longer and viewed by more people, and it also makes possible identification of those captured on camera through computer-based matching programs (called "biometric" technology). ${ }^{13}$ Dragnet surveillance is upon us.

Id. at 283.

- The government had installed the beeper in a chloroform container, which an accomplice of Knotts purchased. Id. at 278. The accomplice placed the container in his car, which police followed. Id. The container was soon transferred to the car of another accomplice, which police also followed. But the driver used evasive maneuvers, and the police had to resort to the beeper signal to discover the whereabouts of the container, which was located in a cabin in which Knotts and others had constructed a drug laboratory. Id. at 278-79.

${ }^{10}$ Id. at 284.

"See infra text accompanying notes 29-32.

12 See infra text accompanying notes $20-28$. Even poor quality video can be enhanced with new technology. Elizabeth Mehren, Technology Helps Put Surveillance in Focus, L.A. TTMES, Oct. 9, 2001, at 24 (describing a company called "Salient Stills" that can create a more cohesive image out of blurry video by making a composite out of several frames).

1s See Christopher S. Milligan, Facial Recognition Technology, Video Surveillance, and Privacy, 9 S. CAL. INTERDIS. L.J. 295, 3030-08 (1999)(describing digital and biometric technology). 
The Court's unwillingness in Knotts to announce definitively that all public surveillance is unregulated by the Constitution may reflect an intuition that at some point this type of surveillance amounts to a serious infringement of "reasonable expectations of privacy," the concept that defines the scope of the Fourth Amendment. ${ }^{14}$ Yet the Court's hesitancy to push that idea any further in Knotts probably stems not only from traditional judicial parsimony, but also from its perplexity over how one can possess "privacy" in public. When one's every movement is readily observable by others, how can one expect constitutional protection of those movements?

This article answers that question from a number of perspectives, summed up in the notion that we all possess a "right to anonymity," even when in public. Continuous, repeated or recorded government surveillance of our innocent public activities that are not meant for public consumption is neither expected nor to be condoned, for it ignores the fundamental fact that we express private thoughts through conduct as well as through words. The Fourth Amendment should be construed to recognize the right to public anonymity as a part of the privacy expectations that, to use the Supreme Court's well-known phrase, "society is prepared to recognize as reasonable."15

Part I of this article sets the stage for this argument by describing some of the surveillance technology that exists and the deficiencies in the way legislatures and courts have reacted to it. Part II develops the basis for the right to public anonymity. It draws from a number of different commentators and court decisions, as well as from an empirical study that demonstrates the extent to which ordinary citizens value the ability to walk and drive the streets without having to contend with constant technological monitoring. Part III then explicates the implications of the right to anonymity, relying to a significant

${ }^{14}$ Katz v. United States, 389 U.S. 347, 360 (1967)(Harlan, J., concurring). See infra text accompanying notes 235-247.

1s This language first appeared in Harlan's concurrence in Katz. See Katz, 389 U.S. at 361. It has since found its way into several majority opinions. See, e.g., California v. Greenwood, 486 U.S. 35, 29-40 (1988); California v. Ciraolo, 476 U.S. 207, 211 (1986); United States v. Jacobsen, 466 U.S. 109, 122 (1984). 
extent on the recommendations of the American Bar Association's Standards on Technologically-Assisted Physical Surveillance, ${ }^{16}$ for which I was the Reporter.

As Part III makes clear, a determination that public surveillance must be subject to constitutional review does not necessarily mean that the usual Fourth Amendment jurisprudence-involving warrants, probable cause, and so on-applies to this particular type of government activity. I argue that the courts' role should consist of setting minimal guidelines and monitoring police decisions to assure that such surveillance is conducted in a reasonable manner. More specifically, I contend that, given its relatively unintrusive nature, most public surveillance of individuals does not require probable cause in the traditional sense. At the same time, rules regarding who is involved in the targeting decision, the execution of the police action, and post-action record-keeping and disclosure should assume much more significance here than in connection with the classic police search. While most of the details would be left up to the political process, application of the Fourth Amendment to public surveillance would guarantee that, in contrast to the current state of affairs, courts would have the opportunity to provide legislative bodies with a "constitutional road map" on an issue that is already a potent symbol of governmentcitizen interaction, and one that is likely to become more so in years to come. ${ }^{17}$

A sub-theme of this article is that Fourth Amendment jurisprudence needs to expand its focus beyond the traditional individualized suspicion model, backed by a motion for exclusion, as the primary means of protecting individual interests. Surveillance of large numbers of people cannot, and should not,

16 AMERICAN Bar Association, Standards for Crminal Justice-Electronic Survemlance (3D ED.), Section B: Technologically-Assisted Physical SuRVEILLANCE [hereafter ABA STANDARDS]. The ABA Standards were drafted by a Task Force composed of judges, lawyers, law enforcement officials and privacy experts in a series of meetings from 1995 through 1997, and were subject to comment and redrafting by both the Standards Committee and the Council of the Criminal Justice Section of the ABA, before being approved by the ABA's House of Delegates in August, 1998.

17 See infra text accompanying notes 311-15. 
be justified on a person-by-person basis. Nor is the suppression remedy likely to be an effective deterrent in this context, since at best it benefits an infinitesimally small number of people subjected to the illegal surveillance, and in any event is a poor remedial fit with the types of violations that public surveillance involves. The dissonance between public surveillance and the individualized suspicion/exclusionary rule model suggests a need for rethinking both the type of justification and the manner of implementation the Fourth Amendment requires. Part IV makes some brief observations in this regard, based on some of my previous work.

\section{Camera Surveillance of the Public Now AND IN THE NEAR-FUTURE}

The government uses cameras to watch us in all sorts of venues, ranging from private stores to public restrooms, from government-owned buildings to public streets, from traffic intersections and parking lots to detentions of motorists by state troopers. ${ }^{18}$ This article will focus on government camera surveillance of pedestrians in the public streets, as distinguished from video monitoring of building interiors and motorist stops. Thus, this article's use of the phrase "public camera surveillance" and its commonly accepted abbreviation "CCTV"-for closed circuit television-will refer only to the former type of surveillance. Even when defined in this narrow sense, public surveillance using camera technology is likely to increase exponentially in the next decade. As in other areas of technological development, the law is not likely to keep up. ${ }^{19}$

\section{A. The Surveillance Dragnet}

The future has arrived in Washington, D.C., in the wake of the terrorist attacks of September 11. Hundreds of government cameras are trained on streets, subways, school hallways, and

28 See infra text accompanying notes 29-34.

10 See Joyce W. Luk, Identifying Terrorists: Private Rights in the United States and United Kingdom, 25 HASTINGS INT'L \& COMP. L. REV. 223, 256-57 (2002)(describing reactive approach of United States to privacy violations). 
federal facilities, ${ }^{20}$ in a project that "makes Washington the first U.S. city to be able to peer across wide stretches of the city and to create a digital record of images. ${ }^{21}$ State-of-the-art cameras allow operators to take advantage of "satellite-based optics" that enable them to see in the dark, capture words on a printed page from hundreds of feet away, and peer into buildings. ${ }^{22}$ Only a few private cameras have been added into the mix at this point, but the head of the project states "I don't think there's really a limit on the feeds [the system] can take;" further, he wants "to build ... the capability to tap into not only video but databases and systems across the region," eventually moving into any number of schools, businesses and neighborhoods. ${ }^{24}$ All of this is to be accomplished through a $\$ 7,000,000$ central control facility, which can then relay the feeds to nearly 1000 squad cars. ${ }^{25}$

At present in the United States, only Washington, D.C. has such a sophisticated system. ${ }^{26}$ But many other American cities have installed forerunner versions that are far from antiquated. For instance, Newark, N.J., Tampa, Fl., Virginia Beach, Va., and Memphis, Tenn., all have cameras, ranging in number from six to seventy-two, that cover large areas of public real estate and that can rotate 360 degrees, pan and tilt, and zoom in on subjects. ${ }^{27}$ Tampa recently added several dozen cameras

${ }^{20}$ Hsu, supra note 2, at $\mathrm{C1}$.

21 Id.

${ }^{22}$ Id. See also, Editorial, Big Brother in the Capital, RockY MoUNTAIN News, Feb. 20, 2002, at 30A (noting that D.C. cameras do not produce "the blurry videos of convenience-store crimes [but] digital images from optical technology that can see in the dark and $z 00 m$ in on a page of fine print from hundreds of feet away.").

23 Hsu, supra note 2, at $\mathrm{C} 1$.

24 Jess Bravin, Washington Police to Play "I Spy," Wall St. Journal, Feb. 13, 2002, at B1, B6 (quoting Stephen J. Gaffigan, former Justice Department Director of Community Policing and head of the Washington Metropolitan Police Department camera installation project, as stating, "The next logical extension is into communities to aid our crime-fighting efforts.").

${ }^{25}$ Id.

20 Hsu, supra note 2, at C1. But it may already be behind the curve. A digital system has been developed that allows camera images to be fed to a wireless laptop operator who can control the camera and other remote devices. New Video Technology from AXCESS Inc., PR NEWSWIRE, Feb. 26, 2002.

${ }^{27}$ Marcus Nieto, Public Video Surveillance: Is It An Effective Crime Prevention 
equipped with face recognition technology that purportedly matches captured faces with criminal arrest records (although the city discontinued the program when it failed to produce any arrests). ${ }^{28}$

Many cities and towns are following suit in one way or another. A 2001 study by the International Association of Chiefs of Police found that $80 \%$ of the 207 responding American law enforcement agencies have deployed some sort of closedcircuit television and that another $10 \%$ will soon do so..$^{29}$ Much of this technology is "in-car" video designed to record police detention activities, or is placed at traffic intersections or in government buildings. ${ }^{30}$ But about half the responding agencies use cameras in "high crime areas," 25\% use them on "streets" and $15 \%$ use them in "parks." It should also be noted that some of the traffic networks, although primarily designed to photograph the license plates of speeders, can peer inside a vehicle, at areas outside the intersection, and even into homes and offices alongside the targeted thoroughfares. ${ }^{32}$

All of these cameras are owned by the government (although in some locales they are operated by "volunteers" from the community ${ }^{39}$ ). In the private sphere, camera use is even more widespread. A nationwide survey of a variety of compa-

Tool? CRB-97-005 (California Research Bureau, California State Library, June, 1997), at 14-18, available at http:/www.library.ca.gov/CRB/97/05/.

28 Lane DeGregory, Click. BEEP! Face Captured, St. Petersburg Ttmes, July 19,2001 , at 1D. See also infra note 67.

29 International Association of Chiefs of Police, Executive Brief, The Use of CCTV/Video Cameras in Law Enforcement, Executive Summary, March 2001, at 4, available at http://www.theiacp.org/documents/pdfs/Publications/UseofCCTV.pdf [hereafter IACP Brief].

so Id.

si Id.

32 M.J. Zuckerman, Chances Are, Somebody's Watching You, USA TODAY, Nov. 30,2000 (describing $\$ 40$ million surveillance center, controlling 110 remote control cameras in the suburbs of Washington, that can "peer inside a vehicle" and "easily see into the homes and offices along the interstates").

3s Nieto, supra note 27, at 21. In Anchorage, Alaska, for instance, volunteer video patrols funded by the business community and state grants train cameras on residential and commercial sections of the city. Id. In Hollywood, California, cameras are monitored by local residents and Los Angeles Guardian Angels. Id. at 20. 
nies, taken over five years ago, found that $75 \%$ use CCTV surveillance. ${ }^{34}$ That fact becomes important even if the focus is solely state action, given the above-mentioned capacity to link these cameras to government command centers.

That is precisely what has happened in Great Britain, the champion of CCTV surveillance. There are now well over 800 local public video surveillance programs in operation in the United Kingdom, ${ }^{35}$ involving between two and three million cameras, ${ }^{36}$ and creating more video images per capita than any other country in the world. ${ }^{37}$ Between 200,000 and 400,000 of these cameras monitor public areas; ${ }^{38}$ many are equipped with zoom lenses that can read the wording on a cigarette packet at 100 yards and bring nighttime images up to daylight level. ${ }^{99}$ And the installation of cameras is likely to continue unabated. Researcher Clive Norris concludes that "in the first decade of the new millennium, when average Britons leave their homes what will be remarkable is if their presence is not seen, their behavior not monitored and their movements not recorded by the omni-presence of the cameras, CCTV operators, and video recorders. ${ }^{840}$ Most of these programs are jointly operated and managed by law enforcement and the private sector. ${ }^{41}$ Almost all are linked to police stations, but quite a few are also monitored by private security guards. ${ }^{42}$ Many oth-

s4 Karen Hallberg, Nationwide Survey of Companies With Security Expenses, Cahners Publishing Company, September, 1996 (on file with author).

ss This was the estimate in 1996. Nieto, supra note 27 , at 7 .

36 See Lee, supra note 1 , at 7 (reporting that in 2001, Great Britain had installed 2 million cameras and was planning on spending another $\$ 100$ million to install thousands more).

${ }^{37}$ Nieto, supra note 27 , at 8.

38 Simon G. Davies, Re-Engineering the Right to Privacy: How Privacy Has Been Transformed from a Right to a Commodity, in TECHNologY AND PRIVACY: The NEw LANDSCAPE 150 (Phillip E. Agre \& Marc Rotenberg eds., MIT Press 1997) (estimating that 200,000 cameras cover public spaces and indicating that this figure would grow at 20 to $30 \%$ annually).

so Id.

40 Clive Norris, From Personal to Digital: CCTV, the Panopticon and the Technological Mediation of Suspicion and Social Control, in SURVEILLANCE and Social SORTING: PRIVACY Risk and Automated Discrimination 11 (David Lyon, ed. 2002).

41 Nieto, supra note 27 , at 8 .

4 Id. 
er European countries have similar systems. ${ }^{43}$

Today, these cameras are operated primarily by people. But the camera systems of the (not-so-distant) future will be much more automated. Motion detection systems will be able to discern when movements are out of the "ordinary" and then alert human assessors, who are thereby spared sifting through mountains of data. ${ }^{44}$ License plate recognition systems will be able to identify those cars that enter unauthorized areas or that move in the wrong direction. ${ }^{45}$ Facial recognition systems, more sophisticated than the one used in Tampa, will trigger a signal when people with criminal records, outstanding warrants, or inappropriate authorization are spotted. ${ }^{46}$ Eventually cameras will even be equipped with "see-through" technology that can detect when an individual is carrying a gun. ${ }^{47}$

This huge investment in CCTV technology here and abroad is based on two premises. The first assumption, of course, is that it enhances public safety. The second is that it does so less expensively than any equally effective alternative. Both premises are subject to some doubt.

Reports abound of prodigious camera-induced drops in street crimes, in the 50 to $70 \%$ range. ${ }^{48}$ But these accounts are of questionable accuracy (at least those that describe crime

4) Id. at 9-10 (describing CCTV programs in Canada, France, Ireland, Spain, Monaco, Russia, Italy, China, Iran and Iraq).

4 Clive NorRIs \& Gary ARMstrong, The MaXtmum SuRvemlance Society: THE RISE OF CCTV 212-14 (1999)(describing "intelligent scene monitoring").

${ }^{45}$ Id. at 214-16 (describing "automatic licence plate identification"). This system is already in use in London. See id.

46 Id. at 216-19 (describing "digital facial recognition systems").

17 See David Harris, Superman's X-Ray Vision and the Fourth Amendment:

The New Gun Detection Technology, 69 TEMP. L. $\quad$ REv. $1, \quad 7-8$ n.38 (1996)(describing this technology).

t8 See Lee, supra note 1 (reporting British Home Office figures showing a 63\% decline in crime rates in areas where cameras have been installed); Nick Taylor, Closed Circuit Television: The British Experience, 1999 Stan. TECH. L. REv. I 12 (reporting British police claims that car thefts in King's Lynn were reduced by 91\%, and general crime in Bedford and Swansea was reduced by $55 \%$ and $51 \%$, respectively); Emelyn Cruz, Video Cameras Shooting Down Some Crime Rates, THE SeATTLE Ttmes, July 28, 1996 at B-1 (in Tacoma after cameras were installed, crimes such as assaults, trespassing, prostitution and vandalism dropped from 244 reported incidents in 1993 to 87 in 1994, and 125 in 1995). 
reduction due to street-based $\mathrm{CCTV}^{49}$ ). A recent commentary on the reports about the United Kingdom's CCTV system describes the glowing statistics as "post hoc shoestring efforts by the untrained and self-interested practitioner. ${ }^{\$ 50}$ More neutral analysis of the efficacy of public surveillance paints a different picture. A meta-review of thirteen of the better-conducted studies carried out in that country through 2000 concluded that "the criminological evidence as to CCTV's effectiveness in reducing crime does not support the almost exponential increase in cameras on British streets as a crime prevention measure. ${ }^{\text {} 51}$ Another recently concluded meta-analysis of the twenty-two most carefully conducted studies in the United Kingdom and North America indicated that while half of the studies found a "desirable effect on crime," five found an "undesirable" effect, and six found no effect or an uncertain effect on crime;

49 Taylor, supra note 48, at II 13-14. The success of CCTV in stores, transportation centers and the like is better documented. For instance, London's Gatwick Airport saw a $78 \%$ drop in crime in its car parks after cameras were installed, and Chesterfield railway station a drop in vehicle crime of $96 \%$. Stephen Wright, Police Release CCTV Images of BBC Presenter, DAILY MAIl (London), May 3, 1999, at 2. But even here the effectiveness of CCTV is not proven beyond doubt. See Emma Short \& Jason Ditton, Does CCTV Affect Crime?, 2 CCTV TODAY, Mar. 1995, at 11 (1995)(the results of independent and competently conducted evaluations of CCTV systems installed in car parks, buses, housing estates, football stadia and the underground are "fairly contradictory regarding the effectiveness of CCTV as a crime prevention method," with some showing no effect, others showing high levels of displacement rather than overall reduction, and others showing clear reductions).

so Ray Pawson \& Nick Tilley, What Works in Evaluation Research? 34 BRTT J. CRnminology 291, 294 (1994); see also, Taylor, supra note 48, at I13 (stating that "the vast number of evaluation schemes that have been carried out to date have been undertaken by those with an interest in promoting the cameras and have been technically inadequate").

s1 Clive Norris, Remarks at a Conference of Experts-Video Surveillance: A Crime Prevention Instrument in European Comparison 32 (Feb. 22-24, 2001)(manuscript available at Georg-August University, Gottingen, Germany and from author). Another ironic development is that pictures of crime, captured on CCTV, may actually make people feel less safe and less willing to frequent the targeted areas. Jason Ditton, Glasgow City's Cameras-Hype or Help?, ScoTTISH CENTER FOR CRIMINOLOGY, available at http:www.scotcrime.u-net.com/news1.htm (reporting that, when a large sample of people was interviewed one year after Glasgow installed cameras, "most didn't feel any safer and more said they would avoid the city centre, and speculating that the publicity from the crimes caught on camera was partly to blame). 
ultimately, "the average overall reduction in crime was a rather small four per cent."

One example of such research comes from Glasgow, one of the first major cities to adopt CCTV. There, a three-year study conducted by criminologists found that although crime was reduced in "certain categories, ... there was no evidence to suggest that the cameras had reduced crime overall," and "[ $t]$ he cameras appeared to have little effect on clear up rates for crimes and offences. ${ }^{953}$ Anecdotal statistics from the more recent past are equally disappointing. In London, where cameras abound, even street robberies-the crime CCTV is supposed to be best at deterring-increased in $2002 .^{54}$ In Sydney, Australia, a relatively new camera system produced only one arrest every 160 days. $^{55}$

American cities have had similar experiences. Early systems set up in Hoboken, N.J., Mount Vernon, N.Y., Miami, Fl., Charleston, S.C., and Detroit, Mich., were discontinued because they were not cost effective. ${ }^{56}$ Cameras in Times Square were dismantled after producing fewer than ten arrests in twentytwo months. ${ }^{57}$ These failures might be attributed, at least in part, to the primitiveness of the technology used. However, Oakland, Calif., recently ended its three-year experiment using high-definition cameras-able to read a flyer hundreds of yards

32 Brandon C. Welsh \& David P. Farrington, Crime Prevention Effects of Closed Circuit Television: A Systematic Review 41 (August, 2002)(Home Office Research Study 252, on file with author). This study also noted that all five North American CCTV studies showed no evidence of a desirable effect on crime. Id. at $\mathbf{4 2 .}$

${ }^{63}$ See Jason Ditton, The Effect of Closed Circuit Television Cameras on Recorded Crime Rates and Public Concern About Crime in Glasgow, ScOTTISH CENTER FOR CRIMINOLOGY, available at http:/www.scotcrim.u-net.com/research.htm.

s4 UPI, "Spy" Cameras us. Villains in Britain (Mar. 8, 2002), available at http:www.gyre.org/news/cache/1885. This article also notes that in London's Newham district, with 300 cameras, street crime in 2001 increased by one-fifth over the previous year, and car thefts increased by $3.6 \%$.

so Bruce Andrews, Here's Looking at You, SYdNEY MORnIng Herald, Dec. 26, 2001, at 16, available at 2001 WL 31626512.

56 Quentin Burrows, Scowl Because You're on Candid Camera: Privacy and Video Surveillance, 31 VAL. U. L. REV. 1079, 1103 (1997).

${ }^{67}$ Id. See also Maureen O'Donnell, Cameras Around Every Corner, ChICAGo Sun-TnMES, Feb.18, 1996, at 2, available at 1996 WL 6732224. 
away and a license plate more than a mile away-because it had no "conclusive way to establish that the presence of video surveillance cameras resulted in the prevention or reduction of crime. ${ }^{m 8}$

There are many reasons why cameras might not be effective at reducing crime in the areas on which they are trained. To understand why, consider the three ways cameras can, in theory, be useful: (1) they might help spot incipient crime that can be prevented, or at least solved, through immediate action; (2) they might create a record of crime that can be used in identifying and convicting perpetrators at some later point in time; and (3) they might deter crime. In each of these three areas, obstacles to smooth functioning exist.

Cameras' ability to help immediately nab potential or actual perpetrators is circumscribed by a number of factors. Camera operators may not observe crime in the targeted area because the cameras have been destroyed or tampered with, ${ }^{59}$ bad lighting or obstacles prevent good viewing (e.g., drug transactions carried out between cars), ${ }^{60}$ or the operator is distract$\mathrm{ed}^{61}$ or unable to recognize what is happening in ambiguous

68 Cameras in the District of Columbia: Before the House Comm. on Gov. Reforms, 107th Cong. 3 (2002)(statement of Johnny Barnes, Executive Director, ACLU of National Capital Area)(quoting Report of Joseph Samuels, Jr., Chief of Police, Oakland Police Department to Oakland City Council), available at http://www.aclu.org/congress/1032202a.html.

${ }^{59}$ Liz Kay, Camera Becomes New Weapon in War on Graffiti Vandalism: Officials Say the Motor Sensing Device Deters Taggers, but Critics Say It Just Pushes the Problem to New Location, L.A. Times, Dec. 24, 2001, at B4, available at 2001 WL 28939163 (quoting a detective saying that gang members "rip [the cameras] off. They break them, they turn them, they shoot them up. It's more of a game for them. If they are going to do their illegal activity, they are going to make sure [the cameras] are not working.").

so See UPI, supra note 54 (quoting one official who said "[t]here are hundreds of thousands of nooks and crannies left" that cameras cannot view, and noting that some criminals "are targeting luxury cars on the move so that any view the cameras gets of them is fleeting at best" and that "[o]thers conceal their street muggings by grabbing their targets in a clinch that, on CCTV, looks like nothing more than a romantic hug.").

61 According to Norris \& Armstrong:

It is not possible for one or even two operatives to continuously monitor the output of a twenty-camera system and, of course, as soon as they selectively focus on one incident, other screens are going unmonitored. This is exacerbated by the inherent boredom of watching dozens of 
situations. ${ }^{62}$ If operators do see something suspicious, their distance from the scene sometimes makes them overcautious in concluding a crime is occurring. ${ }^{63}$ And even when incipient crime is clearly identified, police will not necessarily be deployed. A dearth of sufficiently proximate officers (created in part by the belief that fewer police are needed when cameras are present ${ }^{64}$ ), lack of or poor communication between the control room and those in the street, ${ }^{65}$ and even police fear of being caught on camera and having one's actions misinterpreted can limit law enforcement response. ${ }^{66}$ All of these problems have their analogues in systems that are more fully automated. Alarms may not sound because of technological flaws, ${ }^{67}$ or de-

screens and the inattentiveness that results. But even the most attentive of operators are swamped by the volume of information. For instance . . . a medium-sized 24-hour city centre system with twenty cameras Igenerates] a quite staggering 43 million "pictures" per day.

NORRIS \& ARMSTRONG, supra note 44, at 211.

See generally Remarks of Thomas Coty (Manager of the National Institute of Justice Video Sensor and Processing Program), at Meeting of the Security Industry Association and International Association of Chiefs of Police, at 39 (Apr. 17, 2002)(transcript available at http://www.securitygateway.com/E/E3_5.html thereafter SIA and LACP Meeting](stating "[O]ne of the problems we see in CCTV is that if it's being operator maintained or monitored, after about twenty minutes the eyes start to glaze and it's difficult to keep monitoring the monitor."). Id.

so Norris, supra note 40 , at 19 (CCTV operatives . . . are . . . always accountable to justify the request for intervention and, unlike the patrol officer, do not have the benefit of hindsight, [which] serves to limit requests for deployment to only those events that can generate the most concrete and strongest justifications."). Note, however, that operators can be overaggressive in singling out certain types of suspects. See infra text accompanying notes 147-57.

a See Taylor, supra note 48, at 932 (noting that soon after cameras were introduced in Bingley, Yorkshire, the number of officers based in town was reduced from twenty-four to three).

${ }^{60}$ Norris \& Armstrong, supra note 44, at 166 (concluding that the reason many suspects reported by a field agent to the camera operator were never located by the operator was that "location is often imprecise and descriptions are too vague to significantly differentiate a suspect from the crowd").

68 Id, at 188-96 (describing implications of fact that "the practice of street policing, which traditionally enjoyed low visibility from managerial scrutiny is now potentially subject to a far more intrusive supervisory gaze").

67 Tampa abruptly suspended its face recognition program after less than two months, apparently because the system failed to identify correctly a single face in its database of suspects, and thus did not result in any arrests. The Failure of Facial Recognition Technology in Tampa, Florida (ACLU Special Report), January 3,2002 , at 1 (on file with author). This report also describes several studies indi- 
ployments may not occur because of human ones.

Attempts to memorialize the crime and the perpetrator on tape can also run into difficulty. Sometimes tapes are destroyed before authorities realize they may be helpful in solving crime. ${ }^{68}$ Nor does retention of the tapes guarantee identification. Recordings are sometimes of poor quality ${ }^{69}$ (although, as noted earlier, digitalization has gone a long way toward rectifying this problem), images caught on tape are always subject to interpretation (think of the Rodney King video ${ }^{70}$ ), and perpetrators are hard to identify even with good images. ${ }^{71}$ Even if tapes are preserved and the human error factor is assumed away, obtaining the relevant frames can literally consume days of effort by the police. ${ }^{72}$

Finally, cameras cannot be effective deterrents if their presence is not made known to potential perpetrators, which apparently is often the case. ${ }^{73}$ And even when the cameras'

cating that, to date, the technology has not been very effective. Id. at 3 .

Bs See generally Remarks of Stephen McMahon (Central District Commander for Baltimore City), SIA \& IACP Meeting, supra note 62, at 39 (noting that tapes are destroyed after ninety-six hours and that tapes of a few "non-crime related" incidents were therefore lost).

${ }_{69}$ Kay, supra note 59 , at 4 (stating that, with respect to one system, Los Angeles "[o]fficials have not made any arrests based on photos taken by the camera at any location [because] pictures are seldom clear enough to identify the person responsible for the graffiti."); Zuckerman, supra note 32, at 1A (noting that tape at ATM machine had been used so many times that image of person using a murder victim's card was too obscured for identification purposes).

70 Although the tape clearly showed officers beating King, it did not capture the high speed chase and King's aggressive actions prior to the beating. See GEORGE P. FLETCHER, WITH JUSTICE FOR SOME 38-41 (1996)(recounting the behavior of King and the officers prior to the videotaping); see also The 1991 Rodney King Police Brutality Case and the Los Angeles Riots, at http:/www.crimsonbird. com/history/rodneyking.html (discussing police chase and subsequent beating).

${ }^{11}$ Zoe Henderson et al., Matching the Faces of Robbers Captured on Video, 15 APPLIED COGNITIVE PSYCHOLOGY 445 (2001)(reporting research finding that matching unfamiliar faces from both high- and low-quality CCTV with photographs is "highly error-prone").

73 Norris, supra note 40 , at 17 (recounting one case which involved 4000-man hours of video analysis), \& at 35 (noting that multiplexing cameras, a common efficiency procedure that takes only a few frames per second from each of many cameras, produces a loss of information that can make incident spotting difficult); cf. State v. Bonnell, 856 P.2d 1265, 1271 (Haw. 1993)(describing accumulation of fifty videotapes with twelve hundred hours of footage, containing just one minute of conduct that might have reflected gambling activity).

\footnotetext{
73 Jason Ditton \& Emma Short, Evaluating Scotland's First Town Centre
} 
presence is conspicuous, certain types of offenders are too preoccupied or dense to notice, or are oblivious (as with rowdy revelers) ${ }^{74}$ or uncaring (as with nighttime prowlers who wear masks, wigs, or other disguises). ${ }^{75}$ A 1995 study reported that criminals believe the presence of cameras is the least of their concerns in considering whether to rob businesses. ${ }^{76}$ Also of note is that the presence of cameras may simultaneously reduce surveillance by citizens, who assume that the cameras will do the job. ${ }^{77}$

Findings that crime has dropped in areas exposed to cameras must also be tempered by two facts. In some studies, part of the crime reduction was undoubtedly due to other factors, including additional crime control measures undertaken at the time the cameras were installed and decreasing crime rates overall. ${ }^{78}$ Second, many of these studies did not take into ac-

CCTV Scheme, in Survemlance, Closed Circutt Television and Social ConTROL (Clive Norris et al., eds., 1998)(after a year of cameras in Glasgow's town center, "only between a quarter and a third of the ambulatory population were even aware of their existence"); John Naughton, Video Eyes Are Everywhere: "Big Brother" in Britain, THE OBSERVER (U.K.), Nov. 13, 1994, at 13 (noting that most people in Britain are unaware of the extent to which camera surveillance occurs).

74 Chris Arnot, We've All Been Framed: It's Not Big Brother Who's Watching Over Us-It's All His Young Siblings, Monitoring Our Every Move in Public (and Many Private) Places, THE GuARDIAN (UK), Dec. 13, 1999 (stating "[w]hen young men have had between five and 10 pints of lager and their honour is challenged, the presence of a camera makes no difference.").

${ }_{75}$ See also, Emma Short \& Jason Ditton, Seen and Now Heard: Talking to the Targets of Open Street CCTV, 38 BRIT. J. CRIMINOLOGY 404, 418-20 (1998)(noting that eight of thirty criminals interviewed claimed CCTV cameras had no effect on their pattern of offending, with others saying they committed offenses outside of camera range, and a "small minority" saying they gave up offending altogether).

${ }^{76}$ See Nieto, supra note 27, at 11 (discussing the results of a study undertaken by Rosemary Erickson of the Athena Research Corp.).

77 Stephen Graham, Towards the Fifth Utility? On the Extension and Normalisation of Public CCTV, in SuRveILAANCE, Closed CIRCuIt TElevision aNd SOCLAL CONTROL, supra note 73, at 89, 106 ("Anecdotal evidence has already emerged that the Newcastle West End scheme has significantly cut phone calls to the police, because local residents assume that the CCTV system will have spotted any event, anywhere, and at any time.").

78 For instance, Tacoma, Wash., one of the few American cities that has kept crime statistics and reported significant reductions as a result of CCTV, see supra note 48, added street lights, removed graffiti and cleaned up vacant lots at the same time it installed cameras. Burrows, supra note 56, at 1124 n.361. In Wash- 
count the possible "displacement" effect of the cameras, despite the likelihood that any crime that surveillance does deter is simply pushed into an area that does not have cameras. ${ }^{79}$

These observations should not lead to the conclusion that public video surveillance has little or no impact on crime. Although law enforcement statistics are probably inflated (on those few occasions when they exist ${ }^{80}$, it must be acknowledged that even more careful, privately conducted studies indicate that some cities experience a noticeable reduction in offense rates after camera installation. For instance, the town center of Airdrie, Scotland experienced a 21\% drop in crime over the two year period after cameras were set up, with no obvious evidence of displacement, and after factoring out other explanatory variables such as a drop in overall crime rates. ${ }^{81}$

ington, D.C., a crime cleanup on Rhode Island Avenue was "jumpstarted by the camera but it then was followed up with a lot of other action." John Thompson (Lieutenant Colonel in United States Army), SIA \& IACP Meeting, supra note 62, at 12; see also, Ben Brown, Closed Circuit Television in Town Centres: Three Case Studies, 68 POLICE RES. SERIES 37 (1995)(stating that in Birmingham efforts were made at "pedestrianisation" of key areas of the city center at the same time cameras were installed), available at http://www.homeoffice.gov.uk/rds/orgpdfs/ fcdps68.pdf); Norris, supra note 51, at 16 ("the rapid growth of the number of CCTV systems [in the United Kingdom] (between 1993 and 1997) occurred at precisely the same time as the only sustained fall in recorded crime since the $\left.1950 \mathrm{~s}^{\prime \prime}\right)$. The latter paper recounts a number of other reasons reported crime reductions may not be accurate or not attributable to CCTV.

${ }^{79}$ See David Skinns, Crime Reduction, Diffusion and Displacement: Evaluating the Effectiveness of CCTV, in SuRveIllance, Closed Circuit Television and SOCIAL CONTROL, supra note 73 , at 185 (noting that although the town center experienced a $16 \%$ reduction in crime after camera installation, crime in the surrounding townships jumped by $31 \%$, so that overall reduction was only $6 \%$ ); Brown, supra note 78, at 35 ("Since the installation of cameras, the incidence of [street robbery, theft from the person and theft from a motor vehicle] in areas surrounding zone $A$ has increased sharply, and by the end of the study period, the number of offences per month is over three times as high as when the cameras were installed."); Chris Sarno, The Impact of Closed Circuit Television on Crime in Sutton Town Centre, in Towards a SAFER SUTTON? CCTV ONE YEAR ON (Marjorie Bulos \& Doug Grant eds., 1996)(reporting that after camera installation street thefts declined by $7 \%$, but thefts inside commercial premises increased by $30 \%$ ).

so IACP Brief, supra note 29, at 5 (96\% of the U.S. agencies surveyed by the IACP "do not incorporate measurement systems of any kind" to determine the effect of CCTV on crime rates).

${ }^{81}$ Emma Short \& Jason Ditton, Does Closed Circuit Television Prevent Crime? An Evaluation of the Use of CCTV Surveillance Cameras in Airdrie Town Center, 
Newscastle experienced significant drops in particular crimes: $35 \%$ for criminal damage, $50 \%$ for motor vehicle theft, and $56 \%$ for burglary, compared to $25 \%, 39 \%$ and $39 \%$ reductions for the same crimes in the control areas. ${ }^{82}$ A third United Kingdom study found a $25 \%$ drop in crime sustained over a two-year period, with no displacement effects. ${ }^{83}$ Although these figures are significantly lower than initial law enforcement claims, ${ }^{84}$ they are nonetheless impressive. ${ }^{85}$

When all the data are looked at closely, a fair conclusion is that well-positioned, sophisticated cameras, run by competent staff, might be able to reduce some types of street crime, particularly theft, by 10 to $25 \%$ in "high crime areas," compared to similar public areas that have no cameras, with only a small displacement effect. ${ }^{86}$ The second question that must be answered by careful policymakers is whether this reduction is cost-effective. Could other alternatives, such as more patrols, better lighting and greater community participation in law enforcement, achieve equal or better results at less cost?

I will not try to answer that question here. Some information about the cost of CCTV can provide a useful starting point,

The ScotTish OfFICE CENTRAL REsearch UNIT (1995), available at http://www.scotland.gov.uk/cur/resfinds/crf08-00.htm.

82 See Brown, supra note 78 , at 17 . Brown also notes, however, that the decline in vehicle thefts in the CCTV area "appears to fade after 8 months and the number of thefts of vehicles rises sharply." Id. at 20.

ss Rachel Armitage et al., Burnley CCTV Evaluation, in SURvenLANCE of Public Space: CCTV, Street Lighting and Crime Prevention (Kate Painter \& Nick Tilley eds., 1999).

44 Arnot, supra note 74 (noting that law enforcement claimed a $74 \%$ crime drop in Airdrie).

Bs But see Norris, supra note 51, at 26-27 (noting that a number of other well-done studies obtained "mixed results" compared to these "unequivocal success stories"). In fact, several studies showed that cameras had no overall impact on crime. Id.

s6 Although not based on controlled studies, statements by American police officials are consistent with this conclusion. Remarks of Stephen McMahon, supra note 68, at 4 (noting reductions of 18 and $25 \%$ in first two years of CCTV program in Baltimore); Remarks of Joseph Dunne (Chief of Housing Police, New York City), SIA \& IACP Meeting, supra note 62, at 21 (noting reduction of 25\% in first 6 months of camera use in New York housing projects). But see supra note 52 (describing meta-study which concluded that U.S. studies have consistently found that CCTV does not reduce crime). 
however. In the United Kingdom, a number of local authorities have yearly operating budgets of well over $\$ 500,000$ for camera systems that cover downtown areas. ${ }^{87}$ The annual budget of each of the several 100-camera systems in New York City housing projects is approximately $\$ 850,000$ just for staffing (i.e., not including the upfront costs of the cameras, their maintenance, new tapes, tape storage, and associated expenditures). ${ }^{88}$

Whether equally effective alternatives would be cheaper is harder to calculate. But it can be noted that even a relatively successful CCTV system may not "pay" for itself. One study indicated that good CCTV systems can make significant dents in shoplifting, but that the value of merchandise retained would not equal expenditures on such a system for nearly five years; ${ }^{89}$ as one researcher noted, "it might be more rational to just accept the losses. ${ }^{.90}$ Where violent crime is concerned that kind of reasoning is less palatable, and expensive surveillance systems might be endorsed if even just a few such crimes will be prevented or detected. ${ }^{11}$ Unfortunately, however, violent crimes are probably the most difficult offenses for cameras to prevent or deter, given their often spontaneous nature. ${ }^{92}$

${ }^{87}$ G. Wade, Funding CCTV: The Story So Far, 7 CCTV TODAY (1998), at 28 (stating that several local townships are "dealing with operating budgets in excess of $£ 500,000$ per year").

${ }^{88}$ Remarks of Joseph Dunne, supra note 86, at 22.

${ }^{89}$ Norris, supra note 51 , at 23 (describing a study by A. Beck \& A. Willis, Crime and Security: Managing the Risk to Safe Shopping (1995)).

${ }^{\infty}$ Id.

o1 See Davies, supra note 38, at 150 (quoting a Home Office spokesman who, in commenting on the potential of CCTV, stated "if this all saves just one life, it's worth it."). Widespread CCTV could also help apprehend individuals like the sniper who recently terrorized Washington, D.C., although such individuals would probably be adept at avoiding overtly positioned cameras.

92 Vaseekaran Sivarajasingam \& Jonathan P. Shepherd, Effect of Closed Circuit TV on Urban Violence, 16 J. ACCIDENT \& EMERG. MED. 255 (1999)(finding in a study of three Welsh cities "an overall reduction in town/city centre violence... of $1 \%$ in the 2 years after closed-circuit TV installation," which the authors concluded meant that CCTV "had no obvious influence on levels of assaults," a finding they said was consistent with the British Crime Survey finding of "no overall change" in rates of urban violence following the installation of public surveillance devices); Norris \& Armstrong, supra note 44, at 166-67 (finding that although $38 \%$ of the 45 deployments they witnessed were for violent action, most of them were fist fights and none involved death or required an ambulance). 
In sum, it is not clear that public surveillance using cameras is always a worthwhile investment from a public safety perspective. That conclusion is unlikely to slow the continued proliferation of such surveillance, however. "Common sense" judgments, which view the efficacy of cameras systems as a foregone conclusion, are likely to dominate any debate on the matter. ${ }^{93}$ Politicians will continue to point to cameras as a "silver bullet" method of crime prevention. ${ }^{94}$ Recent terrorist attacks will only add to the pressure to provide protection through surveillance. ${ }^{95}$ Although, as noted above, some cities have terminated CCTV programs that have failed to reduce crime, there is also the possibility that once the newer, more expensive systems are set up, inertia will prevent their disassembly even in the face of proven ineffectiveness. The primary question is not whether such systems will be installed or maintained, but whether and how their use will be regulated.

\section{B. Current Legal Regulation of Public Camera Surveillance}

Meaningful legal strictures on government use of public surveillance cameras in Great Britain, Canada, and the United States are non-existent. Great Britain's Code of Practice sets out operating standards "but has no mechanism for accountability or enforcement. ${ }^{\text {"96 }}$ Similarly, while governments in On-

93 Burrows, supra note 56, at 1106 (quoting a property owner who was a catalyst in implementing a CCTV system in Los Angeles as stating "Ly]ou can't commit crimes if you know Big Brother is watching you.").

of Davies' comments about government attitudes in the United Kingdom are instructive:

The government has placed video surveillance at the center of its lawand-order policy. . . . CCTV is quickly becoming an integral part of crimecontrol policy, social control theory, and "community consciousness." It is widely viewed as a primary solution for urban dysfunction. It is no exaggeration to conclude that the technology has had more of an impact on the evolution of law enforcement policy than just about any other technology initiative in the past two decades.

Davies, supra note 38, at 151.

${ }^{86}$ Lisa Guernsey, Living Under an Electronic Eye, N.Y. TmMss, Sept. 27, 2001, at G1, col. 5 (describing poll conducted after September 11, 2001, that showed increased public support for giving up "some personal freedoms in order to make the country safe from terrorist attacks," and that showed increased support for governmental monitoring of e-mail and phone conversations on a regular basis).

${ }^{\circ}$ Davies, supra note 38 , at 152; see also, Taylor, supra note 48 , at 95 \& 
tario, British Columbia, and Alberta, Canada, have adopted very extensive guidelines governing camera and tape use, storage, training, and the like-all of which are framed in terms of what governments "must" or "should" do-ultimately they are merely precatory; no administrative, civil or criminal sanctions attach if they are breached..$^{97}$ A few American cities have adopted "guidelines" as well, again none of them enforceable." In a recent meeting of the International Association of Police Chiefs, relatively comprehensive model rules were drafted, but the premise of the meeting was that "voluntary guidelines" are sufficient. ${ }^{99}$

n.52 (stating that "the use of public space visual surveillance in Britain remains largely outside of the law," although noting that storage of surveillance results may be covered by statute); A. Michael Froomkin, The Death of Privacy?, 52 STAN. L. REv. 1461, 1539 (2000)("The world leader in the deployment of surveillance cameras, the United Kingdom, has some of the strictest data protection rules in the world, but this has done little or nothing to slow the cameras' spread.).

97 Guidelines for Using Video Survenlance Cameras in PUblic Places (2001), available at http://www.ipc.on.ca/english/pubpres/papers/video-gd.pdf. These guidelines were promulgated by the Information and Privacy Commissioner, Ontario, Canada. The introduction to the Guidelines state that "[t]hese Guidelines build on those developed by" the governments of British Columbia and Alberta, Canada. Id. For the most part, they are a good model for CCTV regulation. Further, in section 8 , they provide for "regular audits" to "address the institution's compliance with the operational policies and procedures." Id. They also state that "[a]n external body may be retained in order to perform the audit" and that "[a]ny deficiencies or concerns identified by the audit must be addressed immediately." Id. But there are no provisions regarding sanctions if the audit reveals misconduct.

Remarks of John Firman (Director of Research for the International Association of Chiefs of Police), SIA \& IACP Meeting, supra note 62, at 32 ("the massive amount of policies, procedures and guidelines in place with eighteen thousand law enforcement agencies all over the country are voluntary"). The bigger problem is the complete lack of rules in many jurisdictions. The IACP survey indicated that $53 \%$ of the respondents had no formal written guidelines or policies governing use of CCTV. IACP Brief, supra note 26, at 9.

o9 See Gumelines for Closed Circuit Television (CCTV) for PUB. Safety AND Community Policing (Proposed Official Draft No. 9, 2000), available at http://www.securitygateway.com/E/E3_2.html (calling for an internal "system of review or audit"); Remarks of Lessing Gold (Moderator), SIA \& IACP Meeting, supra note 62, at 19 (describing framework for developing IACP Guidelines on CCTV); see also Remarks of Barry Steinhardt (Associate Director and Chair of Cyber-Liberties Task Force, ACLU), SIA \& IACP Meeting, supra note 62, at 33 ("Voluntary guidelines are cold comfort to someone who has their rights violated 
The one American statute that deals specifically with video surveillance of public activities comes from Arizona. ${ }^{100}$ That law makes it a misdemeanor for a person to use video "surveillance" in a public place without prominently and legibly posting notice that such surveillance is taking place. ${ }^{101}$ The statute exempts journalists from this prohibition, but not law enforcement. ${ }^{102}$ As the language indicates, however, if notice of the surveillance is posted then the law is not violated, and no other strictures are placed on the operation of the cameras or on access to surveillance results. ${ }^{103}$ Apparently no other states or municipalities have adopted anything similar to this relatively undemanding law. ${ }^{104}$

A principal reason for the virtually unanimous resistance to a tougher stance on public video surveillance in the United States is the assumption that courts are not likely to find unregulated public camera viewing inimical to the Constitution or any other established body of law. Video surveillance of the home interior and similar areas is probably governed by the

and who wants to go to court to have those rights enforced.").

100 ARIZ. REV. STAT. §§ 13-3019 (2001)

101 Id.

${ }^{102}$ Id. It also exempts surveillance of people who have given written consent to the surveillance, but not, somewhat surprisingly, presumptively consensual video of activities such as family gatherings and the like when conducted by people who are involved in the gathering. Id.

103 Id.

104 Remarks of Thomas Lambert (Attorney), SIA \& IACP Meeting, supra note 62 , at 50 ("there really isn't currently any statute that expressly deals with CCTV use"). In 2002, the Virginia legislature considered a statute that would require a judicial order for the use of facial recognition technology outside of correctional institutions. See HB 454 Gen. Assem., Reg. Sess. (Va. 2002)(seeking to add $\S \S 19.2-70.4$ et seq. to the Virginia statutes). California law prohibits attempts to capture the image of a person "engaging in a personal or familial activity under circumstances in which the plaintiff had a reasonable expectation of privacy, through the use of a visual or auditory enhancing device, regardless of whether there is a physical trespass, if this image, sound recording, or other physical impression could not have been achieved without a trespass unless the visual or auditory enhancing device used was use of cameras to record a person." CAL. Crv. CODE. \& 1708.8(b) (1999). A number of other states have similar laws, but "[o]verhelmingly, ... this protection does not extend to the public space." Lance E. Rothenberg, Re-Thinking Privacy: Peeping Toms, Video Voyeurs, and the Failure of Criminal Law to Recognize a Reasonable Expectation of Privacy in the Public Space, 48 AM. U. L. REV. 1127, 1145 (2000). 
Fourth Amendment. ${ }^{105}$ But all courts that have considered application of the Fourth Amendment to cameras aimed at public streets or other areas frequented by a large number of people have declared that such surveillance is not a search, on the ground that any expectation of privacy one might have in these areas is unreasonable. ${ }^{106} \mathrm{~A}$ few courts have noted that particularly intrusive public surveillance might implicate the Fourth Amendment, but all have shied away from so holding. ${ }^{107}$ Similarly, some courts have held that Title III, which

105 See, e.g., United States v. Mesa-Rincon, 911 F.2d 1433, 1437 (10th Cir. 1990)(holding "the general fourth amendment requirements are still applicable to video surveillance" of the home); Ricks v. State, 537 A.2d 612, 620 (Md. 1988)(discussing applicability of Fourth Amendment to video surveillance of the home). Cf. Kyllo v. United States, 533 U.S. 27 (2001)(holding that use of a thermal imaging device to discern the contents of the home is a Fourth Amendment search). But see infra text accompanying notes 233-34.

106 See, e.g., United States v. Jackson, 213 F.3 1269, 1281 (10th Cir. 2000)(covert video cameras on a telephone pole overlooking outside of defendants' residences); U.S. v. Reed, No. 99-16439, 2000 U.S. App. LEXIS 22684, *8 (9th Cir. 2000)(covert video of shared hallway of an apartment complex); United States v. McIver, 186 F.3d 1119 (9th Cir. 1999) (unmanned video in national forest); Rodriguez v. United States, 878 F.Supp. 20, 24 (S.D.N.Y.1995)(covert video surveillance of activities on public street); Vermont v. Costin, 720 A.2d 866, 867 (Vt. 1998)(covert video of private but unposted fields 150 yards from defendant's house); State v. Augafa, 992 P.2d 723, 732-33 (Haw. Ct. App. 1999)(video of defendant on public sidewalk using camera on a pole nearby); McCray v. State, 581 A.2d 45, 47-48 (Md. App. 1990)(covert video of defendant crossing the street). See also, Vega-Rodriguez v. Puerto Rico Tel. Co. 110 F.3d 174, 181 (1st Cir. 1997)(covert video of workers in an "open and undifferentiated work area"); Michigan v. Lynch, 179 Mich. App. 63, 445 N.W.2d 803 (1989)(covert video of common area of restroom); Young v. State, 849 P.2d 336, 340-42 (Nev. 1993)(covert video of doorless bathroom stall); Sponick v. City of Detroit Police Dept., 49 Mich.App. 162, 211 N.W.2d 674 (1973)(covert video of defendant talking in public bar); State v. Bailey, 2001 WL 1739445, *2-3 (Del. Super. Ct. 2001) (surveillance of commercial storage facility). Even video surveillance of the curtilage may not implicate the Fourth Amendment. See United States v. McMillon, 350 F. Supp 593 (D.D.C. 1972)(video of backyard not a search); People v. Wemette, 728 N.Y.S.2d 805, 805 (N.Y. App. Div. 2001) (videotaping defendant on his open front porch exposed to plain view of public did not infringe any reasonable expectation of privacy); State v. Holden, 964 P.2d 318, 320-22 (Utah Ct. App. 1998)(videotape of front yard from neighbor's window not a search). But see U.S. v. Cuevas-Sanchez, 821 F.2d 248 (5th Cir. 1986) (prolonged video surveillance of backyard is a search).

107 See, e.g., Costin, 720 A.2d at 870 ("this is not a case where video surveillance is aimed indiscriminately at public places and captures lawful activities of many citizens in the hope that it will deter crime or capture what crime might occur"); Augafa, 992 P.2d at 737 n.14 (after noting that the camera's zoom capaci- 
governs electronic eavesdropping, applies (with some modifications) to video surveillance of the home and similarly private locations, ${ }^{108}$ but none has held that it also applies to surveillance of public activities.

It is worth noting that no court has considered a Fourth Amendment challenge to a CCTV system, and that most of the decisions holding that the Fourth Amendment does not apply to shorter-term, spot surveillance have involved covert, rather than overt, camera use. ${ }^{109}$ But the bottom line is that legislatures have not enacted meaningful regulation of public video surveillance by the government, and the courts have been unwilling to nudge them in that direction. That should change.

\section{The Right to Public ANONYMity}

Suppose that the local police in a particular jurisdiction were to decide to station a police car at the entrance to the parking lot of a well-patronized bar from 5:30 p.m. to 7:30 p.m. every business day for the purpose of making a list of the license plates of cars that were driven in and parked in the lot during that time.... If we assume that the bar has the necessary liquor license to sell drinks, that nothing more is known about the individuals patronizing the bar than that they happen to drive into its parking lot at this hour, and that there are no other special circumstances present, I would guess that the great majority of people who might have the question posed to them would say that this is not a proper police function.... [T]here would be an uneasiness, and I think a justified uneasiness, if those who patronized the bar felt that their names were being taken down and filed for future reference. ... [T] [Tis ought not to be a governmental function when the facts are as extreme as I put them. ${ }^{110}$

ty probably did not play a major role in defendant's arrest, stating "there may be circumstances under which video camera surveillance, even in a public place, may constitute an unconstitutional intrusion violative of our state constitution's guarantee against unreasonable searches, seizures, and invasions of privacy.")

108 See, e.g., United States v. Torres, 751 F.2d 875 (7th Cir. 1984).

109 See cases cited supra note 106.

110 William H. Rehnquist, Is An Expanded Right of Privacy Consistent with Fair and Effective Law Enforcement? Or: Privacy, You've Come a Long Way, Baby, 
These words were written by William Rehnquist, soon after he was appointed to the United States Supreme Court in 1972. $\mathrm{He}$ is right that overt police monitoring of the comings and goings of individuals for no apparent reason is not an appropriate government function; as he says later in his article, the "interest in not having public activities observed and recorded may prevail in the absence of any governmental justification for the surveillance. ${ }^{\text {p11 }}$ The only thing wrong about the passage set out above is that the hypothesized facts are not "extreme." They describe a practice that would be quite feasible and even routine with any video surveillance system that openly records public activity.

Rehnquist also asserted that the individual interest involved in this situation, although deserving of protection, is not "privacy," because the observed action "is not intended to be concealed or confidential and is not in fact concealed or confidential."112 It is true that no particular trip to the bar is concealed. But it is also true that those who make trips to the bar think that their observers either will not know or care who they are, or will be acquaintances or other bar patrons readily distinguishable from impersonal government observers bent on collecting information. Those who patronize bars or any other establishment both expect, and normally can count on, concealment from the latter type of observation. If the "uneasy" reaction to which Rehnquist refers is not based on a sense of privacy invasion, it stems from something very close to it-a sense that one has what I will call "a right to public anonymity."

Anonymity, literally, means nameless. ${ }^{113}$ The right to public anonymity provides assurance that, when in public, one will remain nameless-unremarked, part of the undifferentiated crowd-as far as the government is concerned. The right is sur-

23 KAN. L. REV. 1, 9 (1974).

111 Id. at 14. Rehnquist also states, "I think almost all of us would regard this as simply not the kind of governmental interest that ought to rate high in a free society." Id. at 11.

112 Id. at 9.

11s Webster's New Collegiate Dictionary 47 (1977)(defining anonymous as "having or giving no name"). 
rendered only when one does or says something that merits government attention, which most of the time must be something suggestive of criminal activity. ${ }^{114}$

The association of public anonymity with privacy is not new. In his seminal study of privacy, Peter Westin years ago described anonymity as a "state of privacy" that "occurs when the individual is in public places or performing public acts but still seeks, and finds, freedom from identification and surveillance. ${ }^{115}$ Westin continued:

He may be riding a subway, attending a ball game, or walking the streets; he is among people and knows that he is being observed; but unless he is a well-known celebrity, he does not expect to be personally identified and held to the full rules of behavior and role that would operate if he were known to those observing him. In this state the individual is able to merge into the "situational landscape."

While most would probably agree with the intuitions of Rehnquist and Westin that we expect some degree of anonymity in public, the burden of this article is to establish a constitutional right to such anonymity. I will do so from three perspectives. First, I show how indiscriminate technological public surveillance seriously undermines the way we would like our society to function, because of its effect on public anonymity. Second, I argue that a number of constitutional principles, while not explicitly recognizing a right to public anonymity, provide solid groundwork for it. Finally, I report the results of an empirical study that suggests that American citizens feel public camera surveillance by the government is more intrusive than a variety of other police actions that the Supreme Court has labeled a "search" or "seizure," a finding that bolsters the case for folding the right to anonymity into the Fourth Amendment's protections.

114 The right might also give way to prevent harm to others that is not criminal (e.g., an impending accident), or when a person needs medical attention, etc.

115 Allan F. Westin, PRTACy aNd Freedom 31 (Bodley Mead 1967).

116 Id. 


\section{A. The Impact of Losing Public Anonymity}

Anonymity in public promotes freedom of action and an open society. Lack of public anonymity promotes conformity and an oppressive society. These sentences summarize the conclusions of a host of thinkers about public privacy.

\section{The Panopticon Analogy}

The antithesis of public anonymity is the Panopticon, a model prison first imagined by Jeremy Bentham. ${ }^{117}$ The Panopticon is circular, with the prison cells and walkways placed around the perimeter and the guard station perched on top of a tower in the middle, an arrangement which enables a large number of prisoners to be watched by just a few guards. ${ }^{118}$ In theory, every movement of every convict could be monitored in such a building.

But the genius of this construction is that the guards, who are hidden by venetian blinds, do not actually have to watch in order to enforce order. The mere knowledge that one could be observed converts every prisoner into his or her own warden. This latter observation is a key point of emphasis for Michel Foucault, the renowned philosopher and historian, who elaborated extensively on the modern implications of the Panopticon. ${ }^{119}$ As he recognized, "[h]e who is subjected to a field of visibility, and who knows it, assumes responsibility for the constraints of power; ... he becomes the principle of his own subjection." ${ }^{120}$

Of course, prisoners are subject to rigid rules of discipline, violation of which can result in serious punishment. "Self-subjection" might not work as well when those in charge of the

117 See IV THE WORKS OF JeREMY BenthaM 37-172 (John Bowring ed., 1962)(1838-43).

118 Id. at $60-64$.

11 See generally Michate Foucault, DiscIPLINE AND PUNISH 195-229 (Alan Sheridan, trans., Vintage Books $2 d$ ed. 1995)(1978)

${ }^{120}$ Id. at 202-03. See also, id. at 187 ("It is the fact of being constantly seen, of being able always to be seen, that maintains the disciplined individual in his subjection."). 
surveillance do not have reprisal power analogous to prison officials. Foucault asserted, however, that modern society increasingly functions like a super Panopticon, one which "assures the automatic functioning of power," by rendering "its actual exercise unnecessary." ${ }^{121}$ As both public and private entities pour more resources into methods of monitoring people and architecture that facilitates it, Foucault felt, ordinary citizens aware of this monitoring are likely to feel increasing pressure to conform to whatever norms the observers are perceived to endorse. $^{122}$

For Foucault, this "panopticism" is not necessarily a bad thing. He described it as "a functional mechanism that ... improve[s] the exercise of power by making it lighter, more rapid, more effective," than the older, balder ways of ensuring appropriate conduct. ${ }^{123}$ Through the "subtle coercion" of panopticism, people can be led to be more productive, efficient members of society. ${ }^{124}$ In the workplace, hospital or school, the types of situations Foucault had in mind, one can see some logic in this conclusion. In those locations, specific rules govern people's actions, rules that might be enforced most efficiently through surveillance.

To the extent such "subtle coercion" operates on those in the public byways, however, it can only do damage to cherished values. To see why, consider first Justice Douglas' comments in Papachristou v. Jacksonville ${ }^{125}$ about public vitality in America:

Walk[ing] and stroll[ing] and wander[ing] . . are historically

121 Id. at 201.

122 See id. at 170-176 (discussing how "the exercise of discipline presupposes a mechanism that coerces by means of observation" in military camps, hospitals, schools and workshops and factories); $i d$. at 205 ("The Panopticon . . . must be understood as a generalizable model of functioning; a way of defining power relations in terms of the everyday life of men.").

${ }^{125}$ Id. at 209; see also id. at 202 (in a panoptic regime "it is not necessary to use force to constrain the convict to good behaviour, the madman to calm, the worker to work, the schoolboy to application, the patient to the observation of the regulations.").

124 Id.

125405 U.S. 156, 164 (1972). 
part of the amenities of life as we have known them.... These unwritten amenities have been in part responsible for giving our people the feeling of independence and self-confidence, the feeling of creativity. These amenities have dignified the right of dissent and have honored the right to be nonconformists and the right to defy submissiveness. They have encouraged lives of high spirits rather than hushed, suffocating silence. ${ }^{126}$

Quoting Walt Whitman and Henry David Thoreau, among others, Douglas painted a picture of a society that thrives on free-spiritedness in public. ${ }^{127}$

Now consider, in contrast, some of the effects that Foucault ascribes to the "discipline" that he says comes from panopticism. He tellingly calls this discipline "an anti-nomadic technique." ${ }^{\prime 28}$ Because it inhibits behavior, it "arrests or regulates movements [and] dissipates compact groupings of individuals wandering about the country in unpredictable ways. ... "129 It also can "neutralize the effects of counterpower that spring from [the multiple organizations in society] and which form a resistance to the power that wishes to dominate it: agitations, revolts, spontaneous organizations, coalitions-anything that may establish horizontal conjunctions." 130 These effects are inconsistent, to put it mildly, with Douglas' vision of the conditions that a democratic, open society wants to nurture in its public spaces.

\section{The Effects of Being Watched}

How, more specifically, does panopticism undermine public openness? Foucault does not answer this question in detail. Others have, in ways that are directly relevant to public camera surveillance. Shoshana Zuboff writes about the phenome-

126 Papachristou, 405 U.S. at 164.

127 Id. at 164 (noting Whitman's "Song of the Open Road," Vachel Lindsay's "I Want to Go Wandering," and an excerpt from Henry David Thoreau about the "successful saunterer").

${ }^{128}$ Foucault, supra note 119 , at 218.

120 Id. at 219.

150 Id. 
non of "anticipatory conformity" among persons who believe they are being watched. ${ }^{131}$ Similarly, philosopher Jeffrey Reiman states that "[w]hen you know you are being observed, you naturally identify with the outside observer's viewpoint, and add that alongside your own viewpoint on your action. This double vision makes your act different, whether the act is making love or taking a drive. ${ }^{\prime 132}$ These observations suggest that any number of individuals-ranging from political demonstrators, ${ }^{133}$ to couples-in-love and carefree teenag$\mathrm{ers}^{134}$-could be inhibited by the knowledge their actions may be captured on camera.

"Double vision" is even more likely when the surveillance involves not just observation but recording of one's activities. For then, Professor Richard Wasserstrom notes, "[n]o matter how innocent one's intentions and actions at any given moment ... persons would think more carefully before they did things that would become part of the record. Life would to this degree become less spontaneous and more measured." ${ }^{\text {135 }}$ As

131 Shoshana Zuboff, In the Age of the Smart Machine: The Future of WORK AND POWER 344- 45 (1988).

192 Jeffrey H. Reiman, Driving to the Panopticon: A Philosophical Exploration of the Risks to Privacy Posed by the Highway Technology of the Future, 11 SANTA Clara Computer \& High TECH. L. J. 27, 38 (1995). Reiman goes on to say: "To the extent that a person experiences himself as subject to public observation, he naturally experiences himself as subject to public review. As a consequence, he will tend to act in ways that are publicly acceptable." Id. at 41.

193 As Roger Clarke states, "[l]eaders of demonstrations in the future should expect . . . their locations to be transparent to the police." Roger Clarke, While You Were Sleeping ... Surveillance Technologies Arrived, 73 AUSTRALIAN QUARTERLY 1 (2001), available at http://www.anu.edu.au/people/Roger.Clarke/DV/ AQ2001.html.

134 These latter kinds of activities are apparently routinely spied upon by camera operators. See DeGregory, supra note 28 , at $1 \mathrm{D}$ (quoting camera operator as saying, "I've seen it all. Some things are really funny, like the way people dance when they think no one's looking. Others, you wouldn't want to watch."); NoRRIS \& ARMSTRONG, supra note 44, at 129 ("10 percent of all targeted surveillances on women, and 15 percent of operator-initiated surveillance were for apparently voyeuristic reasons, outnumbering protective surveillance by five to one."); see also, id. at 130 ("The 'appreciation' of such public displays [of sex in cars] was a regular feature of the night shift in one of our suites and not just confined to those with access to the monitors. Many such encounters could be found on the 'shaggers alley greatest hits tape' which was compiled and replayed for the benefit of those who missed the 'entertainment." ).

${ }^{135}$ Richard Wasserstrom, Privacy: Some Arguments and Assumptions, in 
Professor Daniel Solove has noted, the behavioral impact of surveillance is heightened by the reasonable surmise that one's recorded actions are easily susceptible to aggregation and use by a faceless bureaucracy. ${ }^{136}$ Professor Nicolas Burbules similarly notes that "[a]s people accept the inevitability of being observed and recorded, their habits change; they change." He goes on to assert that these changes are even more pervasive than we might think, because "people carry many of the attitudes and self-imposed restrictions of activity from the surveyed public into their private life." ${ }^{\text {137 }}$

The stultifying effect of public surveillance has been noted by many others. ${ }^{138}$ But spontaneity is not all that could be hindered by routine public surveillance. Richard McAdams notes, "[t]he problem drinker who goes to an Alcoholics Anonymous meeting, the patient who drives to his psychiatrist's office, the homosexual who visits a gay bar, the spouse who has a

Phimosophical Dimgnsions of Privacy 325-26 (Ferdinand David Schoeman, ed., Cambridge Univ. Press 1984); cf. United States v. White, 401 U.S. 745, 788 (1971)(Harlan, J., dissenting)("Authority is hardly required to support the proposition that words would be measured a good deal more carefully and communication inhibited if one suspected his conversations were being transmitted and transcribed. Were third-party bugging a prevalent practice, it might well smother that spontaneity-reflected in frivolous, impetuous, sacrilegious, and defiant discourse-that liberates daily life.").

${ }_{136}$ See Daniel J. Solove, Conceptualizing Privacy, 90 CAL. L. REv. 1087, 1154 (2002) ("What makes this problem [of information collection through surveillance] significant is the fact that this information is aggregated, that it can be used to make important decisions about people's lives, that it is often subjected to a bureaucratic process lacking much discipline and control, and that the individual has scant knowledge of how the information is processed and used.").

${ }^{137}$ Nicholas C. Burbules, Privacy, Surveillance, and Classroom Communication on the Internet, available at http:/faculty.ed.uiuc.edu/burbules/ncb/papers/privacy. html (last visited Oct. 25, 2002).

${ }^{238}$ See, e.g., ANita Allen, Uneasy Access: Privacy for Women in a Free SOCIETY 124 (1988)(stating that public "anonymity is wrongfully disturbed if uninvited attention is paid or drawn to another person without justification," because that disturbance "impedes individual tasks and purposes"); Stanley I. Benn, Privacy, Freedom, and Respect for Persons, in Nomos XIII: PRIVACY 26 (J. Ronald Pennock \& J.W. Chapman eds., 1971) (The observed "becomes aware of himself as an object, knowable, having a determinate character [and] is fixed as something-with limited probabilities rather than infinite, indeterminate possibilities."); cf., LAWRENCE LesSIG, CODE AND OTHER LAWS OF CYBERSPACE 152-53 (1999) ("Privacy, or the ability to control data about yourself ... disables the power of one dominant community to norm others into oblivion"). 
rendezvous with another lover, the teenager or adult who skips school or work to go fishing, would all be exposed if someone constantly tracked their public movements." ${ }^{\text {139 }}$ The practice of seeking secret solace in parks and other public places may also be circumscribed. ${ }^{140}$ None of these activities are illegal, but it is easy to imagine why those who engage in them might want to keep them secret.

In addition to its effect on behavior, CCTV might trigger a number of unsettling emotional consequences. Relying on the work of Erving Goffman, Jeffrey Rosen notes that “it's considered rude to stare at strangers whom you encounter in public."141 Staring, whether it occurs on an elevator, on public transportation or on the street, violates the rules of "civil inattention." ${ }^{142}$ The cyclopian gaze of the camera eye may be equally disquieting, and perhaps more so given the anonymity of the viewer and the unavailability of normal countermeasures, such as staring back or requesting the starer to stop.

The small amount of social science research specifically aimed at assessing the impact of concerted surveillance tends to verify that these and other psychological and behavioral effects can occur. For instance, empirical investigations of the workplace-one of the contexts Foucault thought might benefit from panopticism-indicate that even there surveillance has a downside. Monitored employees are likely to feel less trusted, less motivated, less loyal, and more stressed than employees who are not subject to surveillance. ${ }^{143}$ Whether these findings

139 Richard H. McAdams, Tying Privacy In Knotts: Beeper Monitoring and Collective Fourth Amendment Rights, 71 VA. L. REv. 297, 322 (1985).

${ }^{140}$ Disa Sim, The Right to Solitude in the United States and Singapore: A Call for a Fundamental Reordering, 22 LoyolA L.A. ENT. L. REv. 443, 468 (2002)(noting that "[i]n a crowded society, we are often driven to find peace and solace in public parks, pubs, and other public places," and asserting that this practice would be inhibited by wide-open public photography).

141 Jefrrey Rosen, The UNWanted Gaze: The Violation of OUR PRIVACY 16 (2000)(citing Erving Goffman, Behavior IN PUblic Places: Notes ON THE SOClal Organization of Gatherings 84-85, 116 (1963)).

162 Id.

14 The best research in this regard comes from Carl Botan. In one study, based on the responses of 465 workers in the communications industry, he found that "[e]mployees who are surveilled ... experience several panoptic effects, including a reduced sense of privacy, increased uncertainty [as to job security], and 
would be duplicated in the public surveillance context is not clear. ${ }^{144}$ But one could plausibly infer from them that citizens on the street who are subject to camera surveillance might experience less confidence in their overall freedom to act, as well as somewhat diminished loyalty to a government that must watch its citizens' every public movement. Roger Clarke also calls attention to the latter possibility in his study of the effects of widespread surveillance. Among the many consequences of "dataveillance," as he calls it, are a prevailing climate of suspicion, an increase in adversarial relationships between citizens and government, and an increased tendency to opt out of the official level of society. ${ }^{145}$

reduced communication." Carl Botan, Communication Work and Electronic Surveillance: A Model for Predicting Panoptic Effects, 63 CoMM. MoNogRaPHS 293, 30809 (1996). The main conclusions of a second study based on the same survey results, conducted with Professor Vorvoreanu, were as follows:

[T]he overwhelming meta-message that surveillance seems to send to employees is that they are distrusted. . . . In a closely related interpretation, many employees see surveillance as setting someone, possibly themselves, up for dismissal or discipline. . . . Many subjects also perceive surveillance as implying that management feels they deserve to be treated as children, .... and heavily surveilled employees reported reduced motivation to do more quantity of work . . . and reduced motivation to do higher quality work .... Finally, heavily surveilled subjects reported reduced loyalty to the organization, increased stress at work, and reduced enthusiasm about even going to work, all of which are supported by qualitative comments ....

Carl Botan \& Mihaela Vorvoreanu, "What Are You Really Saying to Me?" Electronic Surveillance in the Workplace (June 2000)(unpublished manuscript, on file with author).

14 Surveys asking what people think of CCTV routinely produce overwhelmingly positive results. See infra note 264-65 and accompanying text. But no survey, outside of the one reported here, see infra text accompanying notes $272-84$, has focused on CCTV's panoptic effects (and even the study reported here does so only indirectly). Further, the way survey questions about CCTV have been framed apparently distorts the results obtained. See Jason Ditton, Public Support for Town Centre CCTV Schemes: Myth or Reality?, in SuRvenlance, Closed CiRCuIT TELEVISION AND SOCIAL CONTROL, supra note 73, at 227 (finding that positive question-framing increased CCTV's acceptance by $20 \%$, and that if that proportion were subtracted from the $69 \%$ positive response in previous professional surveys, "we have a minority-albeit a very large minority-but only a minority finding open street city centre CCTV acceptable.").

14 Roger Clarke, Information Technology and Dataveillance, 31 CoMM. ACM 498 (May 1988) available at http:// www.anu.edu.au/people/Roger.Clarke/DV/

CACM88.html). 
To capture the core of these disparate observations, consider again Rehnquist's bar example. The people entering the bar will feel less trusted, and more anxious, and may even stop going there. Or try another simple thought experiment. Virtually all of us, no matter how innocent, feel somewhat unnerved when a police car pulls up behind us. Imagine now being watched by an officer, at a discreet distance and without any other intrusion, every time you walk through certain streets. Say you want to run (to catch a bus, for a brief bit of exercise or just for the hell of it). Will you? Or assume you want to obscure your face (because of the wind or a desire to avoid being seen by an officious acquaintance)? How about hanging out on the street corner (waiting for friends or because you have nothing else to do)?

In all of these scenarios, you will probably feel and perhaps act differently than when the officer is not there. Perhaps your hesitancy comes from uncertainty as to the officer's likely reaction or simply from a desire to appear completely law-abiding; the important point is that it exists. Government-run cameras are a less tangible presence than the ubiquitous cop, but better at recording your actions. A police officer in Liverpool, England may have said it best: A camera is like having a cop "on duty 24 hours a day, constantly taking notes. ${ }^{\text {146 }}$

\section{The Government's Use of Surveillance}

All of these inhibitory consequences can be produced simply by setting up a camera system. If the government acts on what the camera sees, those effects can be significantly enhanced. Of course, that is all to the good if the result is prevention of serious criminal behavior. But sometimes government uses surveillance to achieve more ambiguous ends. Many of the crimes "solved" through CCTV in England are very minor offenses that are highly subject to discriminatory prosecution, such as littering, urinating in public, traffic violations, drunkenness, loitering, failing to pay parking meters and even underage smoking. ${ }^{147}$ Indeed, camera use in publicly accessible

146 Quoted in News, CCTV Today, May, 1995, at 4.

147 Simon Davies, Welcome Home Big Brother, WIRED, May, 1995, at 58-62, 
malls in that country triggers law enforcement interventions even when there is no infraction of the criminal law; rather, the decision is often based on "commercial considerations" that characterize certain people (beggars, buskers, and groups of youth) as "flawed consumers."148 Research suggests that, in other public areas as well, the impact of surveillance tends to be the straightforward exclusion of disfavored groups rather than apprehension or deterrence of criminals. ${ }^{149}$

Thus, Professor Jeffrey Rosen concludes, CCTV's primary use in Great Britain today is not to thwart serious crime but "to enforce social conformity." ${ }^{" 150}$ One consequence, he reports, is that the cameras are "far less popular among black men than among British men as a whole."151 That should be no surprise to those familiar with the American experience with loitering laws, stop and frisk practices, and "aggressive patrolling. ${ }^{\text {"152 }}$ Others view CCTV as one of the most powerful forces

cited in Graham, supra note 77, at 101.

140 Michael McCahill, The Surveillance Web: The Rise and Extent of Visual Surveillance in a Northern City (unpublished Ph.D. thesis, Hull University), cited in Norris, supra note 40, at 28 (using this term); see also Alice Wakefield, Situational Crime Prevention in Mass Private Property, in ETHICAL AND Social PERSPECTIVES ON Situational CRIME PReVEntion 125, 133 (Andrew von Hirsch et al. eds., 2000)(reporting 578 persons excluded from shopping and arts centers during a five-week period as a result of CCTV-based security system).

${ }^{149}$ See Alan Reeve, The Panopticisation of Shopping: CCTV and Leisure Consumption, in Survenlance, Closed Circuit Television and Local Control, supra note $\mathbf{7 3}$, at 78 (reporting that town center managers wanted to use CCTV primarily to discourage "anti-consumer" people and activities from entering the center, and that a quarter wanted to exclude political gatherings, youth who want to "hang out" and beggars); Roy Coleman \& Joe Sim, "You'll Never Walk Alone": CCTV Surveillance, Order and Neo-Liberal Rule in Liverpool City Centre, 51 BRT. J. Soc. $623(2000)$ (reporting a study leading the authors to conclude that "[t]he activities targeted, the gathering of intelligence and its dissemination is focused on recurring categories: youth, 'known and potential' shoplifters, the homeless and licensed and unlicensed street traders."); Liberty: Who's Watching You? Video Surveillance in Public Places 1 (London Briefing Paper No. 16, 1989)(on file with author)(asserting that cameras are designed to deter "lange groups, usually young single people [whose] mere presence is a nuisance to people who want to use the streets and shopping centres in more conventional ways.").

150 Jeffrey Rosen, A Watchful State, N.Y. Trmes MAG., Oct. 7, 2001, at 38.

151 Id. See also, Taylor, supra note 48, at I 31 (reporting that soon after installation of cameras in Newcastle local residents attacked the community center, in the belief it housed the camera monitoring room).

${ }^{152}$ See generally Dorothy E. Roberts, Foreword: Race, Vagueness, and the So- 
pushing toward the "purification" of city spaces and their destruction as a stage for the "celebration of difference" and disorder. ${ }^{153}$ The end result of all of this is that public spaces are becoming less public. ${ }^{154}$

Automated systems that do not depend on human operators have been hailed as a method of avoiding these biases. ${ }^{155}$ But they do not necessarily eliminate racist and other undesirable tendencies, since discretion is still exercised once the alarm is triggered. Facial recognition systems that are based simply on whether a person has previously been labeled a "shoplifter" or "car thief" (sometimes erroneously ${ }^{156}$ ) are likely to exacerbate these tendencies. If one tries to remove the impact of human flaws through full automation (as with the motion detection systems described earlier), the result is even more alarming. Such systems are based on rigid categorizations of behavior. As Norris notes, "they utilize no other logic than

cial Meaning of Order-Maintenance Policy, 89 J. CRM. L. \& CRIMNOLOGY 775 (1999)(exploring how order maintenance policies reinforce and are reinforced by preconceived notions of African-American criminality).

15s Jon Bannister et al., Closed Circuit Television and the City, in SuRvellLANCE, Closed CIRCUIT Television aNd LoCal CONTROL, supra note 73, at 24-32. These authors conclude that CCTV "as an urban management tool . . . is part of the wider urban malaise."

By employing such techniques, by closing ourselves to difference, we run the unintended and perverse risk of further weakening our capacity to manage difference. Difference becomes even more threatening. Public sociability is weakened. Spaces become the responsibility of urban managers, order becomes a good to be accessed through consumption.

Id. at 36 .

154 Taylor, supra note 48, at I 23 ("Shopping malls and city centres are becoming increasingly purified and privatised to the extent that the limits of acceptable behaviour are being driven by the forces of consumerism. Public spaces are becoming increasingly less public.")

156 Michalis Lianos \& Mary Douglas, Dangerization and the End of Deviance: The Institutional Environment, 40 BRIT. J. CrImInoLOGY. 261, 266 (2000)("It is the first time in history that we have the opportunity to experience forms of control that do not take into account any category of social division. ... [A]utomated environments . . . cannot discriminate among users on other grounds than their quality as users.").

${ }^{106}$ Amy Herdy, They Made Me Feel Like a Criminal, St. Petersburg Tmmes, Aug. 8, 2001, at 1B (recounting story of police confronting a man erroneously identified by Tampa's facial recognition system as someone wanted for child abuse). 
whatever is programmed into their software, and the end point of such processing is the creation of a binary system of classification: access is either accepted or denied; identity is either confirmed or rejected; behavior is either legitimate or illegitimate."157

The implications of these various considerations should not be overstated. Contrary to the dire predictions of some privacy advocates, the potential effects of public surveillance are not Orwellian in magnitude. A principal feature of the society depicted in George Orwell's novel 1984 was the ever-present "telescreen" that relayed citizens' words and conduct back to an omniscient "ministry." ${ }^{\text {"158 }}$ But the dread that was rampant in Orwell's fictional Oceania resulted primarily from the perception that the government was obsessed with severely punishing amorphously defined "thoughtcrimes" and "facecrimes," often with death. ${ }^{159}$ In the real world today, in contrast, the norms likely to assume importance because of camera surveillance (aside from standard criminal prohibitions), come from the

157 Norris, supra note 40 , at $40-41$.

1se See, e.g., Orwell, supra note 3, at 6-7 (the telescreen "could be dimmed, but there was no way of shutting it off completely. . . . [It] received and transmitted simultaneously. ... . You had to live-did live, from habit that became instinct-in the assumption that every sound you made was overheard, and, except in darkness, every movement scrutinized."). Harry Strub, The Theory of Panoptical Control: Bentham's Panopticon and Orwell's Nineteen Eighty-Four, 25 J. HIST. BEH. ScI. 40, 44 (1989)(“The telescreen . . . provided a nearly continuous, permanent record of virtually all of an individual's actions, however trivial, and thereby represents the consummation of the panoptical ideal of being able to observe everything.").

${ }^{159}$ See, e.g., Orwell, supra note 3, at 19-20:

Whether he wrote DOWN WITH BIG BROTHER, or whether he refrained from writing it, made no difference... The Thought Police would get him just the same. . . Thoughtcrime, they called it. Thought-crime was not a thing that could be concealed forever. . . In the vast majority of cases there was no trial, no report of the arrest. People simply disappeared, always during the night. . . . You were abolished, annihilated: vaporized was the usual word.

See also, Strub, supra note 158, at 44 ("In [the telescreen's] all-seeing function, it was vastly more sensitive, surpassing the Panopticon's potential of achieving power over minds: one was aware that even the presence of a forbidden thought ("thoughtcrime") was detectable, betraying the individual by a small gesture or grimace ("facecrime"), or by more minute emotional signals of guilt such as respiratory and heartbeat changes."). 
conscience of the mainstream and the business class, the imagination of pedestrians and the calculations of technicians, and they are more likely to result in exclusion from certain areas than any significant formal punishment.

At the same time, in a society that wants to promote freedom of action, camera surveillance-more specifically, concerted, overt public surveillance using cameras with recording capacity-is clearly not an unalloyed good, even if it does significantly reduce crime. People who know they are under government surveillance will act less spontaneously, more deliberately, less individualistically, and more conventionally; conduct on the streets that is outside the mainstream, susceptible to suspicious interpretation, or merely conspicuous-even if perfectly harmless-will diminish and perhaps even be officially squelched. Some people subject to public camera surveillance, perhaps in particular those from minority groups, will feel significant anxiety and discomfort although innocent of any crime, and some may react with disdain for government, again despite and probably because of their innocence. ${ }^{160}$ Public camera surveillance undermines an open society because it circumscribes unordinary behavior and makes everyone-including the ordinary-more conscious of the government's presence, at least until behavior is suitably conformed and the cameras can be forgotten. ${ }^{161}$ In short, CCTV accelerates the “disappearance of disappearance." ${ }^{\text {162 }}$

${ }^{100}$ In an ideal world, perhaps, people would not succumb to these underenforced norms, implemented solely through the process of being watched and recorded. But, Professor Reiman notes, "[e]ven if people should ideally be able to withstand social pressure in the form of stigmatization or ostracism, it remains unjust that they should suffer these painful fates simply for acting in unpopular or unconventional ways." Reiman, supra note 132, at 36 .

181 Foucault's writings predict this result. The cameras will affect our behavior and attitudes, and then both their effect and their existence will fade from our consciousness. We would be changed without realizing how or why. See Burbules, supra note 137 (noting that, consistent with Foucault's thesis, "few people even notice any longer how frequently they are monitored through partially hidden video cameras," despite the fact that this surveillance inhibits "all sorts of activities-and not only illegal activities").

10 Kevin D. Haggerty \& Richard V. Ericson, The Surveillant Assemblage, 51 BRTT J. Soc. 605, 619 (2000)( “The coalescence of [data collection] practices into the surveillant assemblage marks the progressive 'disappearance of 


\section{B. The Constitution and Public Camera Surveillance}

Do the potential effects of public camera surveillance on public anonymity raise constitutional concerns, or are they merely subconstitutional matters that policymakers can take into account, or dismiss, at their discretion? Camera surveillance is certainly not as physically intrusive as an arrest or stop, or as invasive as a search of houses or belongings, the paradigmatic government actions addressed by the Fourth Amendment. But its aggregate impact can be equally significant, because it affects a much larger number of people. It also evokes a particularly powerful image, a panoptic approach to government interaction with its citizens that involves observing, recording, and categorizing every movement in public.

As Lawrence Tribe has emphasized, the Constitution should be interpreted with the "constitutive dimension of government action" in mind. ${ }^{163}$ We should think about the issues raised by public camera surveillance "in terms of what they say about who and what we are as a people and how they help to constitute us as a nation. ${ }^{164}$ As it turns out, not just the Fourth Amendment but a number of other provisions in the Constitution are relevant to that endeavor.

\section{Freedom of Speech and Association}

The First Amendment guarantees freedom of speech and association. ${ }^{165}$ Recall Justice Douglas' words in Papachristou linking wandering and strolling with the right to dissent, nonconformity, and defiance of submissiveness. ${ }^{166}$ Building on that language, one might argue for a First Amendment right to be free of the inhibiting effects of camera surveillance in public

disappearance'-a process whereby it is increasingly difficult for individuals to maintain their anonymity, or to escape the monitoring of social institutions.").

10* Lawrence Tribe, Seven Deadly Sins of Straining the Constitution Through a Pseudo-Scientific Sieve, 36 HASTINGS L.J. 155, 165 (1984).

104 Id.

${ }_{165}$ U.S CONST. amend. I (“Congress shall make no law ... abridging the freedom of speech, or of the press; or the right of the people peaceably to assemble ...." ${ }^{4}$ ).

${ }^{168}$ See supra text accompanying notes $125-27$. 
unless the government can proffer some justification for it.

Under the Supreme Court's caselaw, however, neither the speech or association guaranties are likely to provide a basis for constitutional regulation of most public surveillance, at least when it is visual only. ${ }^{167}$ While conduct alone can be expressive, the type of conduct normally captured by cameras apparently does not fit in this category. As the Court stated in City of Dallas $v$. Stanglin, "[i]t is possible to find some kernel of expression in almost every activity a person undertakes-for example, walking down the street, or meeting one's friends at a shopping mall-but such a kernel is not sufficient to bring the activity within the protection of the First Amendment." 168 Similarly, government inhibition of association is generally not a violation of the First Amendment unless the group is engaged in some type of speech activity. ${ }^{169}$

However, if public conduct is expressive-for instance, a speech at a park rally-and public associations are speech-related-such as joining the rally-then the First Amendment should be implicated by camera surveillance. That is because, as the previous section suggested, such surveillance can chill conduct, even though it takes place in public and is meant to be seen by others.

Admittedly, the Supreme Court rejected a similar claim in Laird $v$. Tatum. ${ }^{170}$ There the plaintiffs contended that their antiwar activities were inhibited by knowledge that the Army

107 If cameras are equipped with parabolic audio capacity, so that they can pick up "private" conversations on the street, their use would probably require a warrant under both the Fourth Amendment, see infra note 280 and accompanying text, and Title III, see 18 U.S.C. $\& 2510(2)(2002)$ (protecting oral communications "by a person exhibiting an expectation that such communication is not subject to interception under circumstances justifying such expectation"). If audio recording capacity were used openly, Title III might not be violated, but the types of arguments made below concerning the "chilling" effect of surveillance would be apposite.

168 City of Dallas v. Stanglin, 490 U.S. 19, 25 (1989).

160 Stanglin, 490 U.S. at 25 ("we do not think the Constitution recognizes a generalized right of 'social association' that includes chance encounters in dance halls. . . . Griswold [v. Connecticut, 381 U.S. 479 (1965)] . . recognizes nothing more than that the right of expressive association extends to groups organized to engage in speech that does not pertain directly to politics.").

170408 U. S. 1 (1972). 
was constructing dossiers on those involved, allegedly as a means of averting potential civil disorder. Construing the question to be "whether the jurisdiction of a federal court may be invoked by a complainant who alleges that the exercise of his First Amendment rights is being chilled by the mere existence, without more, of a governmental investigative and datagathering activity that is alleged to be broader in scope than is reasonably necessary for the accomplishment of a valid governmental purpose, ${ }^{171}$ the Court dismissed the case. According to the five-member majority, the plaintiffs had no standing because they failed to allege any specific, foreseeable harm, other than an inchoate fear that the information would somehow be used against them. ${ }^{172}$

The Court has since indicated, however, that a government action the sole effect of which is to chill speech is justiciable under some circumstances. ${ }^{173}$ Tatum thus does not necessarily foreclose a First Amendment argument against camera surveillance. The latter method of data collection is quite different from the government's efforts in Tatum. Most of the "surveillance" in Tatum consisted of perusing published material and public records, and the rest involved undercover agents who attended meetings; ${ }^{174}$ furthermore, the plaintiffs in Tatum alleged no specific acts by the Army against them, ${ }^{175}$ and may not have been "chilled" in any event. ${ }^{176}$ In short, Tatum did

17 Tatum, 408 U.S. at 10.

172 Id. at 13-14 ('Allegations of a subjective 'chill' are not an adequate substitute for a claim of specific present objective harm or a threat of specific future harm").

${ }^{173}$ Meese v. Keene, 481 U.S. 465, 478 (1987)(finding standing to argue that government labeling of a film as propaganda chilled the showing of the films, but ultimately finding no First Amendment violation because the labeling "neither prohibits nor censors the dissemination of advocacy materials").

${ }^{174}$ Tatum, 408 U.S. at 6.

175 Id. at 9 (Respondents "freely admit that they complain of no specific action of the Army against them. . . . So far as is yet shown, the information gathered is nothing more than a good newspaper reporter would be able to gather by attendance at public meetings and the clipping of articles from publications available on any newsstand.")

${ }^{176}$ Id. at 13-14 $\mathrm{n} .7$ ("[R]espondents . . have also cast considerable doubt on whether they themselves are in fact suffering from any ... chill. . . . [I]f respondents themselves are not chilled,... respondents clearly lack that personal stake in the outcome of the controversy' essential to standing."). 
not involve overt surveillance. The conspicuous presence of cameras aimed at participants engaging in First Amendment activity, in contrast, is closer to the type of "present] . . . compulsion $]^{m 177}$ directed at speech that has concerned the Court in cases where it has found violations of the First Amendment. ${ }^{178}$ Although many lower courts have nonetheless been hostile to First Amendment claims directed at camera surveillance (at least when it consists solely of photography), ${ }^{179}$ several have upheld standing claims when such surveillance targets individuals, intimidates them, or causes a falloff in attendance or membership, ${ }^{180}$ or when the results of the

17 Id. at 11.

178 For instance, in Lamont v. Postmaster General, 381 U.S. 301 (1965), the Court struck down a government regulation requiring individuals to make a special written request to the Post Office for delivery of mail containing communist literature. According to a unanimous Court, under such a regulation,

any addressee is likely to feel some inhibition in sending for literature which federal officials have condemned as "communist political propaganda." The regime of this Act is at war with the "uninhibited, robust, and wide-open" debate and discussion that are contemplated by the First Amendment.

Lamont, 381 U.S. at 307; see also Bantam Books, Inc. v. Sullivan, 372 U.S. 58 (1963)(finding the First Amendment violated when the city government sent letters that identified certain books as "objectionable," stated it would turn its list of distributors of those books over to police, and sometimes sent police officers to see whether distributors took any action with respect to the books). In both Lamont and Bantam Books the First Amendment wrong was the government's suggestion that the speech activity was inappropriate. In the absence of any other justification (such as public safety), the presence of government-run cameras at a political event strongly suggests that the government dislikes the message being transmitted, and will likely inhibit those involved in the observed activity. See supra notes 125-29 \& 133 and infra note 180.

${ }_{179}$ See, e.g. Donohoe v. Duling, 465 F.2d 196 (4th Cir. 1972) (finding no justifiable controversy where police conducted surveillance of demonstrations and public vigils and photographed demonstrators); Phila. Yearly Meeting of the Religious Society of Friends v. Tate, 519 F.2d 1335, 1337-38 (3d Cir. 1975)(no justiciable controversy where police photographed public meetings and disseminated information to other law enforcement agencies).

180 See Presbyterian Church (U.S.A.) v. United States, 870 F.2d 518 (9th Cir. 1989) (distinguishing Tatum because church suffered diminished membership as a result of surveillance); Olagues v. Russoniello, 797 F.2d 1511 (9th Cir. 1986)(distinguishing Tatum because plaintiffs here were targets of surveillance); cf., U.S. v. Montemarano, 1987 WL 13729 (S.D.N.Y. 1987), where the court stated:

It should be noted that the intrusion upon the spiritual and psychological 
surveillance are released to non-law enforcement entities. ${ }^{181}$

The chilling phenomenon has also long been recognized in other settings, particularly in labor cases involving suits under the National Labor Relations Act (NLRA) against employers who have photographed or videotaped employees engaging in authorized strikes and demonstrations. In $F . W$. Woolworth Co., ${ }^{182}$ a representative example, the National Labor Relations Board concluded that "absent proper justification, the photographing of employees engaged in protected concerted activities violates [rules under the NLRA against employer actions that have a "tendency to coerce"] because it has a tendency to intimidate." ${ }^{183}$ More so than mere observation, "pictorial recordkeeping tends to create fear among employees of future reprisals."184

As this last statement indicates, these holdings are bound up with the notion that employers have power over the employees. But that fact does not distinguish the labor cases from the public surveillance context. By definition, employer reprisals against those who engage in "protected concerted activities" are prohibited; yet the law recognizes that, regardless of "actual impact," photography can have an intimidating effect on employees so engaged. The same is true of speech and association in public. These are protected activities that should not result in government reprisal. But, understandably, people might not believe that is so when they know or think government cameras will be trained on them if they participate: If the activities are protected, why does the government need cameras? ${ }^{185}$

milieu preceding or following the services was minimized by the lack of a discernible law enforcement presence, the photographs having been taken from a concealed location. This is not a situation where uniformed government personnel impliedly, or expressly, menaced churchgoers.

Id. at *1.

181 Tate, supra note 179 , at 1338.

182310 N.L.R.B. 1197 (1993).

183 Woolworth, 310 N.L.R.B. at 1197.

184 Id. See also, Nat'] Steel v. N.L.R.B., 156 F.3d 1268 (D.C. Cir. 1998); Road Sprinkler Fitters Local Union No. 669 v. N.L.R.B., 681 F.2d 11, 19 (D.C. Cir. 1982)(citing cases); Waco, Inc., 273 N.L.R.B. 746, 747 (1984).

${ }^{185}$ David Feldman, Secrecy, Dignity or Autonomy? Views of Privacy as Civil Liberty, 41 C.L.P. 41, 61 (1994)(overt surveillance "carries with it a clearly im- 
A second way in which public camera surveillance trenches on First Amendment rights of speech and association is its facilitation of the government's ability to pierce the anonymity of those engaging in expressive conduct. The Court has declared that, absent a significant government justification, a person who writes a pamphlet ${ }^{186}$ or is involved in collecting signatures for a petition ${ }^{187}$ cannot be required to reveal his or her name. It has also held that membership lists of organizations need not be revealed. ${ }^{188}$ As Justice Stevens stated in McIntyre $v$. Ohio Elections Commission, ${ }^{189}$ whether " $[\mathrm{t}]$ he decision in favor of anonymity [is] motivated by fear of economic or official retaliation, by concern about social ostracism, or merely by a desire to preserve as much of one's privacy as possible ... [it] is an aspect of freedom of speech protected by the First Amendment." 190

People who engage in expressive conduct in public know they will be observed. But they may choose, like the pamphleteer or the petitioner, not to reveal their identity, for all sorts of reasons. Camera surveillance virtually nullifies that effort. Because the camera's recorded images are far better than an informer's memory, it vastly improves government efforts to link visages with names. Furthermore, as one commentator points out, "surveillance of a person's movements could, over

plied threat that the fruits of the surveillance may be used for purposes adverse to the interests of the person being watched. This is calculated to undermine people's commitment to their own plans and values.").

${ }^{186}$ Talley v. California, 362 U.S. 60, 64 (1960)(striking down a ban on anonymous handbills, noting that "[p]ersecuted groups and sects from time to time throughout history have been able to criticize oppressive practices and laws either anonymously or not at all.")

${ }^{187}$ Buckley v. Am. Constitutional Law Found., 525 U.S. 182, 200 (1999) (holding that Colorado's requirement requiring petition solicitors to wear an identification badge "discourages participation in the petition circulation process by forcing name identification without sufficient cause.").

188 NAACP v. Alabama ex. Rel Patterson, 357 U.S. 449, 462 (1958)(“It is hardly a novel perception that "compelled disclosure of affiliation with groups engaged in advocacy may constitute [an] effective . . . restraint on freedom of association."); see also, Shelton v. Tucker, 364 U.S. 479, 490 (1960)(prohibiting compelling teachers to disclose group memberships).

${ }^{169} 514$ U.S. 334 (1995).

190 McIntyre, 514 U.S. at $341-42$. 
time, reveal associational tendencies as thoroughly as a membership list." ${ }^{\text {191 }}$ These facts can only inhibit the public conduct of those who want to remain anonymous.

There is little doubt that public camera surveillance can infringe First Amendment values. When those values are implicated, government should have to justify the presence of the cameras on a meaningful law enforcement ground; even those cases that reject First Amendment arguments against camera surveillance seem to find the existence of a legitimate government objective important. ${ }^{192}$ Again, however, that conclusion only provides constitutional protection for expressive conduct, a category that the Court has defined rather narrowly. Other caselaw broadens that protection considerably.

\section{Freedom of Movement and Repose}

Derived from the Due Process Clause, the right to travel is another fundamental right that might be compromised by public camera surveillance. As far back as the turn of the twentieth century, the Supreme Court stated: "Undoubtedly the right of locomotion, the right to remove from one place to another according to inclination, is an attribute of personal liberty, and the right, ordinarily, of free transit from or through the territory of any state is a right secured by the 14th Amendment and by other provisions of the Constitution."193 This sentiment was echoed over a half century later in Kent $v$. Dulles, ${ }^{194}$ a case that dealt with restrictions on travel overseas but uses

191 McAdams, supra note 139 , at 322.

192 Reporters Comm. for Freedom of the Press v. A.T.T., 593 F.2d 1030 (D.C. Cir. 1978)(“[P]hysical surveillance consistent with Fourth Amendment protections and in connection with a bona fide law enforcement investigation does not violate First Amendment rights, even though it may be directed at communicative or associational activities, and even though it may inhibit those activities.")(emphasis added); see also Grayned v. City of Rockfort, 408 U.S. 104, 115 (1972) ("the right to use a public place for expressive activity may be restricted only for weighty reasons"); Alliance to End Repression v. Chicago, 627 F. Supp. 1044, 1056 (1985)("Without any reasonable suspicion of criminal conduct, the court cannot conceive of any remotely compelling interest the City has in recording which political activities an individual chooses to involve herself in ...").

189 Williams v. Fears, 179 U.S. 270, 274 (1909).

194357 U.S. 116 (1958). 
language relevant to domestic travel as well:

Freedom of movement across frontiers in either direction, and inside frontiers as well, was a part of our heritage. Travel abroad, like travel within the country, may be necessary for a livelihood. It may be as close to the heart of the individual as the choice of what he eats, or wears, or reads. Freedom of movement is basic in our scheme of values.... [O]utside areas of plainly harmful conduct, every American is left to shape his own life as he thinks best, do what he pleases, go where he pleases. ${ }^{196}$

As this language suggests, the "right of locomotion" is not limited to expressive actions. ${ }^{196}$ In contrast to the First Amendment, this right is important for economic and social reasons as well as political ones. The Kent Court went on the state explicitly that "[f]reedom of movement also has large social values," including support of activities "close to the core of personal life [such as] spending hours with old friends. ${ }^{\$ 197}$ The right to travel was recently reaffirmed as a guarantee implicit in the Privileges and Immunities Clause of the Fourteenth Amendment. ${ }^{198}$

Closely related to the right to freedom of public movement is the right to repose, or stasis, in public. In Chicago $v$. Morales, ${ }^{199}$ a four-member plurality of the Court stated that

the freedom to loiter for innocent purposes is part of the 'liberty' protected by the Due Process Clause of the Fourteenth Amendment.... Indeed, it is apparent that an individual's decision to remain in a public place of his choice is as much a part of his liberty as the freedom of movement

190 Kent, 357 U.S. at 126 (quoting Zechariah ChafEe, JR., Three Human RIGHTS IN THE CONSTTIUTION OF 1787197 (1956)); see also Shapiro v. Thompson, 394 U.S. 618, 629 (1969)("our constitutional concepts of personal liberty unite to require that all citizens be free to travel throughout the length and breadth of our land uninhibited by statutes, rules, or regulations which unreasonably burden or restrict this movement.").

${ }_{196}$ See Williams v. Fears, 179 U.S. 270, 274 (1900)(referring to the right to move from place to place as the "right of locomotion").

197 Kent, 357 U.S. at 126.

198 Saenz v. Roe, 526 U.S. 489, 502-503 (1999).

109527 U.S. 41 (1999). 
inside frontiers that is "a part of our heritage," or the right to move "to whatsoever place one's own inclination may direct" identified in Blackstone's Commentaries.

The Court has been emphatic about striking down vagrancy statutes that trench on this right to repose. ${ }^{201}$

How might these interests in locomotion and stasis-the "freedom to walk, stroll, or loaf"202 -be affected by the panoptic eye of the camera? Although no courts have directly addressed this issue, the few that have dealt with analogous facts are wary of camera use that affects these interests, at least when there is also proof of some animus. In Goosen $v$. Walker, ${ }^{203}$ for instance, a Florida court enjoined the defendant from further videotaping of his neighbors (with whom he had previously had altercations), concluding that his videotaping of them in their yard and adjoining areas, on two to four occasions over a four month period, constituted "stalking. ${ }^{204}$ In State v. Baumann et al. ${ }^{205}$ the court upheld an order that permanently enjoined thirty-two individuals from photographing or videotaping people entering and leaving an abortion clinic under circumstances that exhibited "an intent to harass, intimidate or interfere with any person seeking access to or departing from such facility. ${ }^{206}$

200 Morales, 527 U.S. at 53-54 (citations omitted).

201 Id., at 64; Kolender v. Lawson, 461 U.S. 32 (1983)(invalidating California statute requiring individuals who loiter or wander the streets to present police officers with identification upon request); Papachristou v. Jacksonville, 405 U.S. 156 (1972)(invalidating Jacksonville vagrancy ordinance); Coates v. Cincinnati, 402 U.S. 611 (1971)(invalidating Ohio ordinance making it unlawful for three or more people to assemble in certain public areas in a manner annoying to others).

202 Roe v. Wade, 410 U.S. 179, 213 (1973)(Douglas, J., concurring).

203714 So.2d 1149 (Fla. Dist. Ct. App.1998).

204 Goosen, 714 So.2d at 1150.

206 No. 92-3198, 1995 WL 78289 (Wis.Ct.App.1995).

206 Baumann, 1995 WL 78289, at *2; see also Pro-Choice Network of Western New York, 799 F.Supp. 1417, 1437-39 (W.D.N.Y.1992)(cautioning that if defendants continue to use cameras to intimidate women entering abortion clinics, the court would not hesitate to restrict defendants' use of cameras); Planned Parenthood v. Aakhus, 17 Cal. Rptr.2d 510, 515 (Cal. Ct. App. 1993 (photographing and videotaping abortion clinic clients violated the right to privacy under the California Constitution); Chico Feminist Women's Health Ctr. v. Scully, 256 Cal. Rptr. 194, 196-97 (Cal. Ct. App. 1989)(upholding an injunction against abortion protest- 
Even the media, normally left unrestrained by courts concerned about freedom of the press, can go too far. In Wolfson $v$. Lewis, ${ }^{207}$ for instance, the court held that "a persistent course of hounding [by reporters], even if conducted in a public or semi-public place, may nevertheless rise to the level of invasion of privacy based on intrusion upon seclusion." ${ }^{208}$ It then issued an injunction against investigative news reporters who had repeatedly sought to videotape and eavesdrop on a business executive and his family in and outside their home and place of work. ${ }^{209}$

In Goosen the videotaping inhibited repose (in the targets' backyard), in Baumann it inhibited movement (to and from the abortion clinic), and in Wolfson it inhibited both (around the house and workplace and going to and from those locations). In all three, the videotaping was actionable. That suggests that public surveillance, even when targeting actions not protected by the First Amendment, can infringe interests in locomotion and stasis to a legally cognizable degree.

At the same time, all three courts required proof that those who wielded the cameras intended to harass. That type of motivation will usually be absent when government watches with public surveillance cameras. Using the terminology of these cases, to say that the government's camera surveillance of people walking the streets constitutes the malicious-sounding acts of "stalking," "intimida[tion] or interfere[nce]," or "a persistent course of hounding" will normally be an exaggeration.

A crucial fact about each of these three cases, however, is that all of the defendants were raising First Amendment

ers photographing license plates and people entering or leaving an abortion clinic). Although these decisions were based on varying considerations, including, as in Aakhus, informational privacy, the immediate harm was the unjustifiable inhibition of the plaintiffs' ability to go about their business.

207924 F.Supp. 1413 (E.D.Pa.1996),

208 Wolfson, 924 F. Supp. at 1420; see also Galella v. Onassis, 533 F.Supp. 1076 (S.D.N.Y. 1982)("under certain circumstances, surveillance may be 80 'overzealous' as to render it actionable. It does not strain credulity or imagination to conceive of the systematic 'public' surveillance of another as being the implementation of a plan to intrude on the privacy of another")(citing Nader v. General Motors Corp., 255 N.E.2d 765, 771, 772 (1970)).

209 Wolfson, 924 F.Supp. at $1432-33$. 
claims. That is, they were asserting that camera-users, whether lay or press, have a First Amendment right to videotape public events, ${ }^{210}$ an assertion that the courts in these cases accepted. Given the nature of the right the injunctions would infringe, the courts had to find a compelling justification for them-illegitimate harassment. ${ }^{211}$ If, on the other hand, public videotaping were not considered a First Amendment activity, such proof would not be considered necessary.

The latter observation has significant implications for government-run CCTV. Unlike its citizens, the government does not have a First Amendment right to train cameras on the populace. Accordingly, an absence of ill-will on the part of government agents who operate the cameras should not immunize them from scrutiny. Instead, the issue should be, straightforwardly, whether government camera surveillance trenches on the right to movement or repose.

It clearly does, for reasons stated in Part I. People ogled by cameras may choose to walk rather than run; move on rather than loiter; even avoid going where they would like to go altogether. While government surveillance may not amount to intentional stalking or hounding, it is not innocuous. Indeed,

210 See Goosen, 714 So.2d at 1149 (appellant "argues that the injunction is unconstitutional because it violates the First Amendment"); Baumann, 1995 WL 78289 , at *4 ("Appellants claim that the 'non-blockading' provisions of the injunction are 'invalid content-based regulations not narrowly drawn to serve the compelling state interest' and, therefore, violative of rights guaranteed under the First Amendment."); Wolfson, 924 F.Supp. at 1415 ("Defendants contend that they did not invade plaintiffs' privacy and that their conduct investigating the salaries of U.S. Healthcare executives is protected by the First Amendment to the United States Constitution.").

${ }^{211}$ Goosen, 714 So.2d at 1150 ("While the First Amendment confers on each citizen a powerful right to express oneself, it gives the [citizen] no boon to jeopardize the health, safety, and rights of others")(alteration in original)(quoting Bouters v. State, 659 Sol2d 235, 237 (Fla. 1995); Baumann, 1995 WL 78289, at *7 ("[n]o matter how public the setting or the subject, there is no First Amendment right to use a camera as a tool of intimidation"); Wolfson, 924 F.Supp. at 1433 ("A reasonable jury would likely conclude that it is difficult to understand how hounding, harassing, and ambushing the Wolfsons would advance the newsworthy goal of exposing the high salaries paid to U.S. Healthcare executives or how such conduct would advance the fundamental policies underlying the First Amendment which include providing information to enable members of society to cope with the exigencies of their period."). 
whatever its intent, it can have a similar effect to stalking, given its inhibition of public locomotion. ${ }^{212}$

That conclusion does not dictate that such surveillance be prohibited, of course. It simply requires, again, that the government demonstrate a legitimate reason for its actions. As the Supreme Court has said, "restrictions on the right to travel .. . may not be achieved by means which sweep unnecessarily broadly and thereby invade the area of protected freedoms. ${ }^{213}$

\section{The Right to Privacy}

A third constitutional basis for regulating CCTV comes from the general right to privacy which is found, depending upon the decision announcing the right, in the penumbras of the First, Third, Fourth and Fifth Amendments, the Fourteenth Amendment's Due Process Clause, or the Ninth Amendment's reservation of rights to the states. ${ }^{214}$ The Supreme Court has relied on this right (which in the caselaw is often subsumed under a "due process right to liberty") in striking down laws banning abortion, ${ }^{215}$ interracial marriage, ${ }^{216}$ purchase and use of contraceptives, ${ }^{217}$ and the like. ${ }^{218}$ As

213 See William A. Stuntz, The Distribution of Fourth Amendment Privacy, 67 GEO. WASH. L. REV. 1265, 1277 (1999)(noting that stakeouts "sometimes do involve monitoring the movements of a given suspect ... over an extended period of time," which is "roughly the equivalent of being stalked.").

213 Aptheker v. Secretary of State, 378 U.S. 500, 507-08 (1964)(quoting NAACP v. Alabama ex rel. Flowers, 377 U.S. 288, 307 (1964)). Aptheker went on to find unconstitutional the State Department's revocation of passports held by members of the Communist Party because "[t]he prohibition against travel is supported only by a tenuous relationship between the bare fact of organizational membership and the activity Congress sought to proscribe." Id. a 514 .

214 See ERwIn Chemerinsky, Constitutional Law: Principles and Policies 785, 790 (2d ed. 2002)(noting these differing bases for the privacy right).

215 Roe v. Wade, 410 U.S. 113, 153 (1973)(“[The] right to privacy, whether it be founded in the Fourteenth Amendment's conception of personal liberty and restrictions upon state action, as we feel it is, or, . . . in the Ninth Amendment's reservation of rights to the people, is broad enough to encompass a woman's decision whether or not to terminate her pregnancy.").

216 Loving v. Virginia, 388 U.S. 1,12 (1967)(stating that antimiscegenation laws "surely ... deprive all the State's citizens of liberty without due process of law").

217 Eisenstadt v. Baird, 405 U.S. 438, 453 (1972)(holding that a law which prohibited sale of contraceptives to unmarried people was unconstitutional be- 
with the rights to freedom of movement and repose, the right to privacy is not limited to protection of expressive conduct.

There are at least two versions of the right to privacy, one focusing on protection-of-personhood and the second on freedom-from-normalization. The personhood version views the right to privacy as a means of ensuring individuals are free to define themselves. It protects against state interference in decisions that are "central to the personal identities of those singled out." ${ }^{\text {219 }}$ The anti-normalization version, in contrast, focuses on the extent to which the government action standardizes lifestyles. ${ }^{220}$

The manner in which public camera surveillance affects our ability to define ourselves has already been suggested, but a recent article by Andrew Taslitz fleshes out the analysis. Privacy, Taslitz notes, enables us to present to others only those parts of our selves that we want them to see. ${ }^{221}$ That in turn enables us to put forth different versions of our selves in different contexts, with those at the job seeing one side, those at home seeing another, and those at social events or athletic competitions seeing still another. ${ }^{222}$ Even in public, we expect privacy to play its role as a facilitator of self-definition. Taslitz quotes Michael Riesman's observation that “[p]eople may look, but they are expected to look at those parts that the owner of the exoself wants them to look at, at appropriate times and

cause, "[i]f the right to privacy means anything, it is the right of the individual, married or single, to be free from unwarranted governmental intrusion into matters so fundamentally affecting a person as the decision whether to bear or beget a child"); Griswold v. Connecticut, 381 U.S. 479, 485 (1965)(holding that a law which prohibits sale and use of contraceptives infringes "penumbral rights of privacy and repose").

218 See generally ChEMERINSKY, supra note 214, at 768-827.

219 Jed Rubenfeld, The Right Of Privacy, 102 HARV. L. REV. 737, 752-54 (1989).

220 Id. at $783-87$ \& 794 ("The point is not to save for the individual an abstract and chimerical right of defining himself; the point is to prevent the state from taking over, or taking undue advantage of, those processes by which individuals are defined in order to produce overly standardized, functional citizens.").

221 Andrew E. Taslitz, The Fourth Amendment in the Twenty-First Century: Technology, Privacy, and Human Emotions, 65 LAW \& CONTEMP. PROBS. 125, 152 (2002).

223 Id. 
following certain procedures."22s Ogling, staring, or merely paying more than fleeting attention to strangers in public is considered impolite and uncivil, because it crosses personal boundaries and requires revelation of more than we are used to revealing. ${ }^{224}$ Such conduct prevents us from retaining control over how we present ourselves.

Thus, Taslitz summarizes, "[w]ho looks at us, how, how long, and for what purposes matter. ${ }^{\text {"225 }}$ With respect to camera surveillance in particular, he concludes:

[w] hen technology enables the government to stare with an ever-vigilant and suspicious eye, the boundaries of the self may partly dissolve, reconstructed in the image chosen by Leviathan. ... Regulation [of this technology] preserves the idea of a diverse, noisy America, where citizens are free to get lost in the crowd and where their sense of self stems from their chosen affiliations and actions rather than from the allseeing gaze of the state. ${ }^{\text {226 }}$

As this last statement suggests, because a substantial part of our personality is developed in public venues, through rituals of our daily lives that occur outside the home and outside the family, cameras that stultify public conduct can stifle personality development. ${ }^{227}$

The second version of the right to privacy, championed by Jed Rubenfeld, pushes toward the same conclusion, but from a different direction. Rubenfeld debunks the personhood version of privacy-again, the notion the Court's privacy decisions should be construed as means of preserving an enclave of

${ }^{223}$ Id. at 169 (quoting Michael Reisman, Law in Brief Encounters 31 (1999)).

224 Id.

225 Id. at 171 .

226 Id. at 171-72.

237 Cf. Roberts v. United States Jaycees, 468 U.S. 609, 619 (1984)(anonymity "safeguards the ability independently to define one's identity that is central to any concept of liberty"); see generally Lee Tien, Who's Afraid of Anonymous Speech: McIntyre and the Internet, 75 ORE. L. REV. 117, 120 (1996)("anonymity is useful for constituting individual and group identity in interaction."); Robert Post, The Social Foundations of Privacy: Community and Self in the Common Law of Tort, 77 CAL. L. Rev. 957, 964 (1989)("An intrusion on privacy is intrinsically harmful because it is defined as that which injures social personality."). 
decisionmaking (such as abortion or marriage) that allows the individual to develop one's identity and exercise one's autonomy. Rather, he argues that these types of cases deal with "the fundamental freedom not to have one's life too totally determined by a progressively more normalizing state." ${ }^{\text {228 }}$ A prohibition on abortion and use of contraceptives is unconstitutional, he says, not because decisions about those issues are necessary to self-definition, but because together they force women to be mothers; ${ }^{229}$ a prohibition on interracial marriages is unconstitutional not because it infringes one's autonomy to do what one wants, but because it coerces people into having homogenous children. ${ }^{230}$ The "danger" of such laws, Rubenfeld states,

is a particular kind of creeping totalitarianism, an unarmed occupation of individuals' lives. That is the danger of which Foucault as well as the right to privacy is warning us: a society standardized and normalized, in which lives are too substantially or too rigidly directed. That is the threat posed by state power in our century. ${ }^{231}$

Note in particular Rubenfeld's use of Foucault. Here Rubenfeld is referring to the same Foucaultian concerns identified earlier in this article about the modern state's ability, "through expanded technologies and far more systematic methods of acculturation, ... to watch over and shape our lives, to dispose and predispose us, and to inscribe into our lives and consciousnesses its particular designs." ${ }^{\text {232 }}$ Although Rubenfeld does not speak of government surveillance directly, his argument that the right to privacy has been and should be ranged against government actions that promote "normalization" has significant implications for that particular type of state action. As Simon Davies commented in describing the effect of CCTV and other forms of technological surveillance, "[$t]$ he society we are developing now . . . is a Brave New World dominated not so much by tyranny as by a deadening political and cultural phe-

\footnotetext{
228 Rubenfeld, supra note 219 , at 784 .

229 Rubenfeld, supra note 219 , at 788-91.

230 Rubenfeld, supra note 219, at 791-92.

${ }^{231}$ Rubenfeld, supra note 219 , at 784 .

$2 s 2$ Rubenfeld, supra note 219 , at 775 .
} 
nomenon that Ralph Nader calls 'harmony ideology' [the coming together of opposing ideologies and beliefs into manufactured consensus]. ${ }^{\text {,233 }}$ If CCTV contributes to that effect-and the literature linking panopticism and anticipatory conformity suggests it does ${ }^{234}$-it impinges directly on the privacy right that Rubenfeld believes the Court's decisions establish, and should be regulated accordingly.

\section{Freedom from Unreasonable Searches and Seizures}

None of these arguments about a constitutional basis for regulating government camera surveillance rely directly on the Fourth Amendment. Surely if CCTV implicates the First Amendment, the due process rights to movement and repose, or the general right to privacy, it ought to implicate the Fourth Amendment as well. Yet the Supreme Court's caselaw construing the scope of that amendment leaves little purchase for such a position.

In Katz $v$. United States, ${ }^{235}$ the seminal decision defining the threshold of the Fourth Amendment, the Supreme Court held that government agents who bugged a phone booth had engaged in a Fourth Amendment search. ${ }^{236}$ Even though previous cases had held that the Fourth Amendment is not implicated unless a trespass occurs on a constitutionally protected area" (i.e., a house, person, paper or effect), ${ }^{237}$ and even though the bugging in this case involved neither a trespass or a protected area, the Court reasoned that "what a person seeks to preserve as private, even in an area accessible to the public,

\footnotetext{
2ss Davies, supra note 38 , at $144 \&$ n.1.

234 See supra text accompanying notes 131-137.

235389 U.S. 347 (1967).

${ }^{236} \mathrm{Katz}, 389$ U.S. at 353.

237 See, e.g., Silverman v. United States, 365 U.S. 505, 510 (1961)(stating that its holding that use of a spike mike inserted in defendant's wall is a search was "based upon the reality of an actual intrusion into a constitutionally protected area"); Olmstead v. United States, 277 U.S. 438, 464 (1928)(in holding that wiretapping is not a search, stating that "[ $t$ ]he evidence was secured by the use of the sense of hearing and that only. There was no entry of the houses or offices of the defendants.").
} 
may be constitutionally protected."

The majority opinion also stated, however, that "what a person knowingly exposes to the public ... is not a subject of Fourth Amendment protections. "2239 This is the sentiment upon which the Court relied in Knotts when it held that use of a beeper to monitor movement on the public highway is not a search. ${ }^{240}$ As the lower court caselaw previously surveyed indicated, application of this formulation to CCTV is likely to produce the same result. ${ }^{241}$ One could perhaps argue that one did not "know" certain public conduct was exposed to the camera, but that strategy is unlikely to work under most circumstances. First, we are talking about overt, not covert, camera use, accompanied by signs announcing its presence. Second, the Court has indicated that government need not show actual knowledge of exposure to nullify Fourth Amendment protection. If a target should have known public exposure might occur, the Court has held, one assumes the risk of such exposure and loses Fourth Amendment protection. ${ }^{242}$

That's not all. Time and again, the Court has emphasized the distinction between mere observation and physical intrusion. ${ }^{24}$ Thus, police observation from a public vantage point is not a search, even if the area observed is the curtilage, tradi-

${ }^{238} \mathrm{Katz}, 389$ U.S. at 351.

259 Id.

${ }^{210}$ United States v. Knotts, 460 U.S. 276, 285 (1983)(“A police car following Petschen at a distance throughout his journey could have observed him leaving the public highway and arriving at the cabin owned by respondent, with the drum of chloroform still in the car.").

242 See supra note 106.

242 Smith v. Maryland, 442 U.S. 735, 744 (1979)(holding that police did not carry out a search when they obtained phone numbers dialed by Smith from phone company because, by dialing the numbers, Smith "assumed the risk that the company would reveal to police the numbers he dialed.").

24 See, e.g., Bond v. United States, 529 U.S. 334, 337 (2000)(in holding that feeling soft luggage was a search, Court stated “[p]hysically invasive inspection is simply more intrusive than purely visual inspection"); Dow Chem. Co. v. U.S. 476 U.S. 227, 237 (1986)(in holding that EPA photography of a chemical plant's curtilage from a plane was not a search, stating that "[a]ny actual physical entry by EPA into any enclosed area would raise significantly different questions"); California v. Ciraolo, 476 U.S 207, 213 (1986)(in holding that looking into a backyard from an airplane is not a search, stating "[t]he observations took place within public navigable airspace ... in a physically nonintrusive manner"). 
tionally considered to be part of the home. ${ }^{244}$ Indeed, even if the target is the home itself, the degree of physical intrusion plays an important role. In the Court's recent decision in Kyllo $v$. United States, ${ }^{245}$ the Court held that use of a thermal imager to detect heat sources inside a house is a search, whether or not the government agent using the imager is on public property. ${ }^{246}$ However, in dictum the Court exempted from Fourth Amendment protection naked eye surveillance of the home that does not require "physical intrusion into a constitutionally protected area," as well as any technological surveillance that merely replicates what such naked eye viewing would observe. ${ }^{247}$ To the extent CCTV merely replicates what naked observation from a public vantage point could view, it is unlikely to merit Fourth Amendment protection apparently even when it allows viewing of the interior of the home.

Similarly, despite CCTV's inhibition of the right to movement, it is unlikely to amount to a Fourth Amendment "seizure" under the Court's cases. Such a seizure occurs when the government, "by means of physical force or show of authority, has in some way restrained the liberty of a citizen, ${ }^{, 248}$ or at least when "a reasonable person [would not be] at liberty to ignore the police presence and go about his business. ${ }^{249} \mathrm{Al}-$ though the latter formulation could in theory contemplate the effects of CCTV, which may well retard people's ability to go about their business, the Court has twice held that police do

24 See Dow Chem., 476 U.S. at 236-37 (upholding aerial surveillance of business curtilage); Ciraolo, 476 U.S. at 213 (noting that not all police observation of the area within curtilage is disallowed).

24533 U.S. 27 (2001).

$246 \mathrm{Kyllo}, 533$ U.S. at 40.

217 Id. ("Where . . . the Government uses a device that is not in general public use to explore details of the home that would previously have been unknowable without physical intrusion, the surveillance is a search."). I have pointed out that this language could be read to mean "that if the activity observed could be seen with the naked eye without physical intrusion into the constitutionally protected areas of home or curtilage, then police may exploit any technology-generally used or not-without implicating the Fourth Amendment." Christopher Slobogin, Peeping Techno-Toms and the Fourth Amendment: Seeing Through Kyllo's Rules Governing Technological Surveillance, 86 MNN. L. REv. 1393, 1419 (2002).

248 Terry v. Ohio, 392 U.S. 1, 20 n. 16 (1968).

249 Michigan v. Chesternut, 486 U.S. 567, 569 (1988). 
not effect a seizure if they conspicuously follow or chase an individual without bringing the individual to a stop. ${ }^{250}$ Under this caselaw, it would be difficult to argue that monitoring an individual with a camera is a seizure.

But what about the fact that CCTV allows recording of one's public activity? It has been argued that even if we assume the risk that others will view our public conduct, we do not assume the risk that our public actions will be reduced to a photograph or film that can be "scrutinized indefinitely and disseminated to an unintended audience" and that "allows the viewer to discern details that would not have been apparent to a casual observer. ${ }^{251}$ This argument too is plausible, but once again the Court's cases are very unhelpful as support. In On Lee $v$. United States, ${ }^{252}$ the Supreme Court held that the Fourth Amendment is not implicated when the government overhears and records an individual's conversation with an informer through a body bug worn by the informer, ${ }^{253}$ a holding it later affirmed. ${ }^{254}$ If we have to assume the risk that our acquaintances are secretly recording our conversations, we probably also have to assume the risk that overt CCTV will be recording our public conduct.

There are at least three lines of attack against this view of the Fourth Amendment's (non) application to CCTV. The first, of course, is to show that the Court's public exposure/assumption of risk approach to the Fourth Amendment is misguided. That approach has already produced intriguing scholarship (which the Court unfortunately has ignored), ${ }^{255}$ and no such

${ }^{250}$ See Chesternut, 486 U.S. at 574 (holding police car driving alongside defendant not a seizure); California v. Hodari, 499 U.S. 621, 629 (1991)(police chase of defendant not a seizure).

251 Sim, supra note 140, at 470-71; see also, Andrew J. McClurg, Bringing Privacy Law Out of the Closet: A Tort Theory of Liability for Intrusions in Public Places, 73 N.C. L. REv. 989, 1041-44 (1995).

252343 U.S. 747 (1952).

250 On Lee, 343 U.S. at 753 (the defendant "was talking confidentially and indiscreetly with one he trusted, and he was overheard .... due to aid from a transmitter and receiver, to be sure, but with the same effect on his privacy as if agent Lee had been eavesdropping outside an open window.").

254 United States v. Caceres, 440 U.S. 741 (1979).

255 See, e.g., Scott E. Sundby, "Everyman"s Fourth Amendment: Privacy or Mutual Trust Between Government and Citizen?, 94 ColuM. L. Rev. 1751 (1994) 
effort will be made in this article. The second method of undermining the apparent judicial acquiescence to unregulated public surveillance is to accept the Court's formulation of the Fourth Amendment's threshold, but to distinguish its caselaw by insisting, for instance, that CCTV does effectuate a "seizure" because of its effect on movement, or that it does constitute a "search" when it creates a record because that is not a risk we assume when we go out in public. The likely futility of this line of argument has already been suggested, and in any event will not be pursued here. ${ }^{256}$

The third line of attack, which I do undertake here, is to take seriously the Court's admonition that the Fourth Amendment's scope is ultimately defined by "expectations of privacy society is prepared to recognize as reasonable." This language, first found in Justice Harlan's concurring opinion in $K_{a t z} z^{257}$ and since elevated to litmus test status (superceding even the "knowing exposure" language), ${ }^{258}$ suggests an empirical inquiry into society's views about privacy. If the Court really means to equate Fourth Amendment protections with the expectations of privacy that society is prepared to recognize as reasonable, it should not ignore society's views on that topic. The next section briefly describes one effort at such an inquiry, which resulted in findings that support the Fourth Amendment's application to CCTV.

(arguing that inculcation of trust between citizens and government, not privacy, should be the core interest protected by the Fourth Amendment); William J. Stuntz, Privacy's Problem and the Law of Criminal Procedure, 93 MICH. L. REV. 1016 (1995) (arguing that coercion, not privacy, should be the principal focus of Fourth Amendment protection); Tom Clancy, What Does the Fourth Amendment Protect: Property, Privacy, or Security?, 33 WAKE FOREST L. REv. 307 (1998) (arguing that the Fourth Amendment protects security); see also R. v. Duarte, 1 S.C.R. 30, paras. 25, 26 (1990), where the Canadian Supreme Court held that reasonable expectations of privacy are to be defined by standards of privacy that persons can expect to enjoy in a "free society," not by assumption of risk analysis.

256 But see supra text accompanying note 109.

${ }^{257}$ Katz v. United States, 389 U.S. 347, 361 (Harlan, J., concurring).

2sa Wayne R. LaFave, I Search and Seizure: A Treatise on the Fourth AMENDMENT 384 (3d ed. 2002)(“[L]ower courts attempting to interpret and apply Katz quickly came to rely upon the Harlan elaboration as ultimately did a majority of the Supreme Court."). 


\section{An Empirically-Based Case for Fourth Amendment Regulation of CCTV}

Basing Fourth Amendment protection on society's expectations of privacy requires answering several questions. First, how can we discover these expectations? Second, what are they? Third, in what sense are they relevant to Fourth Amendment analysis?

\section{Sources of Society's Privacy Expectations Vis-a-vis CCTV}

How does one determine society's views about whether CCTV threatens privacy? One source is the positive law governing public camera surveillance by entities other than the government. If such surveillance is a crime or a tort, then it might be said to infringe on expectations of privacy considered important by society.

At first glance, both case law and statutory law appear to indicate quite the opposite. As noted previously, ${ }^{259}$ the court decisions that address overt videotaping of public activity by private actors generally require a significant degree of maliciousness before relief will be granted. ${ }^{260}$ Statutory law regarding public camera use is also sparse. Recall that only Arizona has a statute specifically dealing with public videotaping by private parties, ${ }^{261}$ in contrast to the many states that prohibit or significantly limit use of cameras to capture activities within the home. ${ }^{262}$

${ }^{259}$ See supra text accompanying notes 203-10.

260 See also, William L. Prosser, Privacy, 48 CAL. L. Rev. 383, $391-92$ (1960) (asserting that the tort of privacy invasion is not implicated when one takes a photograph of a person in a public place, "since this amounts to nothing more than making a record, not differing essentially from a full written description, of a public sight which any one present would be free to see"); Sheldon Halpern, The Traffic in Souls: Privacy Interests and the Intelligent Vehicle-Highway Systems, 11 SANTA ClaRA CoMputer \& HIGH TECH. L. J. 45, 59-60 (1995)(noting that "to the limited extent that ... observation per se, absent publication ... has been deemed actionable, it has been surreptitious and offensively intrusive").

${ }_{201}$ See supra notes $100-02$ and accompanying text.

260 See, e.g., statutes cited supra note 104; see also State Hidden Camera Statutes at http://www.rcfp.org/handbook (listing eleven other states that "expressly prohibit the unauthorized installation or use of cameras in private places."). 
This paucity of positive law regulating public camera use probably says little about society's attitudes toward CCTV, however. That is because there is no real private analogue to government-run CCTV. No entity other than the government engages in concerted, overt surveillance of the public streets using cameras. If private companies or individuals began filming public spaces twenty-four hours a day using zoom and nightvision capacity in an effort to discern, say, people's shopping, exercise, eating and drinking patterns, both tort and statutory regulation would probably be forthcoming. ${ }^{263}$

A second source of information about society's views concerning the intrusiveness of CCTV comes from polls directly asking about attitudes toward CCTV. Although to date there are few polls of that type in the United States, ${ }^{264}$ researchers in the United Kingdom have conducted several. All of them show significant public support for CCTV, well-above $60 \%$. $^{265}$ Yet the most sophisticated poll of this type also indicated some concern about the practice, despite its prevalence in that country. More than $50 \%$ of the respondents felt that some entity other than the government or private security firms should be responsible for the installation of CCTV in public places, $72 \%$ agreed that "these cameras could easily be abused and used by

26s Somewhat analogous to such regulation is the federal government's effort to limit private companies' accumulation of data about habits and personal characteristics from credit reports, government records, driver's licenses, video rentals, student records, health records, children's Internet activities, and banking, insurance, and investment company records. Although these statutory efforts at regulation are not particularly effective, they represent a desire to restrict the extent to which private entities can obtain information that we have disclosed to people outside our immediate circle and that sometimes are even a matter of "public record." See generally Daniel J. Solove, Privacy and Power: Computer Databases and Metaphors for Information Privacy, 53 STAN. L. REv. 1393, 1440-44 (2001) (describing the legislation and its flaws).

204 A Harris poll conducted in the United States in October, 2002, did indicate that $63 \%$ of those surveyed were in favor of "increased video surveillance" of public places like airports. Ken Kaye, High Tech Security Gets Tests at Airports, FT. LAUdERDAle Sun-Sentinel, Jan. 20, 2002, at A1.

${ }^{205}$ See Taylor, supra note 48, I 16 (reporting polling results that found between 69 and $95 \%$ in favor of the cameras). But see supra note 144, describing a study leading the author to question the higher figures on the ground that those surveyed were usually plied with positive statements about CCTV beforehand. 
the wrong people," $39 \%$ believed that the people in control of these systems could not be "completely trusted to use them only for the public good," and 37\% felt that "in the future, cameras will be used by the government to control people." 266 More than $10 \%$ of the respondents believed that CCTV cameras should be banned. ${ }^{267}$ Americans, who tend to be more concerned about government power than the British, would probably be even more hostile to CCTV.

More importantly, poll results showing favorable attitudes toward CCTV fail to distill feelings about intrusiveness from feelings about security. Those who say they do not mind government camera surveillance may be allowing its perceived effectiveness at preventing crime to submerge their discomfort about being watched. That attitude makes sense; indeed, if the threat of harm to be prevented is high, a wide range of people will welcome policing techniques much more intrusive than camera surveillance, as reactions to the events of September 11 have shown. ${ }^{268}$ Under the Fourth Amendment, however, that type of balancing/reasonableness calculus is not supposed to inform the initial question of whether something is a search or seizure, but rather only whether something that is a search or seizure is justified. ${ }^{269}$

To isolate the intrusiveness question more cleanly with respect to CCTV, I used a methodology that Joseph Schumacher and I developed in a previous study about the Fourth Amendment's threshold. ${ }^{270}$ In that study we asked people how they rated the intrusiveness of a number of police

${ }^{268}$ Davies, supra note 38, at 152 (describing a British Home Office survey conducted in 1992).

288 Id.

${ }_{288}$ See supra note 95.

${ }^{260}$ See Christopher Slobogin, Let's Not Bury Terry: A Call for Rejuvenation of the Proportionality Principle, 72 ST. JoHN's L. REv. 1053, 1072 (1998)(asserting that using balancing analysis to define search or seizure "is barred by the language of the Fourth Amendment itself. That provision's prohibition on unreasonable searches and seizures' applies the reasonableness test only after something has been labeled a search or seizure.").

${ }^{270}$ Christopher Slobogin \& Joseph E. Schumacher, Reasonable Expectations of Privacy and Autonomy in Fourth Amendment Cases: An Empirical Look at "Understandings Recognized and Permitted by Society," 42 DUKE L. J. 727 (1993). 
investigative techniques. That approach permits a better assessment of how people feel about the effect each technique has on privacy, because it produces a hierarchy of perceived intrusiveness; even people who are willing to sacrifice most or all of their privacy interests to fight crime evaluate the privacy-invading impact of different crime fighting techniques differently. Thus, for instance, on average our subjects rated a body cavity search as the most intrusive of the scenarios and a search of a public park as the least, and a search of a bedroom as more intrusive than a frisk. ${ }^{271}$ From these types of results, one can draw useful conclusions about the relative magnitude of people's expectations of privacy with respect to a given technique such as CCTV.

Unfortunately, the fifty scenarios in the Slobogin \& Schumacher study did not include any involving camera surveillance. The study reported here fills that gap.

\section{The Study}

The survey form developed for this study was similar to the form used in the original Slobogin and Schumacher study with a few notable exceptions. First, it contained only twenty relevant scenarios, ${ }^{272}$ not fifty. Second, it included two or three scenarios (depending upon which of three survey versions the subject received) describing various forms of camera surveillance. The three basic camera surveillance scenarios were police use of cameras with zoom capacity at national monuments, police use of cameras with zoom capacity at airports and other transportation centers, and police use of cameras with zoom capacity at 300-yard intervals along a public street. The latter scenario had two variations: overt versus hidden cameras, and destruction of records within 96 hours versus indeterminate retention of records which could be released to government agencies and the media as needed. Also new with this survey form were scenarios involving other types of techno-

271 Id. at 738-39 (Table 1).

272 The survey actually contained twenty-five scenarios but the results pertaining to several of them (involving, e.g., searches of personal diaries and car trunks) do not add appreciably to the discussion and are not reported here. 
logical surveillance (i.e., beepers and "see-through" devices ${ }^{279}$ ) and a scenario describing a police officer following an individual on the public street. ${ }^{27}$

The survey was completed by 190 people called for jury duty in Gainesville, Florida. Because Florida jury pools are randomly selected from voter registration lists, this sample was a relatively diverse group of people. As in the earlier study, ${ }^{275}$ the subjects were told to assume that, in each scenario, the police were looking for evidence of crime but that the target of the police action had not engaged in any criminal activity. In other words, the subjects were told to assume the individuals in the scenarios were innocent, an assumption that is consistent with the Supreme Court's definition of "search" and "seizure" for Fourth Amendment purposes. ${ }^{276}$ Then, as in the earlier study, ${ }^{277}$ the subjects were told to rate each scenario in terms of "intrusiveness" on a scale of 1 to 100 , with 1 representing "not intrusive" and 100 representing "very intrusive."

Using these ratings, an average intrusiveness rating for each scenario was calculated, along with the standard deviation so that the statistical significance of any differences between averages could be computed. As with the previous study, several such differences resulted. Table 1 reports the mean intrusiveness rating of the twenty scenarios, ${ }^{278}$ together with their

\footnotetext{
275 See supra note 47 and accompanying text

274 The survey forms are on file with the author and the Mississippi Law

273 Slobogin \& Shumacher, supra note 270, at 736.

${ }^{276}$ See, e.g., Florida v. Bostick, 501 U.S. 429, 438 (1991)("the 'reasonable
} Journal. person' test presupposes an innocent person"); Florida v. Royer, 460 U.S. 491,519 n.4 (1983)(Blackmun, J., dissenting) ("The fact that [respondent] knew the search was likely to turn up contraband is of course irrelevant; the potential intrusiveness of the officers' conduct must be judged from the viewpoint of an innocent person in [his] position").

277 Slobogin \& Schumacher, supra note 270 , at 736.

278 Some of the scenarios in this study that were very similar to those used in the previous one received significantly different means. For example, the coal mine inspection scenario yielded a mean of 25 in this study versus a mean of 52 in the previous one; the patdown scenario a mean of 68 in this study and of 55 in the previous one; the border body cavity search scenario a mean of 75 in this study and of 90 in the previous one. Comparisons are problematic, however, because the previous study incorporated many variations that were not present in this study. See id. at 733-36. Also, the patdown scenario in the present study 
confidence intervals (a figure which, when added to or subtracted from the mean, indicates the extent to which a given difference between means is statistically significant ${ }^{279}$ ). The following discussion will focus on those findings most relevant to understanding what the subjects thought about camera surveillance.

TABLE 1

Mean Intrusiveness Ratings of Twenty Scenarios

Scenario

Mean Confidence

Interval

1. Looking in foliage in park

2. Heath \& safety inspection of factory

3. Monitoring cameras at national monuments

4. Monitoring cameras at government buildings, airports, train stations

5. Inspection of a coal mine

6. Monitoring cameras at convenience and retail stores

7. Stopping drivers at roadblock for $\mathbf{1 5}$ seconds

8. Monitoring covert street cameras with zoom capacity

9. Flying helicopter 400 feet over backyard

10. Police officer noticeably following person down street

11. Going through garbage cans at curbside

12. Search of a junkyard

13. Monitoring overt street cameras; tapes destroyed after 96 hours

14. Monitoring a beeper on a car for three days

15. Use of device that can see through clothing to detect outline of items

16. A patdown of outer clothing, feeling for weapons

17. Use of a video camera to overhear a conversation on the street

18. Same as 13, but tapes not destroyed

19. Body cavity search at border

20. Search of bedroom

$\begin{array}{ll}8 & \pm 4 \\ 14 & \pm 4 \\ 20 & \pm 7 \\ 20 & \pm 7 \\ 25 & \pm 5 \\ & \\ 26 & \pm 8 \\ 35 & \pm 5 \\ & \\ 42 & \pm 9 \\ 50 & \pm 5 \\ & \\ 50 & \pm 5 \\ 51 & \pm 5 \\ 51 & \pm 5 \\ & \\ 53 & \pm 8 \\ 63 & \pm 5 \\ 67 & \\ 65 & \pm 5 \\ 68 & \pm 5 \\ 70 & \\ 75 & \\ 73 & \pm 8 \\ 75 & \pm 5 \\ 76 & \pm 5\end{array}$

stated that the officer "was feeling for weapons," whereas the previous study merely stated he patted down the outer clothing. Nonetheless, with the exception of the first two examples given, the hierarchy produced by the two studies is very similar.

${ }^{279}$ For explication, see id. at 745 n.67. The confidence intervals are larger for the camera surveillance scenarios because, given the desire to test variations of those scenarios, there were fewer surveys completed for each. 
The most important finding of the study for purposes of this article was the relative rating of the scenario involving cameras overtly positioned at 300-yard intervals along the street. As can be seen from Table 1, that scenario (\#13) received an average intrusiveness rating of $53(M=53)$. This rating was significantly lower (as a statistical matter) than the ratings for bedroom searches $(M=76)$, body cavity searches $(M=75)$ and electronic eavesdropping on conversations in public $(M=70)$, which require probable cause ${ }^{280}$ and also significantly lower than the rating for either a traditional $(M=68)$ or electronic frisk $(M=67)$, which require reasonable suspicion. ${ }^{281}$ At the same time, it was significantly higher than the average intrusiveness ratings for a health and safety inspection of a factory ( $M=14)$, an inspection of a coal mine $(M=25)$, and a 15second stop at a roadblock $(M=35)$, all government actions that the Supreme Court has declared are governed by the Fourth Amendment. ${ }^{282}$

${ }^{280}$ Searches of bedrooms and eavesdropping on "private" conversations carried out in public clearly require probable cause. Chimel v. California, 395 U.S. 752, 768 (1969)(holding non-exigent search of bedroom requires warrant); Katz v. United States, 389 U.S. 347, 361 (1967) (holding warrantless bugging of phone booth conversation unconstitutional because even though "booth is 'accessible to the public' at other times, . . . it is a temporarily private place whose momentary occupants' expectations of freedom from intrusion are recognized as reasonable."). Although the Supreme Court has avoided addressing the Fourth Amendment implications of body cavity searches, U.S. v. Montoya-Hernandez, 473 U.S. 531, 541 n.3 (1985), other courts have long required probable cause for such searches even when conducted at the border. See, e.g., Blackford v. U.S., 247 F.2d 745, 753 (9th Cir. 1957)(body cavity search at border permissible upon probable cause-" precise knowledge of what, and how much was where"-if conducted reasonably).

${ }^{281}$ Terry v. Ohio, 392 U.S. 1, 27 (1968)(holding patdown requires reasonable suspicion). The legality of electronic frisks has yet to be taken up directly, but because they reveal items underneath one's clothing, they presumably would require at least reasonable suspicion. See ABA STANDARDS, supra note 16, at 82-96 (discussing standards regulating "detection devices").

280 Donovan v. Dewey, 452 U.S. 594, 603 (1981)(requiring that inspection programs for coal mines provide "a constitutionally adequate substitute for a warrant); Marshall v. Barlow's, Inc. 436 U.S. 307, 324 (1978)(requiring administrative warrant for nonconsensual factory inspections); Martinez-Fuerte, 428 U.S. 543, 556 (1976)('It is agreed that checkpoint stops are 'seizures' within the meaning of the Fourth Amendment."). Note also that the public camera surveillance rating was similar to the rating received for the scenario involving the junkyard search, which is also governed by the Fourth Amendment. New York v. Burger, 482 U.S. 
The intrusiveness ratings for the other scenarios involving cameras fell within the range demarcated by the latter three scenarios, with one exception. While camera surveillance of national monuments $(M=20)$, transportation centers $(M=20)$ and stores $(M=26)$ received relatively low intrusiveness ratings, covert camera surveillance of the public streets $(M=42)$ received a significantly higher rating. At the same time, that rating is significantly lower than the rating for overt camera surveillance. Apparently, as suggested throughout this article, knowledge that cameras are present triggers a greater feeling of intrusion than knowledge that cameras might be present.

Also of note are the intrusiveness ratings of three government actions the Court has declared are not searches: helicopter overflights 400 feet above the backyard $(M=50)$, being followed by a police officer $(M=50)$, and curbside searches of garbage $(M=51){ }^{283}$ These three scenarios were perceived to be as intrusive, statistically speaking, as public camera surveillance, and significantly more intrusive than the administrative inspections and the roadblock.

Should these three findings call into question the Court's determinations that administrative inspections and roadblocks are Fourth Amendment events, or instead lead us to question the holdings that helicopter overflights, garbage scavenging and police tailing (and, by implication, public camera surveillance) are not? Consistent with the thesis of this article, I believe we should be more concerned about the second conclusion. While, as noted earlier, ${ }^{284}$ the Court seems to place all police actions that are not physically invasive and that occur outside the home outside the Fourth Amendment as well, the subjects were apparently more attuned to the offensive nature of government helicopters hovering over one's yard, agents going through one's intimate, albeit abandoned, items, and officers stalking citizens. At the same time, the lower ratings the sur-

691 (1987)(applying Dewey to inspections of junkyards for stolen auto parts).

${ }^{283}$ Florida v. Riley, 488 U.S. 445 (1989)(helicopter 400 feet above backyard);

Michigan v. Chesternut, 486 U.S. 567 (1988); California v. Greenwood, 486 U.S.

35 (1988)(searching garbage separated from other garbage).

284 See supra text accompanying notes 243-47. 
vey participants assigned to business safety inspections and brief car detentions are not inconsistent with the view that the Fourth Amendment is implicated by these actions, as they are still significantly higher than searching through foliage in a public $(M=8)$. Put simply, the participants are better than the Court at identifying expectations of privacy society is prepared to recognize as reasonable.

\section{The Relevance of Empirical Findings}

As Professor Schumacher and I noted in connection with the previous study, there are several potential methodological problems with this kind of survey. ${ }^{285}$ These "internal validity" and sampling issues will not be rehearsed here. It suffices to say that, despite some reservations, we concluded in the earlier work that this type of survey "accurately measured how people rank the intrusiveness of various search and seizures." 286

Assuming the same conclusion can be reached about the present study, it is still important to revisit one central issue: Why should we care, for constitutional purposes, what ordinary people think about the intrusiveness of various police actions? One easy answer is the one already given: the Court has told us society's views are relevant by defining the Fourth Amendment in terms of "expectations of privacy society is prepared to recognize as reasonable." 287

But perhaps this language should not be interpreted literally. There are a number of reasons why it may be a bad idea to do so. These reasons are all complicated, and will only be briefly described here. I will respond to these objections in an equally brief, and I have to admit, incomplete fashion.

One reason to avoid a literal reading of Katz is the variability and manipulability of public attitudes. As many commentators have pointed out, ${ }^{288}$ technology and modern social

${ }^{238}$ Slobogin \& Schumacher, supra note 270, at 743-51.

288 Slobogin \& Schumacher, supra note 270 , at 744.

287 Katz v. United States, 389 U.S. 347, 361 (1967)(Harlan, J., concurring).

${ }^{285}$ See, e.g, Sundby, supra note 255 , at 23 (stating the "overall decline in the Amendment's protections . . . will only worsen as the inevitable march of government regulation further blurs the notion of what is private and as technological advances enable the government to invade privacy in more pervasive, but physi- 
practices are rapidly reducing everyone's privacy and everyone's expectations thereof, with the result that a literal construction of Katz would produce an ever-shrinking Fourth Amendment. Resort to empirical data about society's attitudes in defining the Fourth Amendment's scope would probably only accelerate that trend, and destabilize search and seizure law at the same time.

Research such as that described here, however, only provides information about relative intrusiveness in society's eyes. It does not tell the Court where to position the Fourth Amendment threshold. The decision as to what level of privacy expectations is accorded constitutional protection can still be a judicial, normative one that has precedential impact. Nor are society's views likely to change once the Court sets the Fourth Amendment threshold, because the Court's pronouncement will reinforce those views. If, however, those views nonetheless change substantially-for instance, if twenty years from now, government-run CCTV is seen as much less intrusive than searching foliage in a public park, or much more intrusive than a frisk-then Fourth Amendment analysis should probably change with them. After all, that is what happened when Katz declared that non-trespassory electronic surveillance is a search after forty years of precedent saying otherwise. ${ }^{289}$

cally less intrusive, ways."); Shaun B. Spencer, Reasonable Expectations and the Erosion of Privacy, 39 SAN. DIEGO L. REV. 843 (2002)(pointing out that the "embedded imprecision" of the privacy concept and the incremental "internalization" of new privacy norms dictated by technological and other innovations operate together to erode privacy boundaries); Duarte v. R., 1 S.C.R. 30, para 24 (1990)("The very efficacy of electronic surveillance is such that it has the potential, if left unregulated, to annihilate any expectation that our communications will remain private.").

${ }^{280}$ Monahan and Walker argue that methodologically sound research that is relevant to a given legal issue should not only be considered by the courts, but should operate as "social authority," just as caselaw and statutes are considered legal authority. John Monahan \& Laurens Walker, Social Authority: Obtaining, Evaluating, and Establishing Social Science in Law, 134 U. PA. L. REv. 477, 488 (1986). On that assumption, if the relevant social science changes, the law based on it should change as well.

Like legal precedent, research findings can become outdated as circumstances change. A survey of the kinds of films that members of a community found "patently offensive" in the 1950's, for example, might have 
A second objection to a literal interpretation of Katz's expectation of privacy language is that, at the margins, it might render nugatory the language and history of the Fourth Amendment. Consider CCTV as an example. One could argue, as suggested earlier, ${ }^{290}$ that regardless of its relative intrusiveness according to the community, CCTV does not constitute either a "search" or a "seizure" of "persons, papers, houses and effects" as those terms are normally understood. One could also plausibly contend that it is not the type of government activity that even remotely concerned the framers. Yet, as developed further in Part IV, ${ }^{291}$ close scrutiny of a person, whether in public or private, can easily be called a "search." And while it is true that physical searches, particularly of homes, were the main concern of the framers, surveillance of the streets by British soldiers was a major irritant for the colonists. ${ }^{292}$ Ulti-

little value in the context of an obscenity prosecution in the 1980 's. A third way, therefore, that courts could evaluate a piece of social science research would be to gauge the extent to which the people and situations studied in the research resemble those involved in the controversy at issue, and the extent to which the passage of time may have attenuated the findings.

Id. at 507 (footnote omitted).

${ }_{200}$ See supra text accompanying notes 239-253.

${ }^{291}$ See infra text accompanying notes 421-422.

292 Anonymous Account of the Boston Massacre, at http://odur.let.rug.nl/usa/D/ 1751-1775boston-/anon.htm (stating that "the challenging of the inhabitants by sentinels posted in all parts of town . . . occasioned many quarrels and uneasiness"); see also Westin, supra note 115 , at 57-58 (noting that "[t]he whole network of American constitutional rights ... was established to curtail the ancient surveillance claims of governmental authorities."); Don B. Kates, The Second Amendment and the Ideology of Self-Protection, 9 CONST. COMMENTARY 87, 103 (1992)(stating that, for the Founders, "the very idea of empowering government to place an armed force in constant watch over the populace was vehemently rejected as a paradigm of abhorrent French despotism," and noting that organized police forces were resisted in colonial times). In correspondence with the author, Professor Davies, who has closely studied the Fourth Amendment's history, emphasized the last fact, noting that, other than "snooping" by British informers (which occasioned hostility among the colonists), there was no one available to conduct surveillance: "the constable had better things to do (trying to make a living) than stand around looking for hints of crime." E-mail from Thomas Davies, Professor of Law, University of Tennessee School of Law, to Christopher Slobogin, Professor of Law, the University of Florida School of Law (July 8, 2002, 2:16 PM CST)(on file with author). Davies also noted the lack of surveillance technology in colonial times and pointed out that "surveillers would have had more difficulty 
mately, however, the strength of this second objection depends upon how important "plain meaning" and original intent are to Fourth Amendment analysis and upon what these phrases mean, topics well beyond the scope of this article. ${ }^{293}$

A related and final objection to taking $\mathrm{Katz}$ literally is that courts should consider only these latter types of factors because courts are, by tradition if not by definition, nonmajoritarian institutions. While some constitutional issues-the definition of obscenity comes to mind ${ }^{294}$-are largely determined by community views, most such issues-compulsion for Fifth Amendment purposes, ${ }^{295}$ speech under the First Amendment, ${ }^{296}$ probable cause for Fourth Amendment purposes ${ }^{297}$-are not. ${ }^{298}$ At the least, shouldn't the courts ignore community norms that are inconsistent with principles derived from other sources when determining the scope of core constitutional concepts?

This question is also huge and difficult, and the answer depends much upon context. ${ }^{299}$ A recent article by Robert

blending into the smaller, closer social settings of that time." Id.

${ }_{220}$ See generally David Sklansky, The Fourth Amendment and the Common Law, 100 COLUM. L. REV. 1734 (2000):

[A]nchoring the Fourth Amendment in common law will do little to make it more principled or predictable, in part because common-law limits on searches and seizures were thinner, vaguer, and far more varied than the Court seems to suppose. What the common law has of value to offer Fourth Amendment law is what it has to offer constitutional law more generally: not its rules but its method.").

Id. at 1734 .

24 Miller v. California, 413 U.S. 15, 24 (1973)(whether a work appeals to the "prurient interest" is to be defined by "community standards"); see also Atkins v. Virginia, 122 S.Ct. 2242, 2244 (2002)(ruling that the definition of cruel and unusual punishment under Eighth Amendment is dependent upon consensus of public, judges, legislators and scholars).

${ }_{286}$ See, e.g., Miranda v. Arizona, 384 U.S. 436 (1966).

${ }_{296}$ See, e.g., Tinker v. Des Moines Indep. Cmty. Sch. Dist., 393 U.S. 503 (1969).

29n See, e.g., Illinois v. Gates, 462 U.S. 213 (1983).

290 Cf. West Virginia State Bd. of Educ. v. Barnette, 319 U.S. 624, 638 (1943)('One's right to life, liberty, and property, to free speech, a free press, freedom of worship and assembly, and other fundamental rights may not be submitted to vote; they depend on the outcome of no elections.").

239 I have argued, for instance, that public opinion is of very limited relevance in designing provisions of the substantive criminal law. Christopher Slobogin, Is Justice Just Us? Using Social Science to Inform Substantive Criminal Law, $87 \mathrm{~J}$. 
Post, a noted scholar on privacy issues, provides the beginning of a response, a response pertinent to the other two objections as well. Post describes three possible "concepts of privacy": privacy as the control of knowledge; privacy as a protector of dignity; and privacy as a means of implementing freedom. ${ }^{300}$ The first concept, he argues, does not really raise a privacy question at all, because it has more to do with disclosure of information rather than with intrusion, and the third he sees as "an argument for liberal limitations on government" such as those imposed by cases like Roe $v$. Wade. ${ }^{301}$ The form of privacy he views as most relevant to Fourth Amendment issues is privacy as dignity, which grounds privacy "in social forms of respect that we owe each other as members of a common community,,$^{n 02}$ and "locates privacy in precisely the aspects of social life that are shared and mutual. ${ }^{303} \mathrm{He}$ asserts that, when privacy "is understood as a form of dignity, there can ultimately be no other measure of privacy than the social norms that actually exist in our civilization. ${ }^{\text {"304 }}$ If that is so, then Fourth Amendment privacy depends upon measurements of societal norms regarding privacy expectations, which is what the surveys described above attempt to measure.

There is also an institutional reason to align Fourth Amendment expectations of privacy with society's views on the matter. As stated in the article describing the first study, "[a]ssuming valid data showing that the community and the Court think differently, the Court's continued adherence to its own views, through what has aptly been called normative constitutional fact-finding, would further strain its credibility. ${ }^{\$ 305}$ Ultimately, ignoring such data and the community views it

Crim. L. \& Criminology. 315 (1996).

300 Robert C. Post, Three Concepts of Privacy, 89 GEo. L.J. 2087 (2001).

${ }^{301}$ Id. at 2087, 2087-92, 2096-98.

200 Id. at 2092.

200 Id. at 2094 .

304 Id.

${ }^{306}$ Slobogin \& Schumacher, supra note 270, at 753 (footnote omitted)(relying on David L. Faigman, "Normative Constitutional Fact-finding": Exploring the Empirical Component of Constitutional Interpretation, 139 U. PA. L. REV. 541, 581-88 (1991)). 
represents "undermines the Court's legitimacy."

\section{Summary}

A good case can be made for the conclusion that overt CCTV operated by the government in public spaces ought to be subject to constitutional regulation. The source of such regulation could be the First Amendment, the right to travel found in the Due Process Clause, the general right to privacy, or the Fourth Amendment. CCTV can intimidate those engaging in political expression, inhibit public movement and repose, affect one's public personality, accelerate normalization and, if the empirical study reported here is any indication, be as intrusive as police actions which the Supreme Court has said implicate the Fourth Amendment. Although the interests infringed by CCTV are somewhat disparate, they can all be subsumed under the umbrella interest in public anonymity-the right to be free of intensive government scrutiny even in public, absent suspicious conduct. ${ }^{307}$

Of the various constitutional bases that could implement this right to anonymity, I prefer the Fourth Amendment, for two related reasons. First, it is the amendment that traditionally has been applied to police investigation techniques, and CCTV is such a technique. The Court has suggested that when two or more constitutional provisions are implicated, the one most directly implicated should apply. ${ }^{308}$ Second, Fourth Amendment analysis provides a better framework for regulating CCTV than the other constitutional doctrines. If a govern-

300 Id.

${ }^{307}$ Note, however, one difference between a right to anonymity and the other rights. Each of the other rights could be said to be inhibited by crime at least as much as by cameras (consider in particular the right to movement and repose). Thus, one could argue they are infringed if government does not install CCTV, at least in high crime areas. See infra Part IIIA. The right to anonymity is more clearly independent of the fear of crime; it is always implicated by CCTV.

s06 Albright v. Oliver, 5120 U.S. 266, 273 (1994)(“[W]here a particular amendment provides an explicit textual source of constitutional protection' against a particular sort of government behavior, that Amendment, not the more generalized notion of 'substantive due process,' must be the guide for analyzing these claims"' (quoting Graham v. Connor, 490 U.S. 386, 395 (1989)). 
ment action infringes the First Amendment, the Due Process Clause, or the general right to privacy, its permissibility depends upon whether the government has a "compelling" or "substantial" interest in pursuing the action, concepts that are very ill-defined. ${ }^{309}$ Depending upon the interest involved, the action's legitimacy may also depend on how "necessary" it is to accomplish that interest, again a nebulously defined inquiry. ${ }^{310}$ Although essentially the same analysis occurs under the Fourth Amendment, its greater flexibility and its better-developed substantive and procedural rules provide a more concrete regulatory template, as Part III demonstrates.

\section{IMPLEMENTING THE RIGHT TO PUBLIC ANONYMITY}

I propose that constitutional regulation of government efforts to pierce public anonymity through CCTV consist of four components. First, law enforcement should have to justify both the establishment of a particular camera system and its use to scrutinize particular individuals. Second, it should have to develop policies regarding the procedure for conducting camera surveillance. Third, it should have to develop policies regarding storage and dissemination of recorded materials to other entities. Finally, and most importantly, it should be accountable to entities outside law enforcement when it fails to follow these three requirements.

Even this barebones description of the regulatory scheme sounds decidedly legislative in nature, and therefore arguably something the judiciary is not equipped to fashion. But, as the following discussion will make clear, the judicial objective should be merely to establish the regulatory framework; law enforcement agencies and the political process can fill in the details. Erik Luna has described the phenomenon of "constitutional roadmapping," in which the courts, in striking down governmental laws or censoring conduct of government agents, suggest constitutionally permissible alternative courses of action. ${ }^{311}$ The idea behind such decisions is to engage in a dia-

\footnotetext{
${ }^{309}$ See generally CHEMERINSKY, supra note 214, at 764-768

310 Id.

s11 Erik Luna, Constitutional Roadmaps, 90 J. CRIM. L. \& CRIMmNology. 1125,
} 
logue with other decision-makers in the executive and legislative branches, as well as with the citizenry. ${ }^{312}$ As Luna says, "[r]oadmaps openly share constitutional concerns with those institutions charged with making and enforcing law, refracting issues with judicial insight rather than merely reflecting them back to the political branches. ${ }^{n 313}$ Although Luna believes that judicial resort to such roadmaps should be rare, he also states that they are most likely to be useful in individual rights cases involving new practices where the need for clear rules is high, a scenario which resonates with the advent of CCTV. ${ }^{314}$ The discussion below tries to set out a constitutional roadmap for public camera surveillance, relying on Fourth Amendment precedent for guiding principles and the ABA's Standards Relating to Technologically-Assisted Physical Surveillance for slightly more specific recommendations. ${ }^{315}$

\section{A. Justification}

The government should be required to justify its use of cameras at two different levels. First, it should have to justify the placement of the cameras it seeks to install. Second, it should have to account for any use of the camera to individualize its inspection of particular individuals. Precedent for requiring both types of justifications comes from the Supreme Court's cases on roadblocks, which, it will be remembered, were viewed by the subjects in the study reported above to be significantly less intrusive than CCTV.

\section{Justifying Camera Location}

One might think that the cost of camera systems, alone, would keep CCTV from spreading beyond those areas with the

\footnotetext{
1193 (2000).

s12 Id. at 1185-87.

s1s Id. at 1193 .

s14 Id. at 1200-06.

315 See generally Christopher Slobogin, Technologically-Assisted Physical Surveillance: The American Bar Association's Tentative Draft Standards, 10 HARV. J. L. \& TECHNOLOGY 383 (1997)(describing the membership and work of the Task Force and the Standards Committee in developing the Standards).
} 
highest crime rates. But, if Great Britain's experience is any indication, cameras are likely to be seen as a cheap, effective method of deterring and detecting crime, whether or not that is actually the case. ${ }^{316}$ Thus, their proliferation beyond the most dangerous areas is inevitable, unless limitations are imposed.

The precedent for that limitation comes from an unlikely source, the Supreme Court's roadblock jurisprudence. ${ }^{317}$ In the four cases in which the court has pronounced on the constitutionality of roadblocks, the government has prevailed three times. In United States v. Martinez-Fuerte, ${ }^{318}$ the Court upheld checkpoints established near the Mexican border that were designed to deter and detect illegal immigration. In Michigan v. Sitz, ${ }^{319}$ it sanctioned roadblocks to deter drunken driving. And in Delaware v. Prouse, ${ }^{320}$ it indicated in dictum that license checkpoints would be constitutional as well (in the course of holding that random license checks of individual cars are unconstitutional). ${ }^{321}$

In a case decided just last term, however, the Court drew the line at roadblocks that are set up merely to help the government catch more criminals. In Edmond $v$. Indianapolis, ${ }^{322}$

516 See supra note 94; see also Davies, supra note 38, at 150 (observing that every year between 230 and 450 million dollars is spent on CCTV in the United Kingdom, despite its uncertain effectiveness).

317 Note that, given the intrusiveness ratings of the coal mine and factory inspection scenarios, see supra p. 277 Table 1, another source of precedent would be the closely regulated industry cases. See CHARLES H. WHITEBREAD \& CHRISTOpher Slobogin, Criminal Procedure: an analysis of Cases \& Concepts $\$ 13.03$ (a) (4th ed. 2000)(describing the cases). But these decisions deal with specific industries, not the public at large, so roadblocks provide a closer analogue to CCTV. It is worth noting, however, that the pervasively regulated industry cases require the government to show a "substantial" interest in the activity being regulated, and also require limitations on when and how searches can be carried out that provide "a constitutionally adequate substitute for a warrant." Dewey v. Donovan, 452 U.S. 594, 602-03 (1981).

s18 428 U.S. 543, 566-67 (1976).

319496 U.S. 444,455 (1990).

320440 U.S. 648, 657 (1979).

${ }^{321}$ Prouse, 440 U.S. at 663 ("This holding does not preclude the State of Delaware or other States from developing methods for spot checks that involve less intrusion or that do not involve the unconstrained exercise of discretion. Questioning of all oncoming traffic at roadblock-type stops is one possible alternative.").

${ }^{322} 531$ U.S. 32 (2000). 
in an opinion by Justice O'Connor, the Court held unconstitutional a "narcotics checkpoint," stating "[w]e have never approved a checkpoint program whose primary purpose was to detect evidence of ordinary criminal wrongdoing. ${ }^{\text {"323 }}$ MartinezFuerte, O'Connor stated, was grounded on the "formidable law enforcement problems" connected with "effectively containing illegal immigration at the border," the "impracticality of the particularized study of a given car to discern whether it was transporting illegal aliens," and the traditional leeway given the government's efforts at protecting the "integrity of the border. ${ }^{324}$ The sobriety checkpoints in Sitz were permissible because they were aimed at reducing "the immediate vehiclebound threat to life and limb" posed by the presence of drunk drivers on the highways. ${ }^{325}$ And license checkpoints of the type discussed in Prouse, O'Connor stated, are meant to maintain highway safety through ensuring that drivers are qualified and that their vehicles are fit for safe operation. ${ }^{326}$ None of these roadblock variants, the Edmond majority emphasized, are established to further the government's "general interest in crime control." ${ }^{327}$ In the latter situation, an "individualized suspicion" requirement prevails. ${ }^{328}$ Otherwise, "the Fourth Amendment would do little to prevent such intrusions from becoming a routine part of American life. ${ }^{\text {s29 }}$

There is no doubt that the "primary purpose" of CCTV is to implement the government's general interest in crime control. If we assume, as concluded above, that CCTV is regulated by the Fourth Amendment, Edmond could be read to prohibit government use of cameras, unless it first develops individualized suspicion. That would effectively eliminate CCTV as a

325 Edmond, 531 U.S. at 41.

s24 Id. at 38 .

325 Id. at 43 .

326 Id. at 39 .

s27 Id. at $43-44$.

328 Id. at 44 .

${ }^{329}$ Id. at 42. The same Term the Court struck down a drug-testing policy aimed at pregnant women, in large part because the "primary purpose" of the program was "the threat of arrest and prosecution in order to force women into treatment." Ferguson v. City of Charleston, 532 U.S. 67, 84 (2001). 
deterrent and seriously limit its usefulness as an investigative device, except in those rare instances when individualized suspicion is developed in other ways and cameras are needed to provide corroboration or help nab a suspect who has eluded police.

More generously, Edmond could be interpreted to permit suspicionless public camera surveillance if the government meets the requirements imposed by Martinez-Fuerte or Sitz. In other words, only where it can be shown that there are "formidable law enforcement problems" associated with using traditional methods of investigation (as in the case of discerning illegal immigrants in cars) or an "immediate hazard to life and limb" posed by a specified group of potentially dangerous people (as with drunk drivers) should CCTV be permissible.

Where might such circumstances exist? Areas with a high magnitude of serious crime are the best candidates. A significant amount of crime suggests that traditional methods are not working, and if much of the crime being committed is violent or similarly serious, it presents an immediate hazard proportionate to that posed by drunk drivers.

Taking a cue from the Court's cases, it is possible to get even more specific about the degree of harm necessary to justify brief suspicionless surveillance. In Sitz the Court gave as one of the reasons the checkpoint in that case was reasonable the fact that $1.6 \%$ of the drivers who went through the roadblock in that case were drunk, and also noted that $.12 \%$ of those stopped at the checkpoint in Martinez-Fuerte were illegal immigrants. ${ }^{300}$ The latter percentage might presumptively be considered the threshold at which government can act, for two reasons. First, it justified only the barest of seizures, one that lasted at most five seconds and that often consisted merely of getting the vehicle to slow down so that border agents could look inside. ${ }^{331}$ Anything less intrusive would probably not have implicated the Fourth Amendment at all; anything more

s30 Sitz, 496 U.S. at 455.

ssi Martinez-Fuerte, 428 U.S. at 546 ('The point' agent standing between the two lanes of traffic visually screens all northbound vehicles, which the checkpoint brings to a virtual, if not a complete, halt. Most motorists are allowed to resume their progress without any oral inquiry or close visual examination."). 
should require at least as much justification as the government proffered in Martinez-Fuerte. Second, the Court has indicated it is leery of suspicionless seizures that inconvenience large numbers of individuals for very little gain. In finding unconstitutional the random license checks at issue in Prouse, it noted that "[i]t seems common sense that the percentage of all drivers on the road who are driving without a license is very small and that the number of licensed drivers who will be stopped in order to find one unlicensed operator will be large indeed. ${ }^{n 332}$ Although Prouse went on to sanction nonrandom roadblocks for license check purposes, ${ }^{333}$ this type of seizure, Edmond held, is permitted only when it is directly related to highway safety, and not set up with the primary purpose of crime control. In the latter instance, Prouse and Edmond in combination would seem to say that hit rates lower than those obtained in Martinez-Fuerte cannot justify searches or seizures by the government.

In somewhat arbitrary terms, then, CCTV might only be permitted in areas where more than one person in 1000 will commit violent or similarly serious crime. ${ }^{334}$ It might also be permissible in more idiosyncratic circumstances. For instance, cameras could perhaps be positioned in areas that are not particularly dangerous, but are predicted to be because of some imminent threat to life and limb, such as terrorism. ${ }^{335}$ Study

932 Prouse, 440 U.S. at 659-60.

s3s Id. at 663 .

ss4 It might be noted that the "hit rate" for the checkpoint declared unconstitutional in Edmond was much higher. Edmond, 531 U.S. at 35 (9\% of those who were stopped at roadblock were guilty of some crime). But it appears that the crimes detected by the Edmond checkpoint were primarily low-level drug violations, not violent offenses. Id.

sss See id. at 44 ("the Fourth Amendment would almost certainly permit an appropriately tailored roadblock set up to thwart an imminent terrorist attack or to catch a dangerous criminal who is likely to flee by way of a particular route"). Cameras might also be set up in certain areas, but switched off except during particular times or events. See Testimony of Charles H. Ramsey, Chief of Police, D.C. Metropolitan Police Department, at Hearing on Privacy vs. Security: Electronic Surveillance in the Nation's Capital, before House Comm. on Gov't Reform, Subcomm. on Dist. Colum., March 22, 2002, at 3 (on file with author):

Access to outside systems is controlled by the agency that operates the cameras, not the Metropolitan Police Department. The only way the MPD 
of crime patterns might also identify some locales that are particularly likely to attract certain types of serious criminal activity or harbor dangerous criminals. ${ }^{336}$

A corollary question is: Who decides whether crime in a given area is of sufficient magnitude to warrant CCTV-a court, a legislature, the police or the public? In rejecting a judicial determination of a roadblock's "effectiveness" at dealing with drunk driving, the Court in Sitz stated it would not "transfer from politically accountable officials to the courts the decision as to which among reasonable alternative law enforcement techniques should be employed to deal with a serious public danger. ${ }^{\text {n37 }}$ It went on to conclude that, "for purposes of Fourth Amendment analysis, the choice among such reasonable alternatives remains with the governmental officials who have a unique understanding of, and a responsibility for, limited public resources, including a finite number of police officers. $"$ "338

While this language appears to leave quite a bit up to police discretion, it also endorses two significant limitations on that discretion. First, courts are not left out of the picture entirely. They are still permitted to intervene when the alternative chosen by the police is not "reasonable." Second, decisionmaking authority is not delegated to any or every officer, but rather only to "politically accountable" officials who have "responsibility for limited public resources." In other words, the chief of the department ought to be responsible for these decisions. That conclusion makes sense, given that official's better access to the relevant statistics and the number of people affected by the decision. ${ }^{339}$

will be able to access the [schools'] video system is if school officials ask us to do so, and then provide the 'key' to grant us access.

ss6 Cf. Erik Luna, Transparent Policing, 85 IowA L. REv. 1107, 1173 (2000) ("Criminologists have offered geographic theories of target hunting, fugitive migration, crime trips, escape routes, and repeat location victimization, as well as theories of aggregate behavior based on market distribution, crime displacement, and police-crackdown effects.").

397 Sitz, 496 U.S. at 453.

${ }^{938}$ Id. at 453-54.

s39 The commentary to the ABA Standards sets out in more detail reasons to 
This last observation also raises the issue of whether the public should be involved in the decisionmaking to any extent. The Court has not specifically addressed this question. But William Stuntz has argued that Sitz stands for the proposition that the public should be directly involved in such cases. ${ }^{340}$ More specifically, he posits that Sitz indicates the Court's willingness to abandon both the individualized suspicion and special needs models of the Fourth Amendment in favor of what he calls a "politics model" when searches or seizures affect large groups of people, because a group, unlike the solitary suspect who is usually the target of searches and seizures, can "throw the rascals out" if it does not like a particular technique. ${ }^{341}$

If Stuntz is right about the Court's underlying motivation in Sitz, the practical problem becomes how to implement this "politics model." The typical electoral process, which is likely to involve many issues, is not an effective way for the group to make its attitudes toward a particular police action known. A more satisfactory implementation of the model would be to require direct input on the establishment of camera systems from those who will enjoy the benefit and bear the brunt of the surveillance. Such input can also provide the police with information about specific crime problems and the type of surveillance that might prove most useful. ${ }^{342}$ It is instructive that

involve politically accountable decisionmakers:

First, these decisionmakers are more representative of the public than is a supervisor or field officer. In addition a decision which is likely to affect large numbers of people for a long period of time should not be made by a low-level official, regardless of the latter's expertise and knowledge of local conditions. Finally, only at the departmental level are the relevant statistics necessary for documenting a crime problem likely to be available.

ABA STANDARDS, supra note 16 , at 69 .

s40 William J. Stuntz, Implicit Bargains, Government Power, and the Fourth Amendment, 44 Stan. L. Rev. 553 (1992).

s41 Id. at 588 .

30 One question raised by this comment is whether the public can "force" the installation of cameras when it is not warranted under the foregoing analysis. Professors Meares and Kahan argue that when "the community has internalized the burden that a particular law imposes on individual freedom" courts "should presume that the law does not violate individual rights." Tracey L. Meares \& 
several participants at the International Association of Police Chiefs meeting on CCTV were adamant about involving the affected community in decisions involving cameras. ${ }^{343}$

The American Bar Association's Standards on Technologically-Assisted Physical Surveillance address all of these concerns about the decision to establish cameras. They state that CCTV "is permissible when a politically accountable governmental authority concludes that the surveillance will not view a private activity or condition and will be reasonably likely to achieve a legitimate law enforcement objective. ${ }^{\text {344 }}$ The latter phrase is defined to require "articulable reasons" for concluding that the surveillance will lead to the detection, deterrence or prevention of crime ${ }^{345}$ which, after Edmond, should require a demonstration that a significant violent crime problem will be addressed by the surveillance. The Standards also require that "where deterrence rather than investigation is the primary object, the public to be affected by the surveillance... . [should have] the opportunity, both prior to the initiation of the surveillance and periodically during it, to express its views of the surveillance and propose changes in its execution, through a hearing or some other appropriate means." ${ }^{346}$ These are the kinds of general guidelines the courts can fashion based on Fourth

Dan M. Kahan, The Wages of Antiquated Procedural Thinking: A Critique of Chicago v. Morales, $1998 \mathrm{U}$. Chi. Legal F. 197, 209. But the "community" is hard to gauge. Compare Remarks of Joseph Dunne, supra note 86, at 21 ("Virtually every housing development in New York City has requested a CCTV monitoring program") with Burrows, supra note 56, at 1082 (describing how cameras were installed when long-term, largely elderly residents became concerned about crime as black and hispanic individuals moved nearby). And while arguments can be made that community views are dispositive on the privacy issue, see supra text accompanying notes 286-306, it is clear that Fourth Amendment reasonableness is ultimately a judicial matter. Nonetheless, if a "well-informed" community (cf. supra note 144), clearly favors cameras, a (rebuttable) presumption in their favor may be a workable approach.

343 See, e.g., Remarks of Lessing Gold, supra note 99, at 19 (stating "we must form a coalition or partnership with law enforcement, city council, citizens groups and private sector"); Jerry Semper (Maryland Police Trainer), at SIA \& IACP Meeting, supra note 62, at 55 (stating "community inclusion is the most important aspect of what we've got going on here").

34t ABA STANDARDS, supra note 16, at 16 (Standard 2-9.3(b)(i)).

345 ABA STANDARDS, supra note 16, at 14-15 (Standard 2-9.2(d)).

s46 ABA STANDARDS, supra note 16, at 16 (Standard 2-9.3(b)(ii)). 
Amendment principles.

\section{Justifying Individualization of Surveillance}

If the Edmond standard is met for a particular area, then CCTV cameras can be established there consistent with the Fourth Amendment. Randomly panning the camera to scan the streets ought to be permissible on the same showing, just as the brief initial stops in Martinez-Fuerte and Sitz were permitted without any individualized suspicion. But what if the camera operators want to record or closely observe a particular person's actions, using zoom capacity, or simply through prolonged or repeated surveillance? For instance, the only comprehensive study of CCTV operator behavior found that in approximately 600 hours of observation almost 900 "targeted surveillances" of more than a minute occurred, with roughly three out of ten lasting between two minutes and six minutes, and one-quarter lasting longer than six minutes. ${ }^{947}$

Here again, the roadblock cases lead the way. In Sitz, the Court cautioned that it was addressing "only the initial stop of each motorist passing through a checkpoint and the associated preliminary questioning and observation by checkpoint officers. Detention of particular motorists for more extensive field sobriety testing may require satisfaction of an individualized suspicion standard." ${ }^{348}$ Similarly, in Martinez-Fuerte, the Court felt it important to note that the percentage of illegal immigrants discovered at the "secondary checkpoint" to which motorists were sent after the initial stop was close to $20 \%,{ }^{349}$ a figure that demonstrates a relatively high level of suspicion associated with this seizure, which amounted to a five-minute document check. ${ }^{350}$

These cases suggest that something more than an inchoate hunch ought to form the basis for intense scrutiny of individuals. Certainly use of audio capacity to eavesdrop on private conversations on the street ought to be based on individualized

\footnotetext{
37 NORRIS \& ARMSTRONG, supra note 44, at 150.

346 Sitz, 496 U.S. at 451.

39 Martinez-Fuerte, 428 at 564 n.17.

sso Id. at 547 .
} 
suspicion, presumably at the probable cause level. ${ }^{951}$ Likewise, if the camera is used to intrude into the interior of the home, probable cause should be required. ${ }^{352}$

Short of these two situations, determining precisely when surveillance progresses from random scanning or casual surveillance to observation intense enough to warrant individualized suspicion may be difficult. But it will not be any more difficult than defining when a nonseizure becomes a seizure, or determining when a stop requiring reasonable suspicion becomes an arrest requiring probable cause, issues with which the Supreme Court has grappled-not always satisfactorily-on several occasions. ${ }^{353}$ Two factors that ought to be relevant here, according to the ABA Standards, are "the extent to which the surveillance technology enhances the law enforcement officer's natural senses" and "the extent to which the surveillance of subjects is minimized in time and space. ${ }^{354}$ If the camera's zoom or recording capacity allows operators to obtain information that would be difficult for an observer on the street to discern (such as a title on a book cover, or a biometric match with official records), then reasonable suspicion ought to be required; the same standard ought to be met if the cameras intentionally follow an individual for a prolonged period of time (say, more than the five minutes involved at the secondary checkpoint in Martinez Fuerte) or on several separate occasions (analogous to Rehnquist's bar example). Even a targeted surveillance lasting only a minute should require an articulated reason beyond mere curiosity (such as a signal from one of the automated systems described earlier ${ }^{355}$ ). The amount of individualized scrutiny permitted should be roughly proportionate to the amount of individualized suspicion the government has developed.

These latter proposals may appear to contradict the Court's decision in Knotts, upholding suspicionless tracking of public

\footnotetext{
351 See supra notes $167 \& 280$.

333 See supra text accompanying notes 245-47.

sss See WHITEBREAD \& SLOBOGIN, supra note $317, \S 3.02$ (describing cases defining arrest) \& $\S 11.02$ (describing cases defining "seizure").

sst ABA STANDARDS, supra note 16, at 12 (Standards 2-9.1(c)(ii)(E) \& (F)).

sss See supra text accompanying notes 44-47.
} 
movements, using a beeper. ${ }^{356}$ But the beeper only indicates the location of an object or person; video surveillance provides government with much more. More importantly, unlike the beeper, CCTV is overt, and thus generates a much greater panoptic effect. In any event, the results of the study reported earlier indicate that using a beeper to monitor travel was rated as almost as intrusive as a frisk, ${ }^{357}$ suggesting that members of the public believe that prolonged tracking with a beeper is much more invasive than the Court seems to think.

\section{B. Execution Issues}

The traditional search or seizure must not only be justified, but must also be executed in a reasonable manner. Based on the Court's caselaw, three execution issues associated with CCTV might rise to the constitutional level. They concern notice of the surveillance, the types of individuals to be observed, and termination of the surveillance.

\section{Notice}

If the point of CCTV is deterrence, as its advocates claim, then notification of those subject to camera surveillance is imperative. ${ }^{358}$ Independently of this government interest, the Fourth Amendment also imposes a notice requirement. One of the primary reasons the Court gave in Martinez-Fuerte for finding the intrusion associated with the roadblocks in that case "minimal" was that, given the signs announcing their existence, motorists were "not taken by surprise;" further, because of this notification, they "know, or may obtain knowledge of, the location of the checkpoints and will not be stopped elsewhere. ${ }^{\text {359 }}$ The Court also stated that the intrusion was fur-

${ }^{366}$ See supra text accompanying notes 5-10.

257 The beeper scenario received a mean intrusiveness rating of 63 , while the frisk was rated at 68 . See Table 1, supra, p. 277.

${ }^{3 s 8}$ Zuckerman, supra note 32 (quoting Simon Davies as saying that, in the United Kingdom, "with 1.5 million cameras about, the signs would be a public nuisance. So there's a general acceptance that wherever you go, you will have cameras pointed at you.").

${ }^{359}$ Martinez-Fuerte, 428 U.S. at 559. 
ther minimized because the checkpoints appeared to be "duly authorized, ${ }^{\prime 360}$ another function signs can carry out.

Other Court decisions upholding suspicionless government actions have reaffirmed that notice is an important means of meeting Fourth Amendment requirements. For instance, in Von Raab $v$. United States, ${ }^{361}$ involving drug testing of people who applied and worked for the customs service, the Court emphasized that "[e]mployees are . . . notified in advance of the scheduled sample collection, thus reducing to a minimum any 'unsettling show of authority' [citing Prouse] that may be associated with unexpected intrusions on privacy. ${ }^{\text {362 }}$ In Wyman $v$. James, permitting suspicionless welfare inspections of the home, the Court reasoned that providing a welfare recipient with advance notice of the inspection minimized the intrusion on privacy occasioned by the visit. ${ }^{363}$ A number of Court cases also suggest that suspicionless searches are more palatable when the targets "consent" to them ahead of time, which is impossible without some sort of notice. ${ }^{364}$

\section{Avoiding Discriminatory Surveillance}

The second execution issue of possible constitutional significance is the selection of people to be observed by the cameras. Because no suspicion is required for camera surveillance as it is practiced today, and because even in the regime proposed here discretion as to whom to target is considerable, significant potential for discrimination exists. Indeed, research in the United Kingdom indicates that bias against minority groups is

360 Id.

361489 U.S. 656 (1989).

Von Raab, 489 U.S. at 672 n. 2 (citing Delaware v. Prouse, 440 U.S. 648, $657(1979))$.

${ }^{363}$ Wyman, 400 U.S. 309, 320-21 (1971).

364 See, e.g., United States v. Knights, 122 S. Ct. 587, 591-92 (2001)("The probation order [allowing suspicionless searches of probationers] clearly expressed the search condition and Knights was unambiguously informed of it"); United States v. Biswell, 406 U.S. 311, 316 (1972)(in holding that warrantless, suspicionless searches of gun dealers are permissible, stating "[w]hen a dealer chooses to engage in this pervasively regulated business and to accept a federal license, he does so with the knowledge that his business records, firearms, and ammunition will be subject to effective inspection."). 
widespread among camera operators. Norris and Armstrong report, for instance, that the CCTV practices they observed involved a "massively disproportionate targeting of young males, particularly if they are black or visibly identifiable as having subcultural affiliations. ${ }^{m 65}$ This differentiation, they concluded, was "not based on objective behavioural and individualised criteria, but merely on being categorised as part of a particular social group."366

Such practices are probably unconstitutional. In Whren $v$. United States, ${ }^{367}$ for instance, the Supreme Court signaled that searches and seizures that result from intentional racial discrimination could violate the Fourteenth Amendment's equal protection clause. ${ }^{368}$ Although proof of such intent is notoriously difficult, ${ }^{369}$ every step possible should be taken to assure that, in the words of the ABA Standards, "[t]he subjects of the surveillance [are] not ... selected in an arbitrary or discriminatory manner. ${ }^{\text {370 }}$

\section{Termination of the Surveillance}

The final execution issue that might trigger constitutional analysis concerns the termination of individual surveillance. The Supreme Court has emphasized the importance of durational limitations in many of its decisions defining the scope of the Fourth Amendment. In upholding the checkpoints in Marti-

ses NORRIS \& ARMSTRONG, supra 44, at 150.

366 Id. They also reported that $30 \%$ of targeted surveillances on black people, but only $13 \%$ of targeted surveillances on whites, lasted nine minutes or more, $i d$., and that blacks, teens and males were much more likely to be targeted for "no obvious reason" compared to other groups. Id. at 113-16 (Tables 6.5, 6.7, $6.9)(68 \%$ of blacks, compared to $35 \%$ of whites; $65 \%$ of teens, compared to $38 \%$ of ages 20-29; and 21\% of ages 30-39; $47 \%$ of males, compared to $16 \%$ of females were targeted for "no obvious reason").

s67 517 U.S. 806 (1996).

ses Whren, 517 U.S. at 813 ("We of course agree with petitioners that the Constitution probibits selective enforcement of the law based on considerations such as race.").

${ }^{369}$ See generally, David A. Harris, When Success Breeds Attack: The Coming Backlash Against Racial Profiling Studies, 6 Mich. J. RACE \& L. 237 (2000)(detailing difficulties of proving violations of anti-discrimination laws).

370 ABA STANDARDS, supra note 16, at 12 (Standard 2-9.1(d)(i)). 
nez-Fuerte, it pointed out that the initial stop was extremely brief and that the secondary documentary check lasted only about five minutes. ${ }^{371}$ In Sitz as well it found the initial stop, which averaged twenty-five seconds, to be a "minimal" intrusion, as "measured by the duration of the seizure and the intensity of the investigation.. ${ }^{372}$ The Court has also suggested, in United States $v$. Sharpe, ${ }^{373}$ that stops based on reasonable suspicion should not last longer than fifteen minutes or twenty minutes in the absence of extenuating circumstances. ${ }^{374}$

When it comes to CCTV, these cases suggest that, in the ABA's language, the "surveillance should be limited to its authorized objectives and be terminated when those objectives are achieved." ${ }^{m 75}$ And these cases could be mined for even more specific guidelines. Parallel to Martinez-Fuerte and consistent with the discussion concerning individualization of surveillance, camera operators could be required to terminate surveillance of a particular individual after five minutes unless reasonable suspicion develops. ${ }^{376}$ In cases where such suspicion develops they could be required, parallel to Sharpe, to cease surveillance if probable cause doesn't develop within the next fifteen minutes, unless extenuating circumstances are present. These rules would have significant impact, since research indicates

${ }^{371}$ Martinez-Fuerte, 428 U.S. at 546-47.

s72 Sitz, 496 U.S. at 444.

s73 470 U.S. 675 (1985).

s74 Sharpe, 470 U.S. at 686 . Although the Court firmly rejected a bright-line 20-minute limitation on Terry stops as "clearly and fundamentally at odds with our approach in this area," id. at 686, it went on to justify the 20-minute stop in Sharpe on the ground that the defendant's evasions were in part responsible for the delay, and in part on the ground that the officer made diligent efforts to expedite the detention. Id. at 686-87.

s75 ABA STANDARDS, supra note 16, at 12 (Standard 2-9.1(d)(ii)).

376 One objection to this rule is that, once made known to the citizenry (see infra text accompanying notes 415-16), it will be manipulated by perpetrators who will simply wait five minutes before engaging in any suspicious activity. However, the five-minute period need not start when the subject enters the camera area (and in fact shouldn't start at all unless something suspicious occurs, see supra text accompanying notes 347-57), which can be made clear in the rule disseminated to the public. Such a rule could simply read: "Camera operators will not focus on individuals unless they engage in activity indicative of criminal intent or are in need of aid, and will not continue surveillance unless criminal intent or harm is confirmed." 
that CCTV surveillance can last well over five minutes even in cases where no deployment or arrest results. ${ }^{377}$

\section{Storage and Dissemination of Recordings}

A principal feature of CCTV that distinguishes it from ordinary, non-technological surveillance is the capacity to record observations. That capacity, plus the potential for abuse of the information so generated, is apparently of major concern to the public. The British survey quoted earlier indicated that many of the people questioned were very worried about misuse of the images recorded on CCTV, ${ }^{378}$ an anxiety that is wellfounded. ${ }^{379}$ In the study conducted for this article, the scenario in which the tapes are not destroyed and instead are made available to the media and other government agencies "as needed" received a much higher intrusiveness rating $(M=73)$ than the scenario in which tapes are destroyed within 96 hours $(\mathrm{M}=53)^{380}$ Indeed, the former rating is statistically indistinguishable from the ratings associated with a body cavity search at the border and search of a bedroom, actions which require probable cause.

The Supreme Court has never addressed this particular type of privacy invasion as a Fourth Amendment matter. It came close in Wilson $v$. Layne, ${ }^{381}$ where it held that the Fourth Amendment was violated by a "media ride-along" in

s7 Norris \& Armstrong found that somewhere around $12 \%$ to $15 \%$ of all targeted surveillances lasted over nine minutes (although that percentage increased to $25 \%$ for blacks), and that close to $40 \%$ lasted between two and six minutes. NORRIS \& ARMSTRONG, supra note 44, at 150 . Deployment resulted in only $5 \%$ of targeted surveillances, and arrest occurred in only $24 \%$ of deployments. Id. at 168.

378 See supra text accompanying note 264-67 (showing, inter alia, that $72 \%$ believed that cameras "could easily be abused and used by the wrong people").

${ }^{370}$ See Blackmail Concern as CCTV Video Sex Footage Goes on Sale, THE HERALD (Glasgow), Nov. 27, 1995, at 5 (recounting sale of CCTV clips and public release of tapes showing a prostitute providing oral sex to a businessman and a man in a Santa hat stripping and then masturbating); WILLIAM G. STAPLES, EVERYDAY SURVEILLANCE: VIGILANCE AND VISIBIITY IN POSTMODERN LIFE 61-62 (2000)(describing the "potential market for tapes," and the high sales of the "Caught on Tape" and "Really Caught on Tape" videos).

${ }^{380}$ See supra Table 1, supra p. 277.

s81 526 U.S. 603 (1999). 
which a newspaper reporter and photographer accompanied police on a search of a house. There, however, the issue was solely whether the presence of the media at the time of the search was unconstitutional; because the ride-along was not "in aid" of the search's execution, it unconstitutionally infringed on the privacy of the search's target. ${ }^{382}$ Layne did not address the lawfulness of later dissemination of information about the search, whether acquired by the media at the time it occurs or from police at some later point. In the CCTV context, then, Layne at most would ban the media and other non-law enforcement entities from being present during the surveillance.

Other Supreme Court decisions, however, suggest the Constitution requires law enforcement to keep a tight rein on information it accumulates. In Whalen $v$. Roe, ${ }^{383}$ the Court considered a Fourteenth Amendment privacy challenge to a state statute that required physicians to submit information about patients' drug use to a state agency. Although the Court upheld the statute, it made much of the state's efforts to maintain security over the information submitted and the fact that the records were destroyed after five years. ${ }^{384}$ At the end of its opinion, it also noted "the threat to privacy implicit in the accumulation of vast amounts of personal information in computerized data banks or other massive government files," and stated that "in some circumstances" a "duty to avoid unwarranted disclosures ... arguably has its roots in the Constitution. ${ }^{\text {} 385}$ Citing Whalen, the Court in Ferguson $v$. City of Charleston concluded that " $[t]$ he reasonable expectation of privacy enjoyed by the typical patient undergoing diagnostic tests in a hospital is that the results of those tests will not be shared with non-

360 Wilson, 526 U.S. at 614.

389429 U.S. 589 (1977).

394 Whalen, 429 U.S. at 601 ("There is no support in the record, or in the experience of the two States that New York has emulated, for an assumption that the security provisions of the statute will be administered improperly."). The Court also noted that it did not need to address the constitutionality of "the unwarranted disclosure of accumulated private data whether intentional or unintentional or by a system that did not contain comparable security provisions." Id. at 605-06.

38s Id. at 605 . 
medical personnel without her consent." ${ }^{\text {s86 }}$ Also relying on Whalen, the Court in Department of Justice v. Reporters Committee for Freedom of the Press stated that "the fact that an event is not wholly 'private' does not mean that an individual has no interest in limiting disclosure or dissemination of the information. ${ }^{\text {387 }}$ That case went on to hold that, under the Freedom of Information Act (FOIA), government-maintained rap sheets on criminals need not be disclosed to the press because they did not further the FOIA's "central purpose" of exposing to public scrutiny official information that sheds light on an agency's performance of its statutory duties. ${ }^{388}$

These cases indicate that the Court is willing to interpret the Constitution and statutory mandates to circumscribe disclosure of private information gathered by the government. In the CCTV setting, the content of these rules might vary widely. With respect to storage of information, a jurisdiction might require that all recordings not relevant to a criminal investigation be destroyed within a short period of time (the ninety-six hour limitation used in the survey reported in this article comes from Baltimore's policy ${ }^{389}$ ). Or it could opt for a much longer maintenance period, in the belief that the usefulness of particular tapes, either to inculpate or exculpate, may not become apparent until significant time has elapsed. The important feature here is to ensure the security of the recordings. With respect to dissemination, the Court's cases suggest that allowing information to be used for non-law enforcement purposes ought to be permitted only under compelling circumstances, if at all. The ABA Standards recommend that "disclosures be prohibited unless affirmatively authorized by statute, judicial decision or agency rule. ${ }^{\text {} 390}$ That language echoes the Sitz mandate that decisions affecting large segments of the public

588532 U.S. 67,78 \& n.14 (2001).

387489 U.S. 749,770 (1989).

${ }^{283}$ Reporters Comm., 489 U.S. at 774.

${ }^{389}$ See Remarks of Stephen McMahon, supra 68, at 6.

390 ABA STANDARDS, supra note 16, at 13 (Standard 2-9.1(d)(vi)(comment). See Harold J. Krent, Of Diaries and Data Banks: Use Restrictions Under the Fourth Amendment, 74 TEX. L. REv. 49, 85-92 (1995)(giving reasons for requiring disclosure rules to be promulgated by deliberative bodies). 
be left to politically accountable officials.

Before leaving this subject, mention must be made of a provocative proposal made by William Stuntz. I have argued here that, in addition to rules regarding disclosure, we need rules concerning justification and implementation. Stuntz suggests that, at least when government engages in "secret searches," we might profitably consider focusing solely on disclosure rules. $^{391}$ More specifically, he proposes that government be allowed to carry out such searches randomly, without having to demonstrate any suspicion, on condition that it be permitted to use the information it obtains only in prosecutions for serious, violent crimes. ${ }^{392}$ That approach, he asserts "would allow us to give both the police and private citizens more of what they value-easier evidence-gathering and reduced risk of embarrassment or harassment."

Although CCTV, as defined in this article, is not conducted secretly, it could be. ${ }^{394}$ Stuntz would allow such covert use at the whim of the police, as long as the disclosure rule is followed. No one would know their right to anonymity had been invaded unless and until they are prosecuted for a serious crime. Why not institute this regime rather than bother with the elaborate rules discussed to this point?

One concern is whether government can be trusted to limit its use of the information it obtains through covert CCTV to prosecutions of serious crimes. Given the secret nature of these searches, finding the "poisonous tree" in prosecutions for nonserious crimes may be difficult. ${ }^{395}$ Furthermore, of course,

s91 William J. Stuntz, Local Policing After the Terror, 111 Yale L.J. 2137, 2183-84 (2002)("The law could allow a given search tactic whenever the police want to engage in it, but forbid public disclosure of anything uncovered save in a criminal trial.")

${ }^{392}$ Id. at 2184.

393 Id. at 2185.

394 See UPI, supra note 54 (describing new CCTV system in Hull, England "using tiny cameras disguised in street lamps or concealed on buildings to transmit pictures to a monitoring center around the clock.")

996 Informants can always be manufactured when necessary to cover illegal investigation practices. See Christopher Slobogin, Testilying: Police Perjury and What To Do About It, 67 U. CoLo. L. REv. 1037, 1043 n. 28 (1996)(discussing "the invention of 'confidential informants' . . . , a ploy that allows police to cover up irregularities in developing probable cause or to assert they have probable 
barring use of surveillance results in court does not provide any disincentive to police who intend to use CCTV feeds solely to harass "flawed consumers" or take other actions they know will not lead to charges being filed. ${ }^{396}$

The more important problem with the elimination of justification and execution rules, however, has to do with the right to anonymity. Stuntz' proposal might not openly infringe that right for those not prosecuted, but it insidiously trenches on everyone's right to avoid suspicionless government scrutiny. Indeed, in the CCTV context, once the public becomes aware that random covert surveillance is occurring, as it inevitably would after a few prosecutions in which the covertly gleaned information is used, the panoptic effect of this regime will be greater than occurs with overt CCTV. Although the survey results reported earlier suggest otherwise (with the covert scenario ranked significantly lower than the overt scenar${ }{ }^{397}$ ), the covert scenario used in the survey implied that the surveillance was limited to one location. ${ }^{998}$ In Stuntz' society, by contrast, we would assume that secret surveillance was pervasive, not just incidental. That would move us one step closer to an Orwellian society, because we would no longer know when and where government is attempting to find out what we are doing in public; in other words, we would not know when or how to protect against invasion of our public anonymity. Probably no passage in Orwell's novel 1984 is more chilling than the one partially excerpted at the beginning of this article: "There was of course no way of knowing whether you were being watched at any given moment. . . . It was even conceivable that they watched everybody all the time. ${ }^{399}$

\footnotetext{
cause when in fact all they have is a hunch.")

${ }^{396}$ See infra note 408-09 and accompanying text.

s9r See Table 1 (covert scenario $(M=42)$; overt scenario $(M=53)$ ), supra p. 277.

sse Specifically, the scenario read as follows: "Police at a central control center monitoring hidden video cameras positioned at 300-yard intervals that can zoom in on the face and body of a person." Survey form, supra note 274.

s99 ORWELL, supra note 3 , at 6 .
} 


\section{Accountability}

Even overt CCTV can be covert in the sense that we may not know precisely when publicly placed cameras are being used to watch us, or for how long, or with what level of justification, if any. And if we do not have that information, the rules described above cannot be enforced. Even with that information, reliance on the police to hold themselves accountable for a violation of the rules, which is the current approach, is unlikely to ensure full compliance. Finally, even good faith efforts at full compliance with the rules will not achieve their ultimate goal as long as people still feel significant panoptic effects. Unless people believe they are free from camera observation most of the time they are in public, constitutionalizing police use of CCTV does not do much good. All three of these concerns deserve some attention.

\section{Watching the Watchers}

The rules concerning individualization, discrimination and termination comprise what could be called "conduct-of-surveillance" rules, since they have to do with the actual operation of the cameras. How can we know when camera operators are scrutinizing a particular individual for a prolonged period of time despite a lack of articulable suspicion? How do we make sure that the police refrain from using cameras in a discriminatory fashion?

Self-reports probably will not work. Operators may not even recognize their discriminatory practices, and if they did, they are hardly likely to confess them. Similarly, suspicion is always easy to manufacture in hindsight, if the searcher has control of the facts..$^{40}$ As the ABA Standards admonish, police must develop "administrative rules which ensure that the information necessary for ... accountability exists, ${ }^{n 401}$ a sentiment

${ }^{400}$ See William J. Stuntz, Warrants and Fourth Amendment Remedies, 77 VA. L. REv. 881, 913-15 (1991)(discussing the ease with which police can commit perjury at suppression hearings, given their ability to reconstruct what happened based on knowledge of what was found, the tendency to believe police rather than criminal defendants, and the hindsight biasing effect created by arrest).

401 ABA STANDARDS, supra note 16, at 13 (Standard 2-9.1(f)(i))(emphasis add- 
that is not inconsistent with Fourth Amendment tenets. ${ }^{402}$

David Brin has argued that the best way to control the government (and everyone else) in a surveillance-happy "transparent society" is to watch the watchers. ${ }^{403}$ That idea could be implemented in the CCTV context in at least two ways. Camera tapes could be "audited" periodically and randomly by independent reviewers to determine whether operators are violating any of the rules. Or the watchers really could be watched, by cameras. That method would not only capture the facts necessary to determine whether conduct of surveillance standards are obeyed, but also bring home to operators the panoptic effects their surveillance has on others, thus perhaps curbing voyeuristic and other unnecessary observation.

\section{Assuring Compliance}

Assuming a violation is discovered, what should be done? As noted earlier, police favor "voluntary guidelines," by which they appear to mean rules that they not only develop, but also enforce. The history of police willingness to punish their own for violations that involve balancing abstract concepts like "privacy" against law enforcement needs is well-known and not impressive. ${ }^{404}$ Some other accountability mechanism is neces-

ed).

102 The Supreme Court has indicated that the failure to maintain accurate records about the result of a search is not a violation of the Fourth Amendment when the underlying search is valid. Cady v. Dombrowski, 413 U.S. 433, 449 (1973)("As these items were constitutionally seized, we do not deem it constitutionally significant that they were not listed in the return of the warrant."). But it has yet to address this issue where the validity of the search is questionable or indeterminable because of police failure to provide adequate information. Furthermore, it has held that the Fourth Amendment is violated when police intentionally hide or mischaracterize information relevant to a search. Franks v. Delaware, 438 U.S. 154, 155-56 (1978)("where the defendant makes a substantial preliminary showing that a false statement knowingly and intentionally, or with reckless disregard for the truth, was included by the affiant in the warrant affidavit, and if the allegedly false statement is necessary to the finding of probable cause, the Fourth Amendment requires that a hearing be held at the defendant's request").

${ }^{403}$ David Brin, The Transparent Society (1998).

404 See generally Christopher Slobogin, Criminal Procedure: Regulation of Police INVESTIGATION 563-65 (2d ed. 1998)(describing ineffectiveness of adminis- 
sary.

In the Fourth Amendment context, that mechanism has usually been exclusion of illegally obtained evidence. ${ }^{405}$ Certainly that sanction should be invoked when it applies. But it is unlikely to be a potent deterrent in connection with the types of rules at issue here.

Take first the rules concerning individualization, discrimination and termination-the conduct-of-surveillance rules. The most important reason exclusion does not do a good job encouraging compliance with these types of rules is that the vast majority of people subject to camera surveillance, and therefore most people whose activities are observed in violation of the rules, will never be prosecuted, either because they are completely innocent or commit infractions that are taken care of on the street. ${ }^{406}$ In short, most violations of the right to public anonymity will not be redressed through exclusion. That is not a good prescription for ensuring deterrence. ${ }^{407}$

Moreover, when police do want to prosecute crimes illicitly discovered through camera surveillance, they will frequently be able to avoid exclusion. First, exclusion may not be required if the field officer who makes an arrest based on information from a camera operator acts in a good faith belief that no rules were violated by the operator. ${ }^{408}$ Second, police know that if they can track down eyewitnesses, through the camera tapes or

trative sanctions); JEROME SKOLNICK, JUSTICE WITHOUT TRIAL 224 (1975)(asserting that as long as a search or seizure is in conformity with administrative norms of police organization," superiors will be sympathetic).

${ }^{405}$ Mapp v. Ohio, 367 U.S. 63 (1961).

206 See NORRIS \& ARMSTRONG, supra note 44, at 168 (reporting that arrests resulted from only 12 , or $1.2 \%$, of 986 "targeted surveillances," and that police deployed by cameras gave "no more than a warning" to $76 \%$ of those confronted by police); see also Norris, supra note 51, at 37 (noting that exclusion of unwanted individuals in CCTV regimes "is achieved without any recourse to the formal criminal justice system and therefore bypasses legal safeguards embodied in the public justice of the courts").

${ }_{407}$ Behavioral theory suggests that unwanted behavior is most likely to be eliminated if punishment occurs immediately after every unwanted incident. See Christopher Slobogin, Why Liberals Should Chuck the Exclusionary Rule, 1999 ILL. L. REv. 363, 374-377 (applying behavioral theory to exclusionary rule).

100 See Arizona v. Evans, 514 U.S. 1 (1995)(holding that exclusion is not required where arresting officer relies on computer records maintained by civilian court personnel). 
otherwise, the latter's testimony will usually be admissible even if the testimony of the camera operator and field officer is tainted by illegal surveillance. ${ }^{409}$ Only if the prosecution of crimes were barred outright whenever they are discovered through a violation of CCTV rules would the threat of "exclusion" pose a serious deterrent. But even then, resourceful operators can hide the poisonous tree through untracked calls to a field officer.

As a supplement to exclusion, a more direct sanction is necessary when conduct-of-surveillance rules are violated. In theory, both damages actions and administrative and criminal sanctions are far superior to exclusion, because they would not be dependent on whether prosecution-or indeed on whether any government action at all-is based on surveillance results. Criminal prosecutions would probably be considered too draconian or too difficult to bring, however. ${ }^{410}$ Given the many limitations on constitutional damage actions that have been imposed by the courts, ${ }^{411}$ that method of deterring violations would not work well either, at least as it is currently structured. ${ }^{412}$ The best sanctioning system may well be an administrative penalty, such as a suspension or a dock in pay, but sought by an entity independent of the police and enforced by the courts. ${ }^{413}$

${ }^{109}$ Cf. United States v. Ceccolini, 435 U.S. 268, 278 (1978)(holding that since witnesses would often come forward of their own accord, and "since the cost of excluding live-witness testimony often will be greater, a closer, more direct link between the illegality and that kind of testimony is required" before exclusion of the witness will occur).

${ }^{10}$ See Whitebread \& Slobogin, supra note 317, at 61-62 (describing obstacles to criminal prosecutions for Fourth Amendment violations).

11 Suits under 42 U.S.C. $\$ 1983$, the main avenue for constitutional damage actions, would not be worth the effort for many people who are illegally surveilled because actual injury in such cases would be negligible, and "symbolic" injury is not compensable. Memphis School Dist. v. Stachura, 477 U.S. 299 (1986). Further, unless the violation is somehow ratified by a superior, the government would usually have a "policy or custom" defense. Pembaur v. Cincinnati, 475 U.S. 469 (1986).

412 I have suggested methods of significantly reforming the damage regime to make it a more effective deterrent. See Slobogin, supra note 407, at 384-390.

${ }^{413}$ An ombudsman could both conduct the audits and initiate the disciplinary proceedings. Cf. Robert P. Davidow, Criminal Procedure Ombudsman Revisited, 73 
The other three rules proposed above concern camera placement, notice of camera placement, and disclosure of recordings. Here again the exclusionary sanction is not a particularly good fit. If the placement or notice rules are violated, exclusion of all evidence garnered through the subsequent surveillance seems like overkill if the other rules are followed, and in any event would not necessarily stop surveillance aimed at "flawed consumers." And unlawful disclosure to non-law enforcement entities does not even involve a proceeding at which evidence can be excluded. For the first two types of violations, it would probably be preferable to seek an injunction ordering installation to desist or notice to be provided, which courts could grant when politically accountable officials fail to provide any "reasonable" explanation for their decision. ${ }^{414}$ In the latter instance, damages remedies are probably more feasible than in other settings, ${ }^{415}$ although judicially-backed administrative sanctions are probably necessary as well.

\section{Beyond Sanctions: Accountability Through Information}

Will any of this do any good? After all, cameras will still be lawfully installed in some locations. In those areas, won't people still feel "watched," regardless of whether the conduct-ofsurveillance and disclosure rules are followed? If so, why bother with all of these rules?

These are good questions. At most, the panoptic effects of

\section{J. CrIm. L. \& Criminology 939 (1982).}

414 Hague v. C.I.O., 307 U.S. 496 (1939)(holding that a state official may be enjoined under $\S 1983$ ). Because the issue concerns whether a planned CCTV system may be installed, it is justiciable; the Court's rigid barriers to injunctive relief against discretionary decisions, see e.g., Los Angeles v. Lyons, 461 U.S. 95 (1983), would be avoided.

415 If dissemination of the tape is widespread, damages are less likely to be negligible. Cf. supra note 411 and accompanying text. Although a constitutional damages suit against the government might be stalled by a policy and custom defense, see supra note 411 , and the party that receives the tape may be immune, see Bartnicki v. Vopper, 532 U.S. 514 (2001), the individuals who release the tape are still liable. Of course, a state law tort action, based on public disclosure of private facts, may also be available. See RESTATEMENT (SECOND) OF TORTS \$652C (1977); RESTATEMENT (THIRD) OF THE LAW OF UNFAIR COMPETTTION $\S 46$ (1993)(nonconsensual appropriation of name of likeness for commercial purposes is actionable). 
lawfully placed cameras can only be mitigated, not eliminated. To ensure as much of this mitigation as possible, the conductof-surveillance rules should be promulgated widely, and any sanctions imposed as a result of their violation should be publicized as well.

Two other proposals, both recommended by the ABA, are worth consideration. First, "periodic review of the scope and effectiveness of [the] surveillance" ought to occur. ${ }^{416}$ Second, the government should "maintain [ and mak[e] available to the public general information about the type or types of surveillance being used and the frequency of their use. ${ }^{\text {417 }}$ Right now, most police departments take neither of these steps. ${ }^{418}$ That should be rectified. Periodic internal review would ensure that the government pays attention to whether the cameras are achieving the crime reduction goal it seeks, and might even result in the disassembly of some cameras. Review will also provide information about the nature, frequency and success of camera surveillance that can be disseminated to the public, which can then reach its own conclusions about the scope of surveillance.

Ideally, dissemination of information about CCTV that is conducted under the rules proposed here will lead to the realization that most of us are of no interest to camera operators. Fear that our public actions, or images of those actions, will be scrutinized by faceless bureaucrats or government agents with a suspect agenda should be allayed. Similar to what occurred in connection with electronic surveillance after the advent of legislation requiring strict judicial control over and disclosure of government wiretapping and bugging practices, ${ }^{419}$ we should be able to rest assured that camera operators will not watch us simply because they can.

The constitutional basis for these review and publication

11 ABA STANDARDS, supra note 16, at 13 (Standard 2-9.1(f)(iv)).

117 ABA STANDARDS, supra note 16, at 13-14 (Standard 2-9.1(f)(v)).

11 Recall that $96 \%$ of the departments surveyed by the IACP do not maintain information about the effectiveness of their use of CCTV. See supra note 80.

11918 U.S.C. $\S 2529(3)$ (requiring periodic reports of number of surveillance warrants and warrant extensions, types of crimes investigated with surveillance, number of people overheard, arrests generated by surveillance, and so on). 
rules is again the Fourth Amendment. After all, that Amendment guarantees a right to be "secure" from unreasonable searches and seizures. ${ }^{420}$ Knowledge that government has enacted rules limiting its surveillance powers, that the rules are being enforced, and that periodic reports on the implementation and success of the surveillance will be made public is the surest way to enhance a sense of security in an age when technology threatens our anonymity.

\section{CONCluding COMMENTS: A DIFFERENT FOURTH AMENDMENT?}

The fundamental question addressed in this article is whether government use of cameras to observe the public activities of its citizens is a concern of constitutional dimension. CCTV might implicate several constitutional doctrines, among them the First Amendment, the right to freedom of movement, and the general right to privacy. But if one provision has to be selected as a constitutional basis for regulating this type of surveillance, it should probably be the Fourth Amendment, the primary source of limitations on police investigative techniques.

Admittedly, the Supreme Court's Fourth Amendment caselaw does not form a solid basis for the conclusion that CCTV constitutes a "search" or "seizure." Yet, as a linguistic matter, once camera operators shift from scanning crowds to targeting individuals, they are certainly engaging in a "search," the narrowest definition of which involves looking "into or over carefully or thoroughly in an effort to find or discover something. ${ }^{\text {421 }}$ A less literal reading of the Fourth Amendment's threshold should even more readily lead to the same result. Whether framed in the Court's language-in terms of expecta-

620 See generally, Clancy, supra note 255; see also, McAdams, supra note 139:

[T]he amendment guarantees the people a right to be 'secure,' a word that means 'free from fear, care, or anxiety: easy in mind . . . having no doubt.' Manifestly concerned with the repose of the people, the framers of the Fourth Amendment did not merely create a right of individuals to be free from unreasonable searches or seizures, but a societal right to be free from the fear such practices create.

McAdams, supra note 139 , at 318-19.

231 WeBSTER's COLlegIATE DictionaRY, supra note 113, at 1042. 
tions of privacy society is prepared to recognize as reasonable-or in mine-in terms of a right to anonymity that protects against unnecessary government scrutiny-that threshold is crossed when government trains cameras on its citizens, because of the panoptic atmosphere such surveillance creates (an atmosphere that the empirical research reported here suggests is more intrusive than many other government actions that are clearly governed by the Fourth Amendment). If the federal constitution cannot be read to place restrictions on CCTV, then state constitutions, which are less encumbered with negative precedent, should be so construed. ${ }^{422}$

The same approach should be taken toward other large scale or targeted use of technology by the government, whether it involves monitoring beepers or email traffic, use of computers or satellites. Close examination of an individual's affairs, even those that take place in public venues, ought be regulated to ensure government intrusion into our lives does not grow with technological developments. "Dragnet law enforcement practices," to use Knotts' terminology, should be the province of the Fourth Amendment. ${ }^{423}$

The usual implication of this kind of conclusion is that the government must demonstrate probable cause before it can act. Outside of the special needs/administrative context and frisks, the Supreme Court has continued to adhere to that relatively high justificatory standard for searches. ${ }^{424}$ Yet that stance either effectively forecloses most law enforcement practices using largescale surveillance or, conversely, provides a huge incentive to leave them entirely unregulated, the Court's usual choice in related settings. ${ }^{425}$ If rules of the type devised in this article

${ }^{422}$ See Burrows, supra note 56, at 1114-1122 (discussing state constitutional provisions on which regulation of CCTV might be based).

${ }^{423}$ Compare Daniel J. Solove, Digital Dossiers and the Dissipation of Fourth Amendment Privacy, 75 S. CAL. L. REv. 1084, 1156 (2002)(arguing that courts should recognize a difference, for Fourth Amendment purposes, between information obtained "by speaking with specific individuals versus obtaining it through the vast stores of records held by companies").

124 Ferguson v. City of Charleston, 532 U.S. 67, 88 (2001)(Kennedy, J., concurring)("The traditional warrant and probable-cause requirements are waived in our previous cases on the explicit assumption that the evidence obtained in the search is not intended to be used for law enforcement purposes").

${ }^{425}$ See Christopher Slobogin, The World Without a Fourth Amendment, 39 
are to be adopted as a constitutional matter, the "probable cause forever" standard must be abandoned. ${ }^{426}$

Likewise, dependence on the exclusionary rule as the dominant means of enforcing the Fourth Amendment can stultify meaningful oversight. Never a particularly powerful deterrent even in the traditional search and seizure setting, ${ }^{427}$ the rule is even less useful when surveillance of large numbers of people, most of whom will never be prosecuted, is the investigative technique to be regulated. If prevention of violations is the goal, the "punishment" ought to better fit the "crime."

The proposals made here, which are meant to be general in nature to allow the democratic process to fill in the details, reflect those insights. Neither the placement of cameras nor intense scrutiny of particular individuals would require probable cause (or a warrant), but politically accountable officials would have to demonstrate solid grounds for the first action, and camera operators would have to have articulable suspicion for the second. Rules governing storage and disclosure of recordings, which can come under either the Fourth or Fourteenth Amendment's purview, would no longer be secondary to cause requirements but assume central importance as a means of protecting privacy. Depending on the rule in question, administrative sanctions, injunctions and damages should be considered as a supplement to, or substitute for, exclusion as a means of assuring compliance, and dissemination of information about the rules and the use of surveillance ought to be considered as still another way of vindicating the Fourth Amendment guarantee of security from unreasonable searches.

Something akin to these proposals should also be applicable to other types of large-scale technological surveillance conducted by the government. Panopticism comes in many forms. In this era of rapid technological change, the freedom to be unnoticed in public, and its associated benefits, will disappear

UCLA L. REV. 1, 77 (1991)(“Because the courts have been unwilling to define probable cause in this adaptable way, the warrant requirement is slowly being read out of the amendment and many types of searches and seizures are unregulated."). See also, Slobogin, supra note 269, at 1072-73.

${ }^{128}$ See Slobogin, supra note 269 , at 1081-91.

127 See Slobogin, supra note 407, at 373-84. 
unless a right to public anonymity is recognized and enforced. 
HeinOnline -- 72 Miss. L.J. 316 2002-2003 